\title{
EVALUASI FUNGSI EKOLOGIS JALUR HIJAU JALAN KAWASAN SENTUL CITY, BOGOR
}

\section{ANITA DESIANTI}

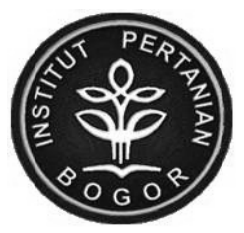

\author{
DEPARTEMEN ARSITEKTUR LANSKAP \\ FAKULTAS PERTANIAN \\ INSTITUT PERTANIAN BOGOR \\ BOGOR




\title{
PERNYATAAN MENGENAI SKRIPSI DAN SUMBER INFORMASI
}

\author{
Dengan ini, saya menyatakan bahwa skripsi yang berjudul Evaluasi Fungsi \\ Ekologis Jalur Hijau Jalan Kawasan Sentul City, Bogor adalah benar merupakan \\ hasil karya sendiri dan belum diajukan dalam bentuk apapun kepada perguruan tinggi \\ manapun. Semua sumber data dan informasi yang berasal atau dikutip dari karya \\ yang diterbitkan maupun yang tidak diterbitkan dari penulis lain, telah disebutkan \\ dalam teks dan dicantumkan pada Daftar Pustaka skripsi ini.
}

Bogor, Maret 2011

ANITA DESIANTI

A44060260 


\section{RINGKASAN}

\section{ANITA DESIANTI. Evaluasi Fungsi Ekologis Jalur Hijau Jalan Kawasan Sentul City, Bogor. Dibimbing oleh ALINDA F.M ZAIN.}

Peningkatan jumlah penduduk berakibat pada meningkatnya kebutuhan lahan untuk tempat tinggal. Terbatasnya lahan pada perkotaan mendukung terbentuknya kawasan-kawasan pendukung di daerah sekitar kota, yang disebut kota satelit. Sentul City merupakan salah satu kota satelit yang berada di wilayah kabupaten Bogor.

Jalan merupakan elemen yang penting bagi kota sebagai akses untuk masuk, penghubung antar kawasan, dan jalur pergerakan orang dan barang. Jalan pada kawasan perkotaan umumnya ditandai dengan lalu lintas yang padat dan tingkat polusi yang tinggi. Kawasan permukiman Sentul City saat ini memiliki kawasan yang sudah terbangun kurang lebih $40 \%$. Pada kondisi ini, pergerakan kendaraan masih tergolong rendah. Namun, terdapat potensi terjadinya peningkatan jumlah kendaraan seiring berkembangnya kawasan. Peningkatan jumlah kendaraan merupakan salah satu penyebab peningkatan pencemaran udara, terutama pada jalan.

Dampak pencemaran dapat diatasi salah satunya dengan penyediaan ruang terbuka hijau. Untuk jalan, bentuk ruang terbuka hijau berupa jalur hijau jalan. Pada lanskap jalan utama kawasan Sentul City, yaitu jalan MH Thamrin dan jalan Siliwangi, sudah dilengkapi taman dan mendapatkan rekor MURI sebagai taman terluas pada jalan utama. Hal ini menunjukkan bahwa taman atau jalur hijau jalan utama dinilai sudah memadai dan memenuhi kriteria estetis. Jalur hijau jalan sudah estetis namun apakah jalur hijau jalan tersebut sudah memenuhi fungsi ekologis perlu diketahui lebih lanjut. Karena itu, dilakukan evaluasi terhadap fungsi ekologis jalur hijau jalan dalam menyerap polutan gas dan menjerap partikel.

Penelitian dilakukan pada jalan utama kawasan yaitu jalan $\mathrm{MH}$ Thamrin. Evaluasi yang dilakukan pada penelitian ini yaitu evaluasi fungsi ekologis jalur hijau jalan sebagai penyerap polutan gas dan penjerap partikel. Penelitian dilakukan dalam beberapa tahap yaitu inventarisasi, analisis, evaluasi, dan sintesis. Pada tahap inventarisasi dilakukan pengumpulan data primer dan sekunder. Analisis yang digunakan pada penelitian ini yaitu analisis deskriptif dan spasial. Analisis deskriptif digunakan untuk mengetahui kesesuaian pohon pada jalur hijau jalan untuk fungsi penyerap polutan gas dan penjerap partikel. Penilaian untuk evaluasi fungsi ekologis jalur hijau jalan menggunakan beberapa kriteria yang didapatkan dari studi literatur. Kondisi lapang jalur hijau jalan dibandingkan dengan kriteria tersebut kemudian untuk tiap kriteria diberikan nilai antara 1 sampai 4, dan nilai ideal untuk tiap kriteria adalah 4. Hasil penilaian tersebut dikelompokkan dalam beberapa kategori berdasarkan pemenuhan kriteria yaitu tidak sesuai (<40\%), kurang sesuai $(40-60 \%)$, sesuai $(60-80 \%)$, dan sangat sesuai (>80\%). Analisis spasial digunakan dalam mengolah data spasial dan menspasialkan hasil penilaian tersebut. Hasil penilaian dianalisis spasial dengan membedakan kategori jalur hijau jalan yang tidak sesuai, kurang sesuai, sesuai, 
dan sangat sesuai. Analisis spasial dilakukan untuk mendapatkan sebaran vegetasi dan mengetahui luasannya.

Kawasan Sentul City memiliki desain kawasan yang menarik dan estetis. Desain yang estetis tersebut terlihat juga pada jalan utama kawasan, yaitu jalan MH Thamrin. Jalan MH Thamrin memiliki panjang jalan sekitar $3 \mathrm{~km}$ meliputi daerah ruang terbuka dan berawal dari simpang susun Sentul Selatan sampai gerbang Siliwangi. Jalan MH Thamrin terdiri dari dua jalur kendaraan selebar 9 meter yang dipisahkan oleh median berupa jalur tanaman selebar 12 meter. RTH jalur hijau jalan MH Thamrin berbentuk jalur dan berpola linear mengikuti bentuk jalan. Jalur hijau jalan disediakan pada bagian tepi jalan, median jalan, dan juga pada traffic island. Berdasarkan observasi lapang, pada jalur hijau jalan ini terdapat 32 jenis pohon.

Dari hasil evaluasi fungsi ekologis untuk penyerap polutan gas, jalur hijau jalan yang memenuhi kriteria untuk fungsi penyerap polutan gas kategori sangat sesuai yaitu 5 jenis pohon dengan proporsi luas 63,54\%. Kategori sesuai yaitu 11 jenis pohon dengan proporsi luas 22,67 \%. Kategori kurang sesuai yaitu 14 jenis pohon dengan proporsi luas 13,75 \%. Kategori tidak sesuai yaitu 2 jenis pohon dengan proporsi luas 0,05 \%. Dari hasil evaluasi jalur hijau jalan untuk penjerap partikel, jalur hijau jalan yang memenuhi kriteria untuk fungsi penjaerap partikel kategori sangat sesuai yaitu 2 jenis pohon dengan proporsi luas 30,99 \% dari luas jalur hijau jalan yang dipetakan. Kategori sesuai yaitu 10 jenis pohon dengan proporsi luas 39,91 \%. Kategori kurang sesuai yaitu 11 jenis pohon dengan proporsi luas 21,37 \%. Kategori tidak sesuai yaitu 9 jenis pohon dengan proporsi luas $7,73 \%$.

Setelah melakukan evaluasi kemudian dilakukan perumusan rekomendasi untuk evaluasi fungsi ekologis jalur hijau jalan pada tahap sintesis. Rekomendasi ditujukan untuk memaksimalkan fungsi ekologis jalur hijau jalan untuk fungsi ekologis yang diteliti yaitu menyerap polutan gas dan menjerap partikel.

Kata kunci : lanskap jalan, jalur hijau jalan, evaluasi, fungsi ekologis 


\section{® Hak Cipta Milik IPB, tahun 2011 \\ Hak Cipta dilindungi Undang-undang}

Dilarang mengutip sebagian atau seluruh karya tulis ini tanpa mencantumkan atau menyebutkan sumbernya. Pengutipan hanya untuk kepentingan pendidikan, penelitian, penulisan karya ilmiah, penyusunan laporan, penulisan kritik, atau tinjauan suatu masalah, dan pengutipan tersebut tidak merugikan IPB.

Dilarang mengumumkan dan memperbanyak sebagian atau seluruh karya tulis ini dalam bentuk apapun tanpa izin IPB. 


\title{
EVALUASI FUNGSI EKOLOGIS JALUR HIJAU JALAN KAWASAN SENTUL CITY, BOGOR
}

\section{ANITA DESIANTI}

\author{
Skripsi \\ Sebagai salah satu syarat untuk memperoleh gelar \\ Sarjana Pertanian pada Departemen Arsitektur Lanskap \\ Fakultas Pertanian Institut Pertanian Bogor
}

\section{DEPARTEMEN ARSITEKTUR LANSKAP FAKULTAS PERTANIAN INSTITUT PERTANIAN BOGOR BOGOR 2011}




\title{
LEMBAR PENGESAHAN
}

\author{
Judul Skripsi \\ : Evaluasi Fungsi Ekologis Jalur Hijau Jalan Kawasan \\ Sentul City, Bogor \\ Nama Mahasiswa : Anita Desianti \\ NRP \\ : A44060260 \\ Menyetujui \\ Dosen Pembimbing
}

Dr. Ir. Alinda F. M. Zain, MSi

NIP 196601261991032002

Mengetahui

Ketua Departemen Arsitektur Lanskap

Dr. Ir. Siti Nurisjah, MSLA

NIP 194809121974122001

Tanggal Lulus : 


\section{RIWAYAT HIDUP}

Penulis lahir dengan nama Anita Desianti di Jakarta pada 2 Desember 1987. Penulis merupakan anak sulung dari Itam Hari dan Siti Khoiriyah dan merupakan kakak dari Dwi Saputra.

Penulis memulai pendidikan formal sekolah dasar pada tahun 1994 di Sekolah Dasar Negeri Rawa Barat 05 dan berhasil menyelesaikan proses belajar pada tahun 2000. Di tahun yang sama, penulis melanjutkan pendidikan ke Sekolah Menengah Pertama Negeri 13 Jakarta. Penulis kemudian melanjutkan pendidikan ke Sekolah Menengah Atas Negeri 55 Jakarta pada tahun 2003 dan lulus pada tahun 2006.

Penulis melanjutkan pendidikan tinggi ke Institut Pertanian Bogor melalui jalur Undangan Seleksi Masuk IPB (USMI). Penulis menjalankan tahun pertama di universitas sebagai mahasiswa Tingkat Persiapan Bersama (TPB). Pada tahun kedua, penulis menjadi mahasiswa pada mayor Arsitektur Lanskap. Selama menjadi mahasiswa, penulis turut aktif dalam beberapa kepanitiaan acara kampus dan departemen. Penulis sempat melakukan kegiatan magang di Kebun Raya Bogor pada tahun 2008. Penulis berkesempatan menjadi asisten praktikum untuk mata kuliah Analisis Tapak pada tahun 2010. 


\section{KATA PENGANTAR}

Puji dan syukur penulis haturkan ke hadirat Tuhan Yang Maha Esa atas terselesaikannya skripsi berjudul Evaluasi Fungsi Ekologis Jalur Hijau Jalan

Kawasan Sentul City, Bogor. Penulisan skripsi tersebut merupakan syarat untuk mendapatkan gelar Sarjana Pertanian pada mayor Arsitektur Lanskap.

Pada kesempatan ini penulis ingin berterima kasih kepada berbagai pihak yang telah membantu selama proses pengerjaan skripsi, yaitu:

1. Keluarga, atas doa, pengertian dan dukungan selama penulis menjalani pendidikan sebagai mahasiswa

2. Dosen pembimbing, Dr. Ir. Alinda F.M. Zain, M.Si. atas bimbingan, kritik, dan saran selama penelitian

3. Dr. Ir. Nizar Nasrullah dan Ir. Qodarian Pramukanto, M.Si, yang telah menguji serta untuk saran perbaikan penelitian

4. Dosen pembimbing akademik, Dr. Ir. Nurhayati H.S.A, M.Sc serta seluruh dosen Departemen Arsitektur Lanskap atas ilmu dan bimbingan yang telah diberikan pada penulis selama menjadi mahasiswa Arsitektur Lanskap

5. Bapak Adrian, dari pihak Sentul City yang telah memberikan ijin penelitian, Ibu Beby dan Mas Risky dari divisi TMD yang telah banyak membantu penulis dalam pengumpulan data untuk penelitian

6. Teman-teman satu bimbingan skripsi, chanchan, mutebi, dan ami margolang, untuk kekompakan dan kebersamaan selama masa penelitian

7. Teman-teman ARL 43 atas kebersamaan selama masa kuliah serta dukungan dan bantuan selama masa penelitian

8. Semua pihak yang telah membantu terlaksananya penelitian, langsung maupun tidak langsung, yang tidak mungkin disebutkan satu persatu.

Penulis menyadari masih banyak kekurangan dari penelitian ini dan mengharapkan saran dan masukan dari berbagai pihak. Penulis berharap penelitian ini dapat bermanfaat bagi berbagai pihak.

Bogor, Maret 2011 


\section{DAFTAR ISI}

halaman

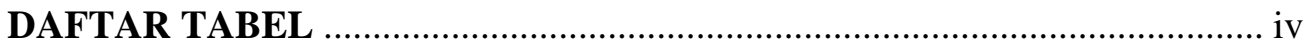

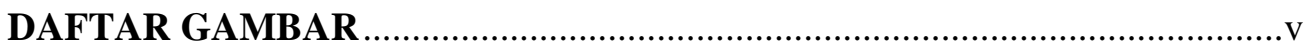

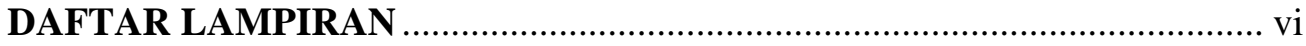

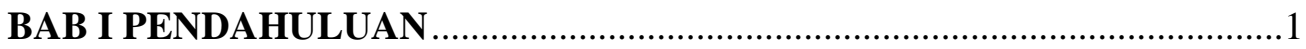

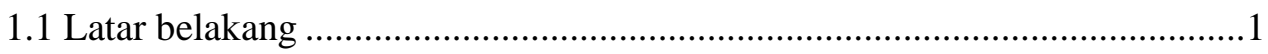

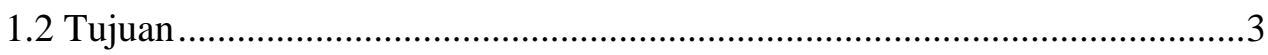

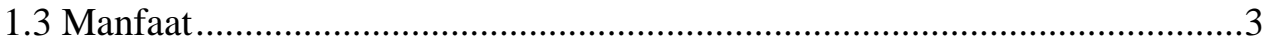

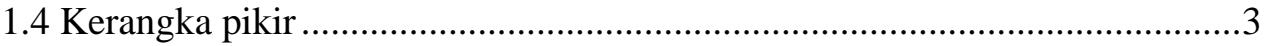

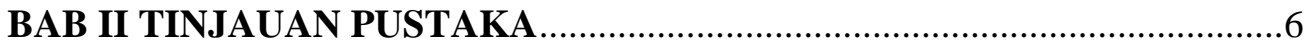

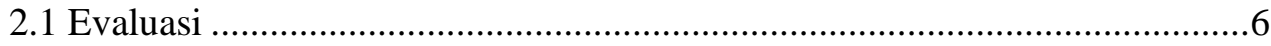

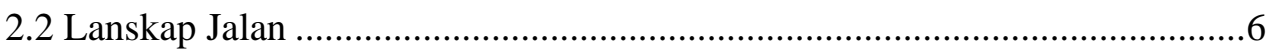

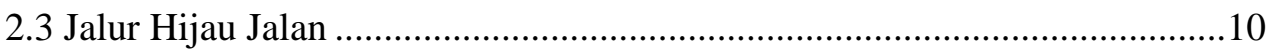

2.4 Fungsi Ekologis Tanaman dalam Lanskap...............................................11

2.5 Tanaman Sebagai Penyerap Gas Pencemar...................................................12

2.6 Tanaman Sebagai Penjerap Partikel ...........................................................14

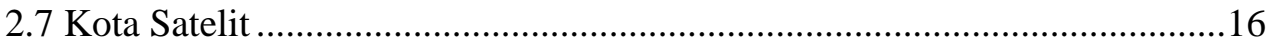

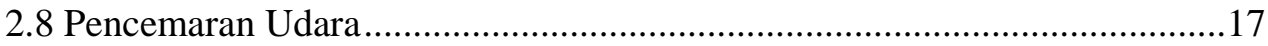

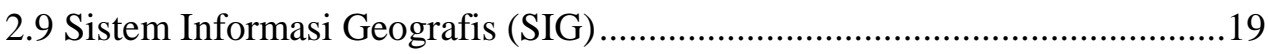

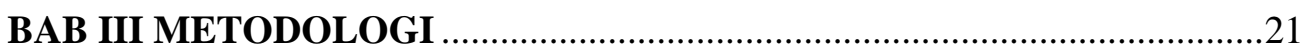

3.1 Waktu dan Tempat Penelitian ................................................................2

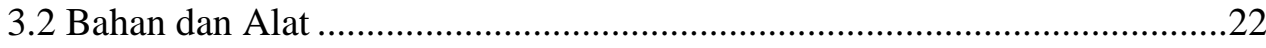

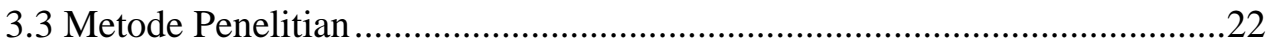

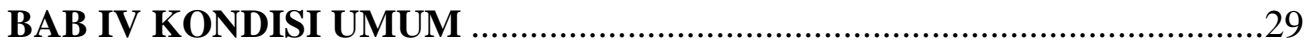

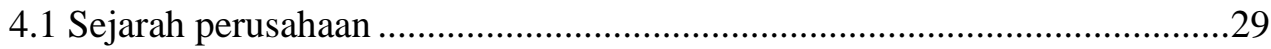

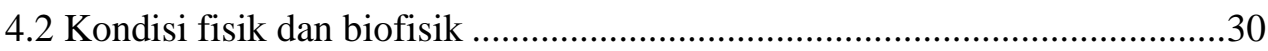

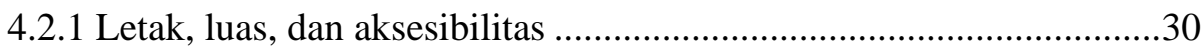

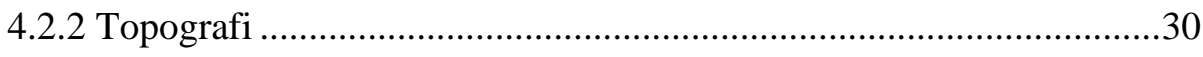

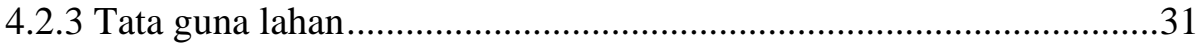

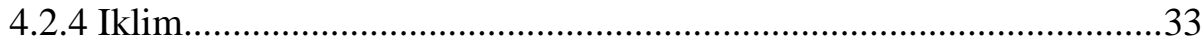

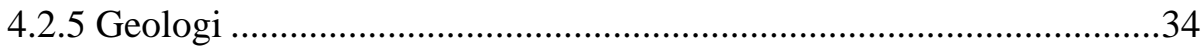




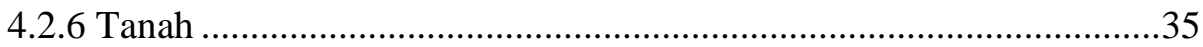

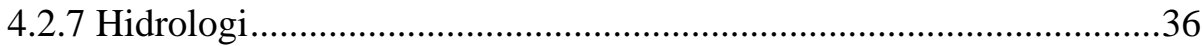

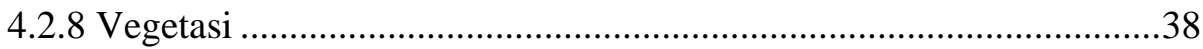

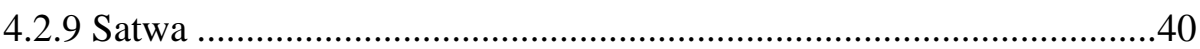

4.3 Kondisi Sosial Ekonomi .............................................................................41

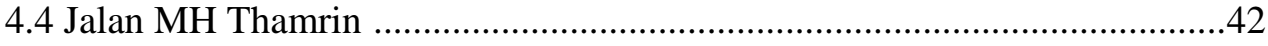

4.4.1 Lokasi dan dimensi ............................................................................42

4.4.2 Elemen pembentuk tapak.....................................................................43

4.4.3 Tata hijau jalan ..................................................................................4

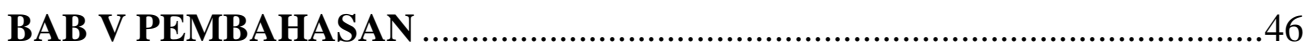

5.1 Lanskap Jalan MH Thamrin .........................................................................46

5.2 Identifikasi Karakteristik jalur hijau jalan ......................................................49

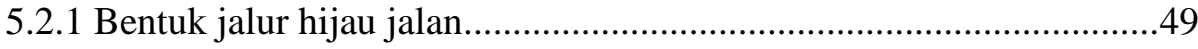

5.2.2 Identifikasi jenis vegetasi jalur hijau jalan ..........................................55

5.3 Analisis Fungsi Ekologis Jalur Hijau Jalan .....................................................63

5.3.1 Penyerap polutan gas .........................................................................64

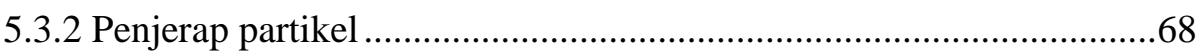

5.4 Penilaian Fungsi Ekologis Jalur Hijau Jalan .................................................71

5.4.1 Evaluasi Fungsi Ekologis Penyerap Polutan Gas ................................71

5.4.2 Evaluasi Fungsi Ekologis Penjerap Partikel ........................................77

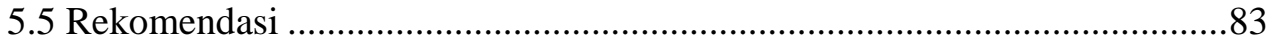

5.5.1 Jalur Hijau Jalan Untuk Menyerap Polutan Gas...................................84

5.5.2 Jalur Hijau Jalan Untuk Menjerap Partikel............................................86

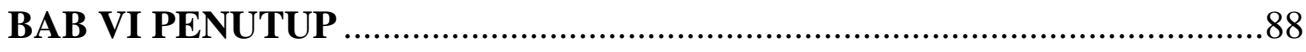

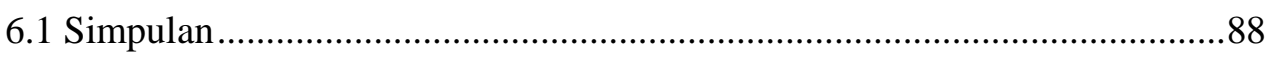

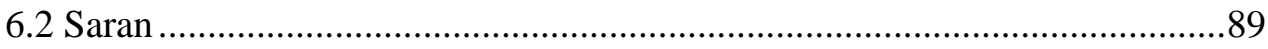

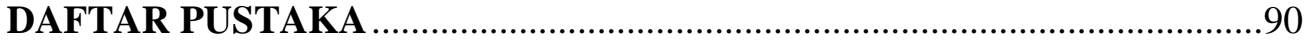

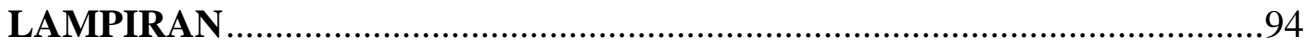




\section{DAFTAR TABEL}

No.

Teks

halaman

1. Toksisitas relatif polutan udara (Babcock dalam Fardiaz, 1992).......................18

2. Sumber dan persentase emisi polutan mayor (Simonds, 1978) .........................19

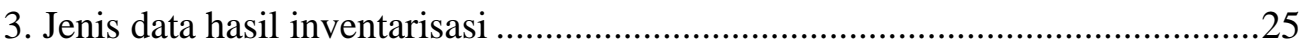

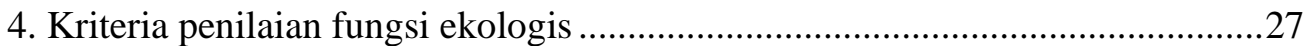

5. Peruntukkan kawasan perumahan Sentul City ...............................................32

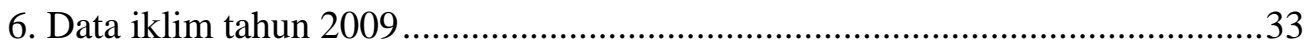

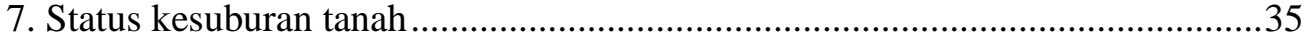

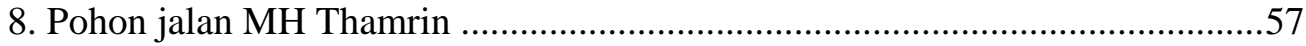

9. Tingkat toleransi pohon jalan MH Thamrin .....................................................60

10. Tingkat serapan ${ }^{15} \mathrm{~N}$ beberapa pohon jalan $\mathrm{MH}$ Thamrin ..............................61

11. Tingkat serapan karbon dioksida $\left(\mathrm{CO}_{2}\right)$ pohon jalan $\mathrm{MH}$ Thamrin .................62

12. Jumlah zat pencemar pada tahun 2009........................................................65

13. Tingkat pencemaran partikel tahun 2009 .....................................................69

14. Evaluasi fungsi reduksi polusi ……….......................................................

15. Hasil evaluasi kesesuaian pohon untuk fungsi reduksi polusi .........................76

16. Evaluasi fungsi penjerap partikel ..................................................................79

17. Hasil evaluasi kesesuaian untuk fungsi penjerap partikel...............................83 


\section{DAFTAR GAMBAR}

No.

Teks

halaman

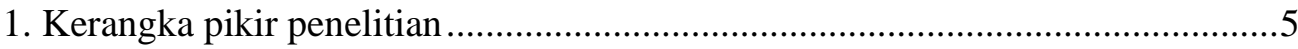

2. Tata letak jalur hijau jalan (Direktorat Jenderal Bina Marga, 1996) ..........................11

3. Tanaman menjernihkan udara (Carpenter et al., 1975).....................................12

4. Penjerapan partikel oleh pohon (Grey and Deneke, 1978) ...............................14

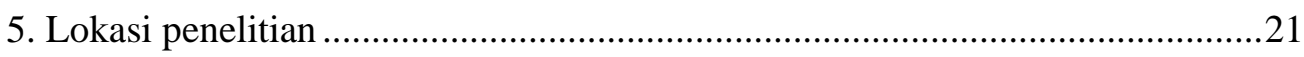

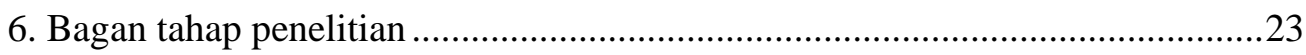

7. Bentukan bangunan di atas jalan.....................................................................

8. Topografi pada jalan MH Thamrin ...................................................................31

9. Kondisi tanah pada jalan MH Thamrin .............................................................31

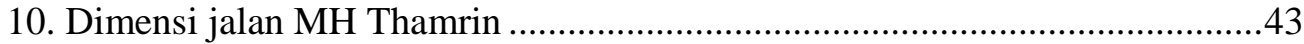

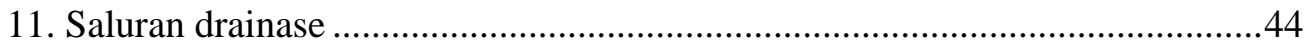

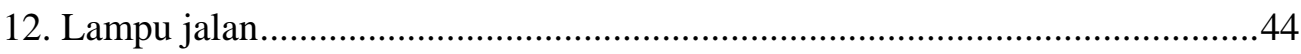

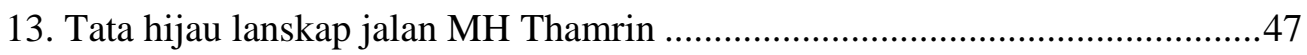

14. Tampak potongan jalan MH Thamrin............................................................46

15. Ruang terbuka hijau pada jalan utama .........................................................49

16. Penanaman pohon dengan perdu dan semak..................................................51

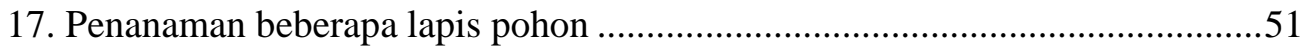

18. Tepi jalan pada bagian yang miring ..............................................................52

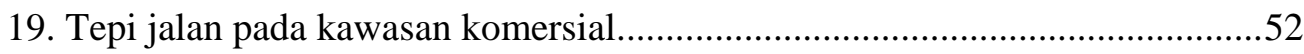

20. Penanaman pada tepi jalan yang miring.......................................................52

21. Penggunaan elemen keras pada median.........................................................53

22. Penanaman pohon dan semak pada median .....................................................53

23. Traffic islands dan rotunda pada jalan $\mathrm{MH}$ Thamrin .....................................54

24. Identifikasi jenis vegetasi jalur hijau jalan MH Thamrin ...............................58

25. Karakteristik daun untuk menjerap partikel ...............................................70

26. Evaluasi fungsi ekologis jalur hijau jalan untuk menyerap polutan gas ..........74

27. Potongan tampak jalur hijau jalan sebagai penyerap polutan gas....................75

28. Evaluasi fungsi ekologis jalur hijau jalan untuk menjerap partikel .................80

29. Potongan tampak jalur hijau jalan untuk menjerap partikel ...........................81

30. Jalur hijau jalan untuk menyerap polusi udara (PP No. 05 tahun 2008)..........85 


\section{DAFTAR LAMPIRAN}

No.

Teks

halaman

1. Jenis, letak, jumlah pohon pada jalur hijau jalan MH Thamrin .........................95

2. Elemen tanaman pada jalur hijau jalan MH Thamrin ........................................96

3. Data AMDAL kualitas udara Sentul City tahun 2009 .......................................98

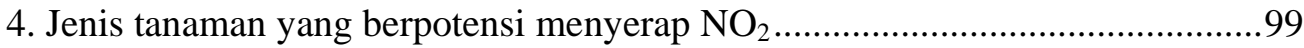

5. Daya serap pohon terhadap karbondioksida ...............................................102 


\section{BAB I \\ PENDAHULUAN}

\subsection{Latar Belakang}

Simonds (1983) menyebutkan bahwa kota merupakan pusat aktivitas ekonomi, sosial, dan politik yang besar dan populasi yang padat. Berdasarkan Undang-undang nomor 26 tahun 2007, kawasan perkotaan adalah wilayah yang mempunyai kegiatan utama bukan pertanian dengan susunan fungsi kawasan sebagai tempat permukiman perkotaan, pemusatan dan distribusi pelayanan jasa pemerintahan, pelayanan sosial, dan kegiatan ekonomi. Perkembangan pada kota terutama terjadi karena pertambahan jumlah penduduk di kota. Peningkatan jumlah penduduk menyebabkan meningkatnya kebutuhan lahan untuk tempat tinggal sekaligus berkurangnya lahan untuk jenis penggunaan lahan selain perumahan antara lain untuk pengembangan ruang terbuka hijau (Fandeli, 2009).

Terbatasnya lahan pada kawasan perkotaan mendukung perkembangan kawasan-kawasan di daerah sekitar kota. Kawasan yang berkembang tersebut disebut juga kota satelit, yaitu kota kecil di tepi sebuah kota besar dan sebagian besar penduduknya tergantung pada kehidupan di kota besar. Salah satu contoh kawasan kota satelit pada wilayah kabupaten Bogor yaitu Sentul City.

Seperti perkotaan pada umumnya, kota satelit dilengkapi berbagai elemen dan fasilitas kota. Jalan sebagai jalur sirkulasi merupakan elemen penting yang menghubungkan berbagai elemen dan fasilitas tersebut. Jalan merupakan akses untuk masuk ke suatu lahan dan bangunan, penghubung antar tata guna lahan yang ada, dan jalur pergerakan untuk orang dan barang (Harris dan Dines, 1988). Jalan-jalan pada perkotaan terutama memiliki lalu lintas yang padat akibat tingginya penggunaan kendaraan bermotor. Pembakaran bahan bakar pada kendaraan, merupakan salah satu penyebab pencemar udara karena menghasilkan zat pencemar udara antara lain karbon monoksida, karbon dioksida, nitrogen dioksida, dan sulfur dioksida (Wardhana, 2001). Pencemaran udara dapat menyebabkan kenyamanan pada lingkungan kota berkurang.

Dampak polusi udara dapat diimbangi dengan peningkatan kualitas dan kuantitas ruang terbuka hijau (RTH). Menurut Undang-undang nomor 26 tahun 
2007, ruang terbuka hijau merupakan area memanjang/jalur dan atau mengelompok, yang penggunaannya lebih bersifat terbuka, tempat tumbuh tanaman, baik tanaman yang tumbuh secara alamiah maupun sengaja ditanam. Keberadaan RTH diperlukan untuk menjaga keseimbangan lingkungan alam dan lingkungan binaan pada kawasan perkotaan. Fungsi RTH yang utama yaitu fungsi ekologis sebagai paru-paru kota, pengatur iklim mikro, peneduh, penyedia oksigen, penyerap air hujan, habitat satwa, penyerap polutan dan penahan angin. Selain itu, RTH juga memiliki fungsi sosial budaya, fungsi ekonomi dan fungsi estetis. RTH memperindah lingkungan kota dan memberi menciptakan keseimbangan dan keserasian suasana antara area terbangun dan non terbangun.

Kawasan permukiman Sentul City saat ini berada pada tahapan kegiatan operasional, sebagian kawasan baru masuk tahap konstruksi dan sebagian lagi masih dalam tahap pra konstruksi. Pada kondisi saat ini yaitu dengan kawasan yang sudah terbangun kurang lebih 40\%, pergerakan kendaraan masih tergolong rendah. Walaupun demikian, terdapat potensi peningkatan jumlah kendaraan seiring dengan perkembangan kawasan. Kawasan yang semakin berkembang mendukung peningkatan populasi penghuni dalam kawasan. Seiring dengan peningkatan populasi tersebut, terjadi juga peningkatan jumlah kendaraan. Hal ini menjadi salah satu penyebab peningkatan pencemaran udara, terutama pada jalan.

Bentuk penyediaan RTH pada jalan jalur hijau jalan merupakan. Jalur hijau jalan dapat berperan untuk mengurangi polusi akibat emisi dari kendaraan, yang antara lain berbentuk gas pencemar dan partikel padat. Seperti disebutkan oleh Grey dan Deneke (1978), tanaman dapat mengurangi konsentrasi polutan di udara melalui pelepasan oksigen dan pencampuran antara udara tercemar dengan udara bersih. Tanaman dapat mengurangi polusi udara melalui penyerapan gas pencemar dan penjerapan partikel. Karena itu, perkembangan jalan juga perlu memperhatikan pengembangan jalur hijau jalan.

Taman pada jalan utama kawasan, yaitu jalan MH Thamrin dan jalan Siliwangi, mendapatkan rekor MURI sebagai taman terluas pada jalan utama. Jalur hijau jalan utama ini dinilai sudah cukup estetis dilihat dari pemilihan vegetasi dan desain penanaman. Jalur hijau jalan selain untuk memenuhi aspek 
estetika pada jalan juga untuk memenuhi fungsi ekologis untuk mendukung lingkungan sekitarnya.

Jalur hijau jalan utama sudah estetis namun apakah jalur hijau jalan tersebut memiliki fungsi ekologis perlu diketahui lebih lanjut. Karena itu, dilakukan evaluasi terhadap fungsi ekologis jalur hijau jalan. Evaluasi dilakukan untuk mengetahui fungsi ekologis jalur hijau jalan dalam mengurangi pencemaran udara yaitu melalui menyerap polutan gas dan menjerap partikel. Evaluasi diharapkan dapat memberi masukan dan rekomendasi untuk pengembangan tapak selanjutnya.

\section{I.2 Tujuan}

Tujuan dari penelitian ini adalah:

1. Mengidentifikasi karakteristik jalur hijau jalan utama kawasan Sentul City.

2. Menganalisis dan mengevaluasi fungsi ekologis jalur hijau jalan dalam mengurangi polusi udara, yaitu fungsi ekologis menyerap polutan gas dan menjerap partikel, pada jalan utama kawasan Sentul City

3. Memberikan rekomendasi untuk mengoptimalkan fungsi ekologis jalur hijau jalan dalam mengurangi polusi udara, yaitu dengan menyerap polutan gas dan menjerap partikel.

\subsection{Manfaat}

Manfaat dari pelaksanaan studi ini adalah untuk :

1. Mengetahui fungsi ekologis jalur hijau jalan dalam mendukung lingkungan sekitarnya terutama dalam mengurangi polusi udara, dengan menyerap polutan gas dan menjerap partikel.

2. Sebagai rekomendasi dalam pengembangan jalur hijau jalan yang fungsional dan estetis bagi pengelola Sentul City.

\subsection{Kerangka pikir}

Peningkatan populasi pada kawasan perkotaan mendukung pengembangan kota-kota satelit di sekitar kota besar. Salah satu kota satelit yang berada di sekitar 
kawasan Jabodetabek yaitu Sentul City. Kawasan Sentul City merupakan kawasan hunian dan dilengkapi berbagai fasilitas pendukung. Salah satu elemen penting pada kawasan Sentul City adalah jalan yang menghubungkan berbagai area di dalam kawasan tersebut. Penelitian dilakukan pada jalan utama kawasan Sentul City yaitu jalan MH Thamrin. Jalan MH Thamrin dilengkapi ruang terbuka hijau yang estetis dan telah mendapatkan rekor MURI untuk luasnya. Ruang terbuka hijau pada jalan MH Thamrin berupa jalur hijau jalan. Jalur hijau jalan selain untuk menambah estetika tapak juga memiliki beragam fungsi ekologis. Kendaraan bermotor pada jalan dapat menjadi sumber pencemaran udara kawasan karena pembakaran bahan bakar pada kendaraan menghasilkan pencemar berupa gas dan partikel. Penelitian ini difokuskan pada fungsi ekologis jalur hijau jalan untuk mengurangi polusi udara, melalui menyerap polutan gas dan menjerap partikel. Inventarisasi dilakukan untuk mendapatkan data lapang terkait dengan fungsi yang diteliti. Kondisi lapang dianalisis sesuai dengan standar yang didapat dari berbagai literatur. Selain itu dilakukan juga analisis secara spasial dengan bantuan GIS (Geographic Information Systems). Evaluasi yang dilakukan akan menghasilkan suatu rekomendasi yang diberikan kepada pihak pengelola Sentul City. 


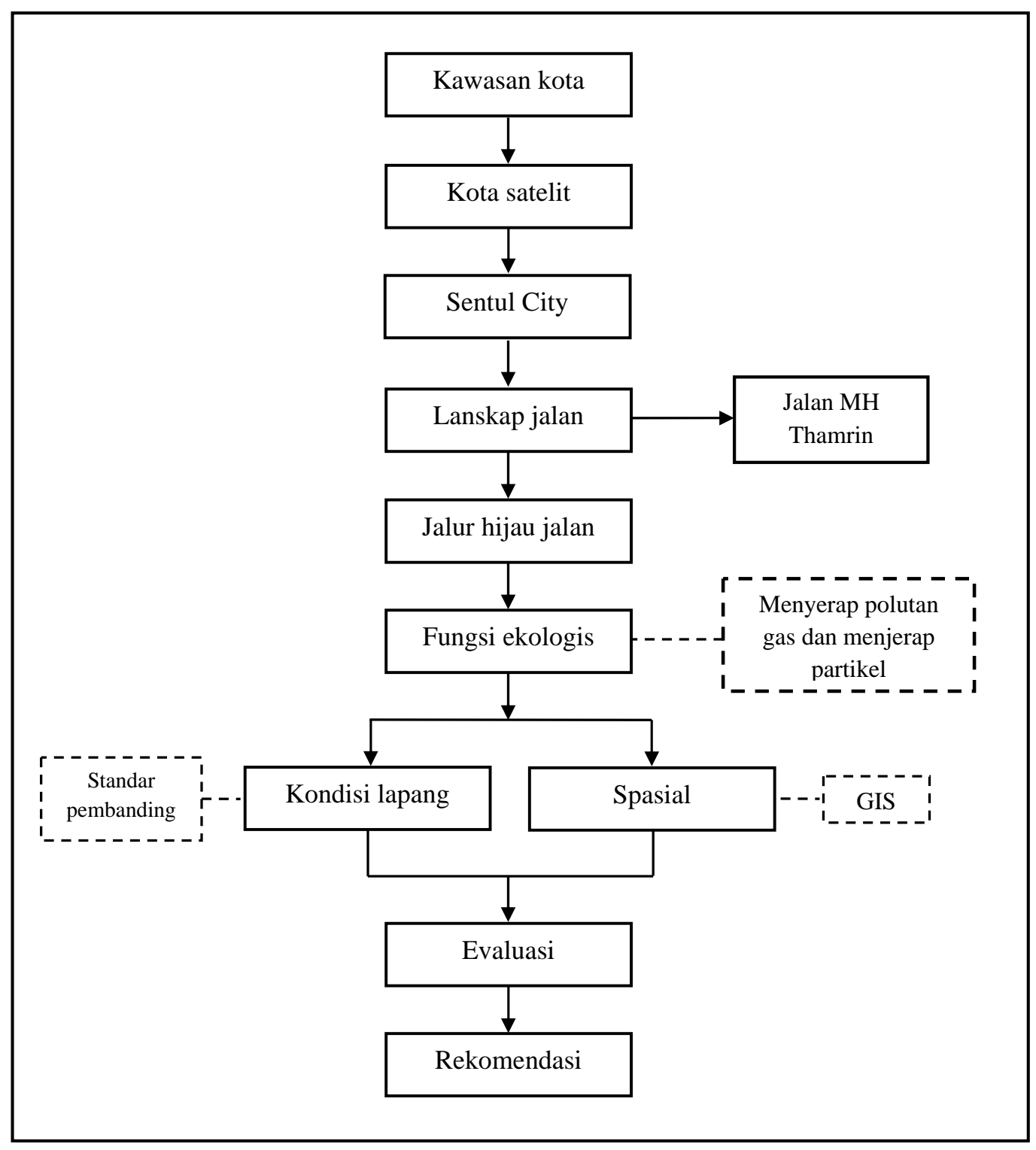

Gambar 1 Kerangka pemikiran 


\section{BAB II \\ TINJAUAN PUSTAKA}

\subsection{Evaluasi}

Evaluasi adalah kegiatan menilai, menaksir, dan mengkaji (Echols dan Shadily 1996). Menurut Eliza dalam Vitasari (2004), evaluasi adalah suatu tindakan yang digunakan atau dilakukan untuk menelaah atau menduga hal-hal yang sudah diputuskan untuk mengetahui kelemahan dan kelebihan keputusan tersebut untuk selanjutnya ditentukan langkah-langkah alternatif perbaikannya bagi kelemahan tersebut. Evaluasi perlu dilakukan untuk mengetahui apakah tujuan telah tercapai dan peningkatan yang perlu dilakukan.

Kegiatan evaluasi bertujuan menyeleksi dan menampilkan informasi yang diperlukan dalam mendukung pengambilan kesimpulan dan keputusan tentang suatu nilai serta nilainya (Anonim dalam Vitasari, 2004). Anonim dalam Vitasari 2004 juga menyatakan bahwa evaluasi dilakukan untuk menentukan keputusan apa akan melanjutkan suatu program yang dinilai sukses atau menghentikannya. Evaluasi dilakukan dengan menggunakan pembanding yaitu perbandingan hasil perencanaan dengan tujuan yang ditetapkan oleh desainer. Hasil evaluasi digunakan untuk membantu memutuskan apa suatu program akan dilanjutkan atau dihentikan dan bagaimana cara pengembangannya.

\subsection{Lanskap Jalan}

Menurut Undang-Undang Republik Indonesia Nomor 38 tahun 2004, jalan adalah suatu prasarana perhubungan darat yang meliputi segala bagian jalan, termasuk bangunan pelengkap dan perlengkapannya yang diperuntukkan bagi lalu lintas, yang berada pada permukaan tanah, di atas permukaan tanah, di bawah permukaan tanah, dan/atau air serta di atas permukaan air, kecuali jalan kereta api, jalan lori, dan jalan kabel. Harris dan Dines (1988) menjelaskan bahwa adanya jalan atau sirkulasi kendaraan di jalan raya mengakomodasikan tiga tujuan utama yaitu menyediakan akses untuk masuk ke suatu lahan dan bangunan, menghubungkan antar tata guna lahan yang ada, dan menyediakan jalur pergerakan untuk orang dan barang. 
Secara umum, Harris dan Dines mengelompokkan sistem jalan menjadi freeway (jalan tol), jalan arteri, jalan kolektor, dan jalan lokal. Sementara itu, Chiara dan Koppelman membagi jalan menjadi 5 tipe yaitu jalan utama (arteri utama), jalan sekunder (arteri kecil), jalan kolektor, jalan lokal, cul-de-sac.

Berdasarkan peruntukannya, jalan dibedakan menjadi jalan umum dan jalan khusus (UU No. 38 tahun 2004). Jalan umum adalah jalan yang diperuntukkan bagi lalu lintas umum dan dikelompokkan menurut sistem, fungsi, status, dan kelas. Jalan khusus adalah jalan yang dibangun oleh instansi, badan usaha, perseorangan, atau kelompok masyarakat untuk kepentingan sendiri, diperuntukkan bukan bagi lalu lintas umum dalam rangka distribusi barang dan jasa yang diperlukan. Jalan khusus tidak diperuntukkan bagi lalu lintas umum. Termasuk ke dalamnya antara lain jalan inspeksi pengairan, jalan inspeksi saluran minyak atau gas, jalan perkebunan, jalan pertambangan, jalan kehutanan, jalan komplek bukan untuk umum dan jalan untuk keperluan pertahanan dan kemanan Negara.

Jalan umum dikelompokkan lebih lanjut menurut fungsi, status dan kelasnya. Jalan umum menurut statusnya dikelompokkan ke dalam jalan nasional, jalan provinsi, jalan kabupaten, jalan kota, dan jalan desa. Menurut fungsinya, jalan umum dikelompokkan menjadi jalan arteri, jalan kolektor, jalan lokal, dan jalan lingkungan.

a. Jalan arteri merupakan jalan umum yang berfungsi melayani angkutan utama dengan ciri perjalanan jarak jauh, kecepatan rata rata tinggi, dan jumlah jalan masuk dibatasi secara berdaya guna.

b. Jalan kolektor merupakan jalan umum yang berfungsi melayani angkutan pengumpul atau pembagi dengan ciri perjalanan jarak sedang, kecepatan rata-rata sedang, dan jumlah jalan masuk dibatasi.

c. Jalan lokal merupakan jalan umum yang berfungsi melayani angkutan setempat dengan ciri perjalanan jarak dekat, kecepatan rata-rata rendah, dan jumlah jalan masuk tidak dibatasi.

d. Jalan lingkungan merupakan jalan umum yang berfungsi melayani angkutan lingkungan dengan ciri perjalanan jarak dekat, dan kecepatan rata-rata rendah. 
Jalan umum juga dikelompokkan berdasarkan kelas jalan (UU RI No. 22 Tahun 2009). Pengelompokkan jalan menjadi beberapa kelas didasarkan pada fungsi dan intensitas lalu lintas serta daya dukung untuk menerima muatan sumbu terberat dan dimensi kendaraan bermotor. Berdasarkan kelas jalannya, jalan umum dikelompokkan menjadi jalan kelas I, jalan kelas II, jalan kelas III, dan jalan kelas khusus. Jalan kelas I, yaitu jalan arteri dan kolektor yang dapat dilalui kendaraan bermotor dengan ukuran lebar tidak melebihi 2500 mm, ukuran panjang tidak melebihi 18000 mm, ukuran paling tinggi 4200 mm, dan muatan sumbu terberat 10 ton. Jalan kelas II, yaitu jalan arteri, jalan kolektor, lokal, dan lingkungan yang dapat dilalui kendaraan bermotor dengan ukuran lebar tidak melebihi 2500 mm, ukuran panjang tidak melebihi 12000 mm, ukuran paling tinggi $4200 \mathrm{~mm}$, dan muatan sumbu terberat 8 ton. Jalan kelas III, yaitu jalan arteri, jalan kolektor, lokal, dan lingkungan yang dapat dilalui kendaraan bermotor dengan ukuran lebar tidak melebihi 2100 mm, ukuran panjang tidak melebihi 9000 mm, ukuran paling tinggi 3500 mm, dan muatan sumbu terberat 8 ton. Jalan kelas khusus, yaitu jalan arteri yang dapat dilalui kendaraan bermotor dengan ukuran lebar tidak melebihi 2500 mm, ukuran panjang tidak melebihi 18000 mm, ukuran paling tinggi 4200 mm, dan muatan sumbu terberat lebih dari 10 ton.

Jalan memiliki beberapa bagian jalan. Bagian-bagian jalan tersebut meliputi ruang manfaat jalan, ruang milik jalan, dan ruang pengawasan jalan (UU RI No 38 tahun 2004 ; UU RI No 13 tahun 1980).

a. Daerah manfaat jalan adalah suatu daerah yang dimanfaatkan untuk konstruksi jalan terdiri dari badan jalan, saluran tepi jalan, dan ambang pengamannya.

b. Daerah milik jalan meliputi daerah manfaat jalan dan sejalur tanah tertentu, di luar daerah manfaat jalan. Daerah milik jalan dibatasi tanda batas daerah milik jalan.

c. Daerah pengawasan jalan merupakan sejalur tanah tertentu di luar daerah milik jalan yang ada di bawah pengawasan Pembina jalan. Adanya daerah pengawasan jalan dimaksudkan agar tidak mengganggu pandangan pengemudi dan konstruksi jalan, dalam hal tidak cukup luasnya daerah milik jalan. 
Lanskap kehidupan manusia terdiri dari tempat dan jalan. Jalan-jalan kota merupakan jalur atau garis pusat kegiatan dimana jalan dan tempat berkombinasi serta terdapat kehidupan dan pergerakan yang intensif (Simonds, 1978). Lanskap jalan adalah wajah dari karakter lahan atau tapak yang terbentuk dari elemen lanskap alamiah seperti bentuk topografi lahan yang mempunyai panorama indah, maupun yang terbentuk dari elemen lanskap buatan manusia yang disesuaikan dengan kondisi lahannya (Direktorat Jenderal Bina Marga, 1996). Sementara itu, definisi streetscape menurut JAANUS (Japanese Architecture and Art Net Users System) dalam Roychansyah (2007) yaitu ruang linear yang dibatasi oleh jalan itu sendiri dan bagian muka gedung pada deretan bangunan, dinding dan lain-lain di sekitarnya.

Lanskap jalan mempunyai ciri khas karena harus disesuaikan dengan persyaratan geometrik jalan dan diperuntukkan terutama bagi pengguna jalan serta diusahakan untuk menciptakan lingkungan yang indah, nyaman, dan memenuhi fungsi keamanan (Direktorat Jenderal Bina Marga, 1996). Agar tercipta lingkungan jalan yang nyaman dan teduh, diperlukan tanaman peneduh pada jalan (Dahlan, 2004). Adanya tanaman pada jalan menurut Carpenter et al (1975) dapat memberi karakter dan melembutkan struktur jalan yang keras dan kaku.

Direktorat Jenderal Bina Marga (1996) menjelaskan bahwa persyaratan utama dalam memilih jenis tanaman lanskap jalan yaitu perakaran tidak merusak konstruksi jalan, mudah dalam perawatan, batang/percabangan tidak mudah patah, daun tidak mudah rontok/gugur. Selain itu, pemilihan tanaman jalan perlu mempertimbangkan faktor keamanan pemakai jalan. Carpenter et. al (1975) juga menjelaskan bahwa tanaman jalan harus toleran pada polusi udara, ruang pertumbuhan akar yang terbatas serta toleran pada kondisi panas, dingin, angin dan kondisi lainnya pada jalan. Tanaman pada lanskap jalan sebaiknya tidak mudah patah, tanaman tidak berantakan, tidak menyulitkan, tahan hama penyakit dan tidak memiliki berbahaya. Dahlan (2004) menambahkan bahwa tanaman jalan sebaiknya tidak mempunyai akar yang besar di permukaan tanah, tahan terhadap hembusan angin lemah sampai sedang, buah berukuran tidak terlalu besar, serasah sedikit, teduh tapi tidak terlalu gelap, dan tahan terhadap pencemar dari kendaraan 
bermotor serta memiliki ciri fisik yang menarik antara lain bentuk kanopi, warna daun serta bunga yang indah.

\subsection{Jalur Hijau Jalan}

Jalur hijau jalan merupakan salah satu bentuk penyediaan ruang terbuka hijau pada kota. Berdasarkan Undang-undang Republik Indonesia nomor 26 tahun 2007, RTH atau ruang terbuka hijau sendiri didefinisikan sebagai area memanjang, jalur, dan atau mengelompok, yang penggunaannya lebih bersifat terbuka, dan merupakan tempat tumbuh tanaman, baik yang tumbuh secara alami maupun sengaja ditanam. Proporsi luas ruang terbuka hijau pada kota paling sedikit 30\% luas wilayah kota. Proporsi ruang terbuka hijau $30 \%$ tersebut merupakan ukuran minimal untuk menjamin keseimbangan ekosistem kota, meningkatkan ketersediaan udara bersih bagi masyarakat dan juga meningkatkan nilai estetika kota (UU No. 26 tahun 2007).

Fungsi utama ruang terbuka hijau yaitu fungsi ekologis untuk menjamin sistem sirkulasi udara kota, pengatur iklim mikro, peneduh, produsen oksigen, penyerap air hujan, penyerap polutan, habitat satwa, dan penahan angin. Ruang terbuka hijau selain memiliki fungsi ekologis juga memiliki fungsi sosial budaya, fungsi ekonomi, dan fungsi estetika. RTH juga memiliki fungsi sosial budaya dan fungsi ekonomi. Ruang terbuka hijau juga berfungsi untuk memperindah lingkungan kota dan menciptakan keseimbangan dan keserasian suasana pada area yang terbangun dan tidak terbangun (Peraturan Menteri Pekerjaan Umum No. 05 Tahun 2008). Manfaat adanya RTH yaitu terbentuknya keindahan dan kenyamanan. Manfaat lain RTH antara lain pembersihan udara, menjamin ketersediaan air tanah, dan konservasi hayati. RTH juga memberi manfaat bagi kesehatan antara lain karena tanaman dalam RTH dapat menyerap karbondioksida serta zat pencemar udara lain dan menghasilkan oksigen (Direktorat Jendral Penataan Ruang, 2006).

Pembangunan fisik kota yang meningkat, pertumbuhan penduduk, dan berbagai aktivitas kota mengakibatkan berkurangnya ruang terbuka hijau kota (RTHK). Berkurangnya RTH kota akan berpengaruh langsung pada lanskap kawasan dan menurunnya kualitas lingkungan hidup dan dapat menyebabkan 
terjadinya perubahan ekosistem alami (Fandeli, 2009). Pada kawasan perkotaan ruang terbuka hijau pada kota disediakan dalam bentuk taman kota, hutan kota, sabuk hijau, jalur hijau jalan, RTH ruang pejalan kaki, RTH di bawah jalan layang, dan RTH fungsi tertentu seperti RTH sempadan kereta api dan RTH pemakaman.

Menurut Peraturan Menteri Pekerjaan Umum No. 05 Tahun 2008, ruang terbuka hijau untuk jalur hijau jalan dapat disediakan dengan penempatan tanaman antara 20-30\% dari ruang milik jalan sesuai dengan kelas jalan. Pemilihan jenis tanaman untuk jalur hijau jalan memperhatikan fungsi tanaman dan persyaratan penempatannya.

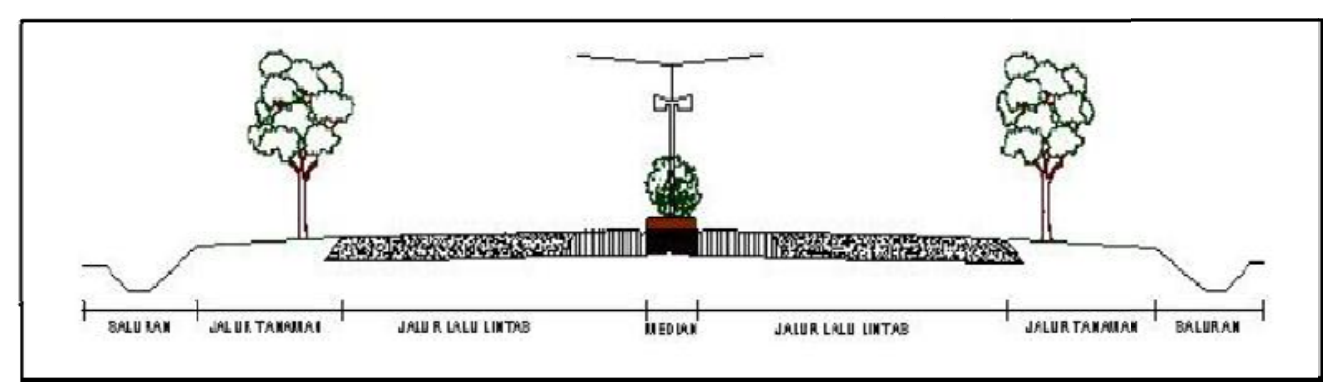

Gambar 2 Tata letak jalur hijau jalan (Direktorat Jenderal Bina Marga, 1996)

Pada jalur hijau jalan, tanaman disediakan pada tepi jalan serta median dan pulau jalan. Jalur tanaman tepi pada ruang terbuka hijau jalur hijau jalan memiliki fungsi antara lain peneduh, penyerap polusi udara, peredam kebisingan dan pemecah angin. Median pada jalur hijau jalan berfungsi sebagai penahan silau lampu kendaraan.

\subsection{Fungsi Ekologis Tanaman Dalam Lanskap}

Ekologi berasal dari bahasa Yunani yaitu oikos yang berarti rumah atau tempat untuk tinggal. Secara umum, ekologi didefinisikan sebagai studi tentang hubungan dari organisme atau kelompok organisme dengan lingkungannya atau ilmu tentang hubungan timbal balik antara mahluk hidup dan lingkungannya (Odum, 1959). Mahluk hidup, yaitu manusia, tumbuhan dan hewan, memiliki hubungan timbal balik dengan lingkungannya. 
Tanaman turut berperan dalam menjaga keseimbangan ekologis pada lingkungan. Irwan (2008) menjelaskan bahwa vegetasi dalam ekosistem berperan sebagai produsen utama yang mengubah energi surya menjadi energi potensial. Energi yang dihasilkan oleh vegetasi merupakan sumber hara mineral dan perubah terbesar lingkungan yang dapat meningkatkan kualitas lingkungan. Benson dan Roe (2000) menyebutkan bahwa vegetasi penting dalam berfungsi secara ekologis dan merupakan salah satu faktor penting dalam menciptakan keberlanjutan lingkungan. Beberapa fungsi ekologis tanaman dan vegetasi antara lain kontrol polusi, meningkatkan kualitas udara, ameliorasi iklim, mereduksi bising, menyimpan karbon, dan sebagai keragaman hayati.

Branch (1995) menjelaskan bahwa unsur vegetasi dapat meningkatkan daya tarik kota dan membantu menjaga kebersihan udara. Lebih lanjut Carpenter (1975) menjelaskan bahwa tanaman memiliki efek penting pada suhu udara udara. Selain itu, vegetasi dapat juga mengurangi terjadinya erosi tanah dan bahaya tanah longsor. Carpenter et.al (1975) menambahkan bahwa kehadiran tanaman di lingkungan perkotaan memberikan suasana alami.

\subsection{Tanaman Sebagai Penyerap Gas Pencemar}

Tanaman dapat mengurangi polutan udara melalui proses oksigenasi, yaitu proses pelepasan oksigen ke atmosfer, dan dilusi, yaitu pencampuran udara tercemar dengan udara bersih. Ketika udara yang tercemar mengalir di dalam dan sekitar tanaman dan melewati udara bersih dan beroksigen, terjadi pencampuran antara udara yang tercemar dengan udara bersih sehingga konsentrasi zat pencemar udara berkurang (Grey dan Deneke, 1978).

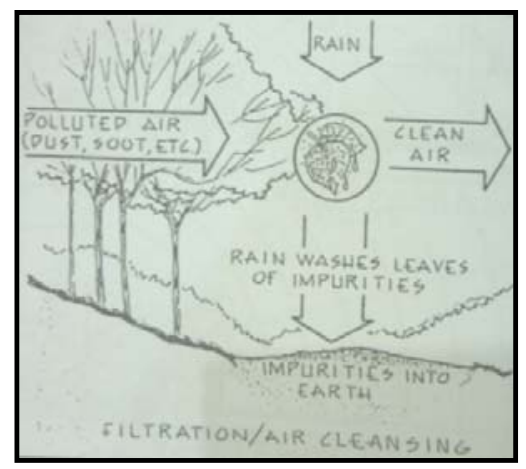

Gambar 3 Tanaman menjernihkan udara (Carpenter et al., 1975) 
Berdasarkan penelitian terdahulu, didapatkan perhitungan bahwa sejenis pohon douglas-fir (salah satu jenis cemara) dengan diameter batang 15 inchi berpotensi membersihkan 43,5 pound $\mathrm{SO}_{2}$ per tahun dengan konsentrasi $\mathrm{SO}_{2}$ pada atmosfer 0,25 ppm. Dengan demikian, satu acre lahan tanaman ini dapat membersihkan 3,7 ton $\mathrm{SO}_{2}$ pertahun (Carpenter, 1975). Penelitian lain menunjukkan bahwa area hijau seluas 500 meter di sekitar pabrik dapat menurunkan konsentrasi sulfur dioksida $\left(\mathrm{SO}_{2}\right)$ sebanyak 67\% (Robinette 1972 dalam Grey dan Deneke 1978). Penelitian tentang pencemaran ozon dan area hutan menunjukkan bahwa massa udara dengan konsentrasi ozon sebesar 150 ppm yang dilepaskan di hutan selama 8 jam, akan diserap oleh vegetasi sebesar 80\% di antaranya (Grey dan Deneke, 1978). Hasil-hasil tersebut membuktikan bahwa tanaman efektif dalam membersihkan polutan dari udara.

Tanaman menyerap karbondioksida dan melepaskan oksigen. Tanaman memiliki efek yang kecil pada tingkat karbon dioksida dan oksigen kota. Walaupun demikian, sedikit penurunan pada tingkat suplai oksigen dunia akan menghasilkan peningkatan yang cukup besar pada persentase karbon dioksida (Harris et al 1999). Schmid dalam Harris et al (1999) menemukan bahwa konsentrasi ozon berkurang dengan cepat pada siang hari dimana tanaman bertranspirasi dengan cepat dibandingkan pada malam hari. Transpirasi mendinginkan udara yang akan memperlambat pembentukan ozon. Nitrogen dioksida dihilangkan secara parsial oleh presipitasi.

Polutan diserap oleh jaringan tanaman yang aktif, terutama di daun dan dijerap pada permukaan tanaman (Harris et al 1999). Tanaman dapat menjadi penyaring yang efektif dan dapat digunakan untuk pada area-area strategis untuk membersihkan udara. Tanaman dapat menyerap dan menjerap gas dan polutan padat sampai pada batas tertentu yang dapat ditoleransi oleh tanaman.

Penggunaan tanaman yang peka terhadap polusi udara pada lingkungan yang tercemar berat dapat menyebabkan tumbuhan menderita bahkan mati. Dengan diketahuinya jenis tanaman yang tahan terhadap pencemar udara, tanaman akan dapat tumbuh dengan baik walaupun terkena paparan pencemar udara sedang sampai tinggi (Dahlan, 2004). Karena itu, pemilihan tanaman untuk 
daerah dengan tingkat pencemaran tinggi, misalnya jalan yang tercemar, perlu dilakukan dengan cermat.

Fakuara (1986) dalam Setiawati (2000) menjelaskan bahwa jenis tanaman yang dapat menyerap gas antara lain tanaman yang mempunyai banyak stomata, tahan terhadap gas tertentu dan tingkat pertumbuhan tanaman cepat. Kemampuan daun tanaman dalam menyerap gas beracun pencemar udara dipengaruhi beberapa faktor antara lain daya kelarutan polutan di dalam air/cairan sel, kelembaban lingkungan di sekitar daun, intensitas cahaya matahari, kedudukan daun, keadaaan saat penyerapan (gelap/terang) (Smith, 1981 dalam Dahlan, 2004).

Selain vegetasi, pergerakan angin juga dapat mempengaruhi penyebaran polusi udara. Karena itu, untuk mengurangi polusi udara, penanaman vegetasi dapat dilakukan tegak lurus dengan arah angin (Grey dan Deneke, 1978). Selain itu, penanaman juga ditempatkan di sekitar sumber polusi. Penanaman yang terbuka sebaiknya juga dikombinasikan dengan barrier yang padat.

\subsection{Tanaman Sebagai Penjerap Partikel}

Partikel pencemar udara disebabkan oleh pembakaran bahan bakar fosil, proses-proses industri, erosi tanah, dan reaksi kompleks antara matahari dan polutan gas. Partikel pencemar tersebut walaupun disaring sebelum memasuki tubuh manusia, dapat menyebabkan gangguan pernapasan, serangan jantung dan kanker (Harris, Clark, and Matheny, 1999). Pengurangan partikel dari udara sebagian besar dilakukan oleh angin. Angin membawa partikel-partikel tersebut. Selain angin, reduksi partikel dari udara juga disebabkan oleh tanaman. Partikel dan debu dijerap oleh tanaman terutama pada daun dan permukaan tanaman.

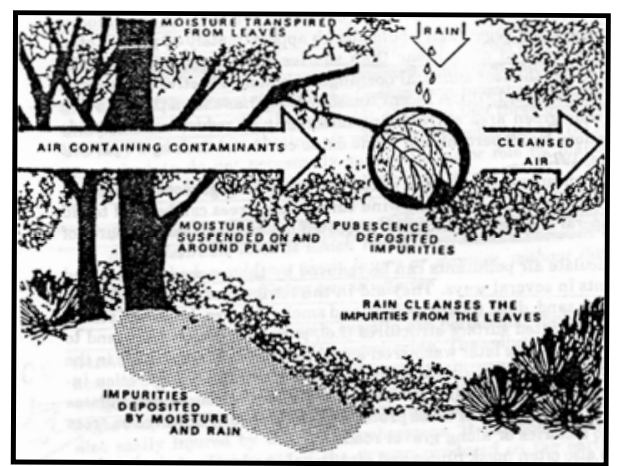

Gambar 4 Penjerapan partikel oleh pohon (Grey and Deneke, 1978) 
Tanaman juga dapat mereduksi kandungan logam di udara seperti timah, nikel, kadmium, dan krom. Penelitian Bertnatzky mengenai jalan di Frankurtz menyatakan bahwa pada jalan yang ditanami pohon terdapat sekitar 3000 partikel per liter (quart) udara sementara jalan tanpa pohon memiliki 10000-12000 partikel per liter udara (Harris et al, 1999). Carpenter (1975) juga menjelaskan bahwa udara yang berdebu berkurang sebanyak 75 \% dengan penanaman tanaman seluas 200 yard.

Menurut Carpenter (1975), permukaan daun yang berambut pada beberapa tanaman memerangkap debu dan jelaga dengan cukup efektif dibuktikan dengan kotornya daun pada beberapa vegetasi. Dahlan (1989) juga menjelaskan bahwa berdasarkan penelitian-penelitian sebelumnya diketahui bahwa tanaman dengan daun kasar atau berbulu mengendapkan timbal lebih tinggi dibandingkan dengan tumbuhan berdaun licin. Vegetasi yang selalu berdaun hijau (evergreens) direkomendasikan untuk menjerap partikel dan debu karena sifatnya yang berdaun sepanjang daun (Harris, Clark, and Matheny, 1999). Taihuttu (2001) melakukan penelitian terhadap tingkat jerapan partikulat pada beberapa jenis tanaman dan menyimpulkan bahwa tanaman berdaun jarum, serta tanaman yang berdaun besar, kasar, dan berbulu memiliki tingkat jerapan partikulat yang tinggi.

Selain penjerapan pada daun, penjerapan terhadap partikel juga dilakukan di berbagai bagian tumbuhan seperti ranting dan batang. Dahlan (1989) menjelaskan bahwa ranting pohon yang berbulu menjerap partikel timbal dan seng lebih banyak dibandingkan ranting yang berkulit licin. Pohon berkulit kasar dapat menyerap timbal lebih tinggi dibandingkan dengan pohon berkulit licin. Kemampuan pembersihan pencemaran partikel juga dipengaruhi oleh kepadatan dan struktur vegetasi. Vegetasi multilayer, yaitu terdiri dari beberapa lapis tanaman meliputi penutup tanah, semak, dan pohon, lebih efektif dalam menjerap partikel. Vegetasi yang padat dapat membersihkan partikel dengan baik.

Jenis tanaman yang memiliki ketahanan tinggi terhadap pencemaran debu semen dan mampu menyerap dan menjerap debu semen antara lain mahoni (Swietenia macrophylla), bisbul (Diospyros discolor), tanjung (Mimusoph elengi), kenari (Canarium commune), meranti merah (Shorea leprosula), kerai payung (Filicium decipiens), dan kayu hitam (Diospyros celebica). Sementara itu, duwet 
(Eugenia cuminii), medang lilin (Litsea roxburghii), dan sempur (Dilenia ovata) peka terhadap debu semen dan kemampuan menjerap dan menyerap partikel debu rendah (Dahlan, 2004).

\subsection{Kota Satelit}

Kawasan perkotaan menurut Undang-undang nomor 26 tahun 2007 merupakan wilayah dengan kegiatan utama bukan pertanian dengan susunan fungsi kawasan sebagai tempat permukiman perkotaan, pemusatan dan distribusi pelayanan jasa pemerintahan, pelayanan sosial, dan kegiatan ekonomi. Kota merupakan tempat dimana manusia hidup, berinteraksi antara satu sama lain dan mahluk hidup lainnya dan juga elemen abiotik. Kota dapat dikatakan sebagai ekosistem seperti yang lainnya karena kota terbentuk dari interaksi antara komponen hidup dan tak hidup (Newman dan Jennings, 2008). Sebuah kota mempunyai fungsi majemuk antara lain sebagai pusat populasi, perdagangan, pemerintahan, industri maupun pusat budaya dari suatu wilayah. Berjalannya fungsi-fungsi kota tersebut perlu ditunjang dengan sarana dan prasarana yang memadai seperti adanya kawasan pemukiman, perdagangan, pemerintah, industri, sarana kebudayaan, kesehatan, rekreasi, dan lainnya (Irwan, 2008). Lahan perkotaan yang terbatas serta harga lahan yang tinggi di kawasan perkotaan menyebabkan munculnya kawasan perumahan di daerah pinggiran kota (hinterland), dengan menggunakan konsep kota baru (Handayani, 2000).

Kota satelit (satellite town atau satellite city) adalah suatu konsep pada urban planning yang merujuk kepada suatu area metropolitan yang lebih kecil, berlokasi dekat, serta sebagian besar tidak bergantung pada kota metropolitan yang lebih besar (Anonim, 2011). Kota satelit berada di dekat kota metropolitan yang besar. Umumnya kota satelit merupakan kota berukuran kecil atau sedang. Penghuni kota satelit pada umumnya merupakan komuter dari kota besar tersebut (Anonim, 2009). Kota satelit merupakan daerah penunjang bagi kota-kota besar di sekitarnya dan juga merupakan akses untuk menuju ke kota besar. Karena kota satelit juga berfungsi sebagai penunjang kota besar, maka implikasi daripada kota satelit sebagai penunjang akan tampak pada hidup keseharian warganya (Anonim, 2009). 


\subsection{Pencemaran Udara}

Polusi atau pencemaran pada awalnya merupakan definisi yang diberikan terhadap hal-hal yang menyebabkan gangguan kesehatan umum. Sekarang ini penekanan polusi telah bergeser ke arah kualitas hidup. Pengertian polusi meluas mencakup semua bentuk degradasi lingkungan. Simonds (1978) menjelaskan bahwa polusi terjadi ketika suatu aktivitas atau proses menghasilkan produk samping yang mengganggu dan mengakibatkan terganggunya susunan atau sistem alami atau buatan.

Udara merupakan komponen penting dalam kehidupan manusia. Tanpa udara, tidak ditemukan adanya kehidupan. Manusia bernapas dengan udara. Tercemarnya udara akan menyulitkan pernapasan sehingga kualitas kehidupan menurun (Frick dan Suskiyanto, 2007). Komposisi udara mencakup 78\% nitrogen, $21 \%$ oksigen dan sisanya terdiri dari karbon dioksida dan unsur-unsur lain (Simonds, 1978). Fardiaz (1992) menjelaskan bahwa udara di alam tidak pernah ditemukan dalam keadaan bersih tanpa polutan sama sekali. Proses-proses alami seperti aktivitas vulkanik, pembusukan sampah tanaman, kebakaran hutan, dan sebagainya menghasilkan produk samping berupa gas-gas sulfur dioksida, hidrogen sulfida, dan karbon monoksida.

Pencemaran udara adalah adanya bahan-bahan atau zat-zat asing di dalam udara yang menyebabkan perubahan susunan (komposisi) udara dari dalam keadaan normalnya (Wardhana, 2001). Kehadiran bahan atau zat asing ini pada jumlah tertentu dan waktu yang cukup lama akan dapat mengganggu kehidupan manusia, hewan, dan binatang.

Grey dan Deneke (1978) menyebutkan bahwa polutan udara dapat berbentuk gas maupun partikel. Komponen pencemar udara yang banyak berpengaruh pada pencemaran udara yaitu karbon monoksida (CO), nitrogen oksida $\left(\mathrm{NO}_{\mathrm{x}}\right)$, belerang oksida $\left(\mathrm{SO}_{\mathrm{x}}\right)$, hidrokarbon $(\mathrm{HC})$, partikel (particulate). Jenis-jenis polutan ini termasuk dalam golongan pencemar udara primer yang jumlahnya mencakup 90\% dari jumlah total polutan udara. Kelima kelompok pencemar udara primer ini memiliki dampak negatif bagi kesehatan manusia. 
Tabel 1 Toksisitas relatif polutan udara (Babcock,1971 dalam Fardiaz 1992)

\begin{tabular}{cccc}
\hline \multirow{2}{*}{ Polutan } & \multicolumn{2}{c}{ Level toleransi } & \multirow{2}{*}{ Toksisitas relatif } \\
\cline { 2 - 3 } & $\mathrm{Ppm}$ & $\mu \mathrm{g} / \mathrm{m}^{3}$ & \\
\hline CO & 32,0 & 40.000 & 1,00 \\
\hline HC & & 19.300 & 2,07 \\
\hline SOx & 0,50 & 1430 & 28,00 \\
\hline NOx & 0,25 & 514 & 77,80 \\
\hline Partikel & & 375 & 106,70 \\
\hline
\end{tabular}

Jenis polutan yang paling berbahaya bagi kesehatan manusia, berdasarkan tingkat toksisitasnya, yaitu partikel, kemudian diikuti nitrogen oksida $\left(\mathrm{NO}_{\mathrm{x}}\right)$, belerang oksida $\left(\mathrm{SO}_{\mathrm{x}}\right)$, hidrokarbon $(\mathrm{HC})$, dan yang terakhir karbon monoksida (Fardiaz, 1992). Karbon monoksida merupakan kelompok polutan yang paling rendah toksisitasnya.

Zat pencemar udara dapat berbentuk gas pencemar, yaitu antara lain nitrogen oksida $\left(\mathrm{NO}_{\mathrm{x}}\right)$, belerang oksida $\left(\mathrm{SO}_{\mathrm{x}}\right)$ dan karbon monoksida. Jenis gas pencemar udara tersebut dihasilkan dari proses pembakaran bahan bakar kendaraan bermotor. Selain gas pencemar, zat pencemar udara dapat juga berbentuk partikel. Partikel (particulate) secara sempit dapat diartikan sebagai pencemar berbentuk padatan. Partikel dapat juga diartikan sebagai suatu bentuk pencemaran udara yang berasal dari zarah-zarah kecil yang terdispersi ke udara, baik berupa padatan, cairan ataupun padatan dan cairan secara bersama-sama, yang dapat mencemari lingkungan (Wardhana, 2001). Pencemaran partikel dapat berasal dari peristiwa alami dan juga ulah manusia.

Simond (1978) menyebutkan bahwa sebagian besar polusi disebabkan oleh manusia, terutama dari pembakaran bahan bakar fosil di rumah, pabrik, dan kendaraan bermotor. Rute transportasi dan jalan raya terutama adalah sumber utama dari polusi udara dan suara. Sumber-sumber polusi lain yaitu pembakaran, proses industri, pembuangan limbah, dan lain-lain. Wardhana (2001) menjelaskan sebagian besar zat pencemar udara, yaitu sebanyak 75\%, berasal dari gas buangan hasil pembakaran bahan bakar fosil. Udara daerah perkotaan yang memiliki banyak kegiatan industri dan lalu lintas padat cenderung tidak bersih. 
Tabel 2 Sumber dan persentase emisi polutan mayor (Simonds, 1978)

\begin{tabular}{lccccc}
\hline Sumber emisi & CO (\%) & HC (\%) & Partikulat (\%) & SOx (\%) & NOx (\%) \\
\hline Kendaraan bermotor & 64.8 & 45.7 & 1.0 & 0.9 & 36.5 \\
\hline Pesawat terbang & 1.9 & 1.1 & 0.3 & 0.3 & 1.7 \\
\hline Jalur kereta api & 0.1 & 0.3 & 0.3 & 0.6 & 0.4 \\
\hline Kapal & 1.1 & 0.8 & 0.3 & 0.9 & 0.8 \\
\hline Bahan bakar motor lain & 5.8 & 5.1 & 0.3 & 0.6 & 7.6 \\
\hline Sumber stasioner & 1.2 & 2.4 & 20.4 & 73.0 & 42.1 \\
\hline Proses industri & 7.9 & 14.7 & 41 & 22.5 & 0.8 \\
\hline Limbah buangan & 5.2 & 5.3 & 4.0 & 0.6 & 1.7 \\
\hline Kebakaran hutan & 6.2 & 7.7 & 25.0 & 0.0 & 6.7 \\
\hline Pembakaran pertanian & 5.5 & 4.6 & 6.8 & 0.0 & 1.3 \\
\hline Lainnya & 0.3 & 12.3 & 0.6 & 0.6 & 0.4 \\
\hline Total & 100.0 & 100.0 & 100.0 & 100.0 & 100.0 \\
\hline
\end{tabular}

Pencemaran udara berdampak pada kesehatan manusia. Selain itu, pencemaran udara juga dapat membahayakan mahluk hidup lain seperti hewan dan tanaman. Pencemaran udara juga dapat menyebabkan pemanasan global dan lubang ozon.

\subsection{Sistem Informasi Geografis (SIG)}

Sistem Informasi Geografis adalah suatu sistem yang berbasis komputer yang digunakan untuk menyimpan dan memanipulasi informasi geografis (Aronoff dalam Irianti, 1988). SIG merupakan sistem yang terdiri dari beberapa komponen yaitu perangkat keras komputer, perangkat lunak, data geografi dan personil yang dirancang untuk bekerja secara efisien untuk memperoleh, menyimpan, memperbaharui, memanipulasi, menganalisis dan menampilkan informasi-informasi yang berbasis geografi. Prahasta (2001) menjelaskan bahwa SIG memiliki kemampuan untuk menguraikan unsur-unsur yang terdapat di permukaan bumi ke dalam bentuk beberapa layer atau coverage data spasial. SIG dapat dipalikasikan kepada berbagai bidang keilmuan yang berhubungan dengan sumberdaya alam. Terdapat empat komponen dalam sistem informasi geografi yaitu sebagai berikut :

1. Hardware atau perangkat keras, merupakan wadah berupa komputer sebagai wadah untuk mengoperasikan sistem informasi geografi.

2. Software atau perangkat lunak yang berfungsi untuk menganalisis informasi geografi. 
3. Data, berupa data geografi maupun tabular yang dapat diperoleh melalui pengukuran langsung di lapang maupun data dari citra satelit.

4. Manusia, teknologi SIG tidak dapat berjalan tanpa manusia yang mengatur dan membangun sistemnya. 


\section{BAB III \\ METODOLOGI}

\subsection{Waktu dan Tempat Penelitian}

Penelitian dilakukan kawasan Sentul City, yang terletak di kecamatan Babakan Madang dan kecamatan Sukaraja, kabupaten Bogor, provinsi Jawa Barat. Lokasi penelitian yaitu salah satu jalan utama pada kawasan Sentul City, jalan Mohammad Husni Thamrin, Sentul City, kabupaten Bogor. Penelitian ini dilakukan mulai bulan April 2010 sampai bulan Oktober 2010, dengan kegiatan pengumpulan data, baik lapang maupun sekunder, serta pengolahan data. Penulisan dan penyusunan dilakukan mulai bulan November 2010 sampai Maret 2011.

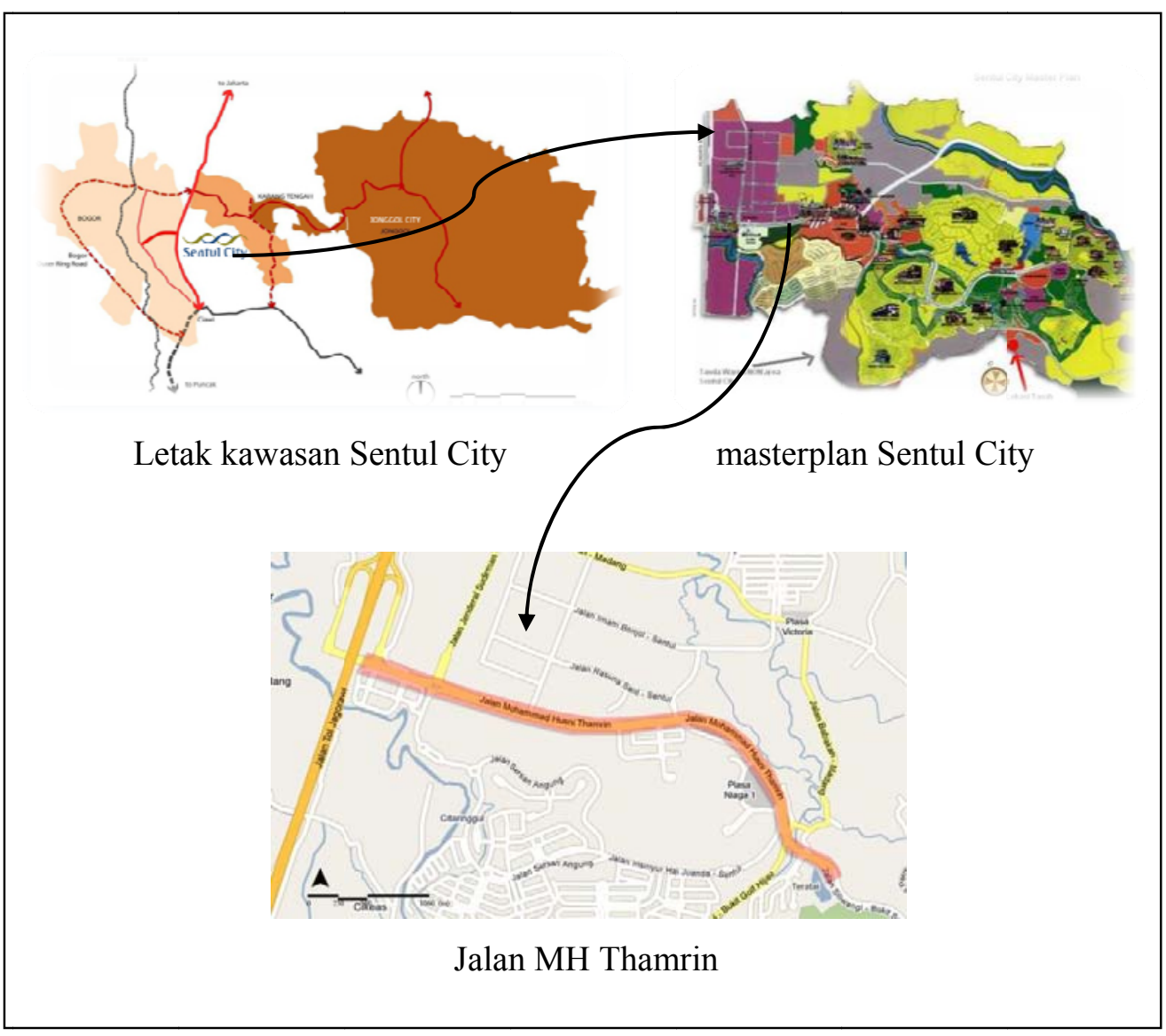

Gambar 5 Lokasi penelitian 


\subsection{Bahan dan Alat}

Bahan dalam penelitian ini berupa data-data, baik primer maupun sekunder. Bahan-bahan yang digunakan untuk penelitian ini yaitu :

1. Peta kawasan Sentul City,

2. data fisik dan biofisik,

3. data tata guna lahan,

4. data titik pohon,

5. data AMDAL,

6. studi pustaka.

Selain menggunakan berbagai bahan yang telah disebutkan, penelitian ini juga menggunakan alat-alat. Alat-alat yang digunakan untuk penelitian ini yaitu :

1. kamera digital,

2. GPS (Global Positioning System),

3. komputer (Personal Computer), dan

4. berbagai software yang menunjang untuk penelitian, antara lain Autocad 2006, Garmin, Arcview 3.2, Microsoft Excel dan Office 2007, dan Photoshop CS2.

\subsection{Metode Penelitian}

Metode yang digunakan dalam penelitian ini adalah metode deskriptif dan analisis spasial. Metode deskriptif digunakan dalam menganalisis dan menilai kondisi serta fungsi ekologis yang diteliti. Analisis spasial digunakan dalam pengolahan data spasial serta menspasialkan hasil penilaian.

Penelitian ini dilakukan untuk mengevaluasi fungsi ekologis jalur hijau jalan untuk menyerap polutan gas dan menjerap partikel. Penelitian ini dilakukan dalam beberapa tahap yaitu (1) tahap persiapan, (2) inventarisasi, (3) analisis, (4) evaluasi dan (5) rekomendasi. Tahap persiapan merupakan tahapan awal yang dilakukan sebelum memulai penelitian dan bertujuan mempersiapkan pelaksanaan penelitian. Tahap inventarisasi merupakan tahap pengumpulan data-data yang menjadi bahan penelitian. Data-data tersebut kemudian dianalisis, diolah dan dinilai pada tahap analisis dan evaluasi. Tahap sistesis merupakan tahapan akhir pada penelitian dimana akan dihasilkan rekomendasi. 


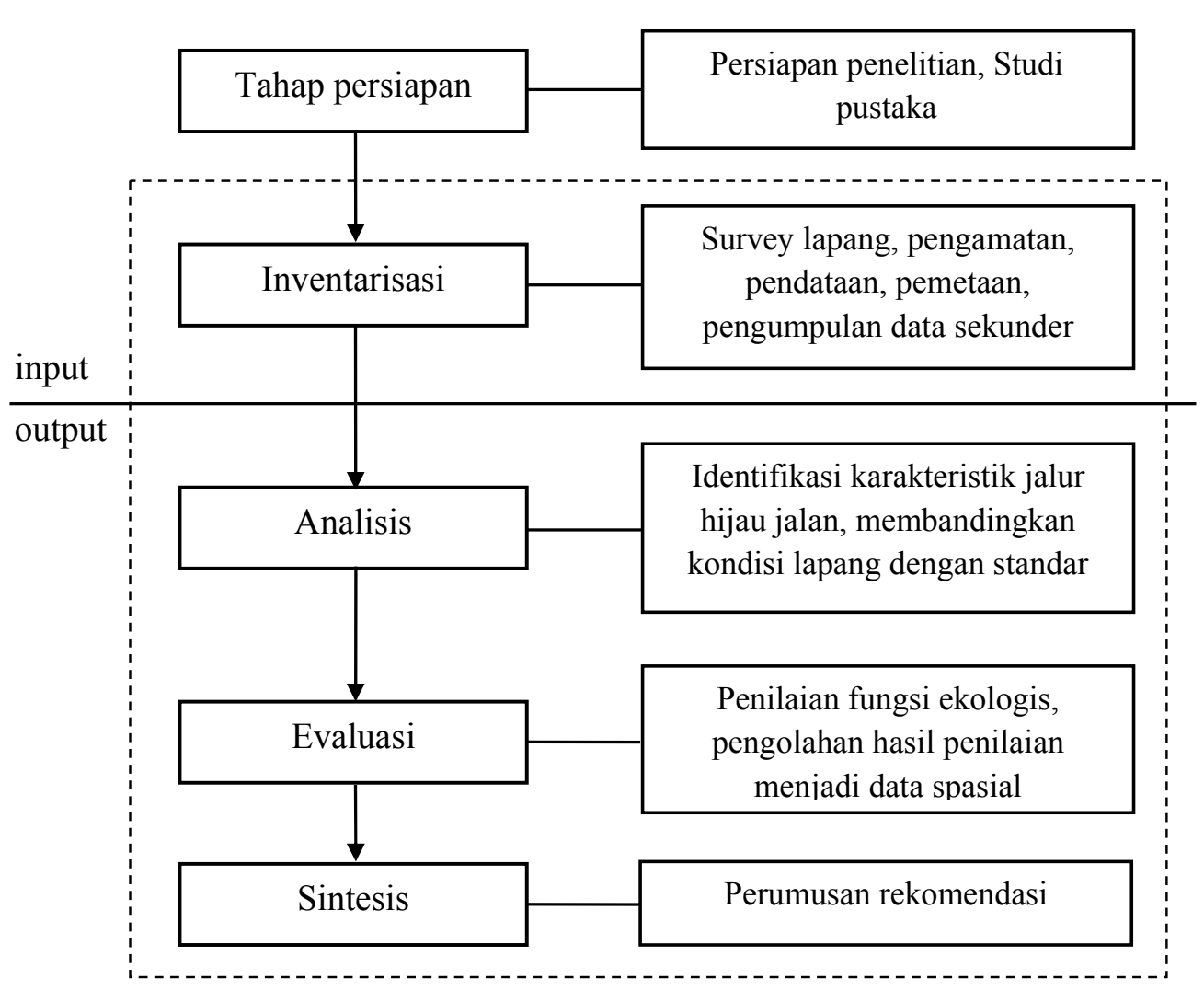

Gambar 6 Bagan tahap penelitian

\section{Tahap persiapan}

Pada tahap persiapan dilakukan berbagai hal untuk mempersiapkan pelaksanaan penelitian. Kegiatan-kegiatan yang dilakukan pada tahapan persiapan meliputi merumuskan usulan penelitian, pemilihan lokasi serta penyusunan proposal penelitian. Selain itu, dilakukan juga presentasi usulan penelitian dan pengurusan izin-izin penelitian.

Pada tahap ini juga dilakukan studi pustaka terhadap berbagai literatur. Studi literatur dilakukan untuk mendapatkan standar dan kriteria ruang terbuka hijau yang ideal untuk fungsi yang diteliti yaitu fungsi ekologis ruang terbuka hijau dalam mereduksi polusi dan menjerap partikel. Standar dan karakteristik hasil studi literatur tersebut digunakan sebagai bahan pembanding untuk penilaian fungsi ekologis jalur hijau jalan. Standar tersebut berupa karakteristik vegetasi yang dapat memenuhi fungsi ekologis untuk pereduksi polutan dan penjerap partikel. 


\section{Inventarisasi}

Inventarisasi dilakukan untuk memperoleh gambaran lengkap tentang kondisi tapak. Pada tahap inventarisasi dilakukan pengumpulan data-data yang digunakan untuk penelitian. Data-data tersebut berupa data primer dan data sekunder. Data primer pada penelitian ini merupakan data-data hasil observasi/pengamatan langsung di lapang. Data sekunder didapatkan dari studi literatur dan dari sumber-sumber terkait.

Kegiatan yang dilakukan di lapang berupa observasi lapang lokasi penelitian yaitu jalur hijau jalan MH Thamrin. Observasi lapang dilakukan untuk mendata jenis vegetasi dan jumahnya serta mengidentifikasi karakteristik jalur hijau jalan MH Thamrin. Selain itu, dilakukan juga pengambilan foto kondisi eksisting lokasi penelitian dengan kamera digital. Selanjutnya dilakukan juga pemetaan vegetasi jalur hijau jalan $\mathrm{MH}$ Thamrin dengan menggunakan GPS (Global Positioning System). Pemetaan dilakukan untuk mengetahui posisi vegetasi, persebaran serta jumlahnya. Jenis vegetasi yang dipetakan dibatasi pada jenis pohon dengan tinggi minimal $2 \mathrm{~m}$ atau lebih dari itu. Selain kegiatan lapang, dilakukan juga wawancara dengan pihak pengelola Sentul City untuk mendapatkan informasi-informasi yang berkaitan dengan penelitian. Kegiatankegiatan lapang menghasilkan data primer untuk penelitian ini.

Selain mengumpulkan data primer, dilakukan juga pengumpulan data sekunder. Pengumpulan data sekunder antara lain melalui studi pustaka dan pengambilan data pada sumber-sumber terkait seperti pengelola Sentul City dan Badan Meteorologi dan Geofisika. Data sekunder yang digunakan pada penelitian ini antara lain data-data tentang aspek fisik dan biofisik, data iklim, data baku mutu kualitas udara, peta kawasan, dan standar-standar untuk fungsi ekologis yang diteliti hasil studi literatur.

Tahap inventarisasi dilakukan untuk mendapatkan berbagai informasi dan data yang diperlukan untuk mendukung penelitian. Data-data yang dihasilkan dari tahap inventarisasi dijabarkan pada tabel berikut. 
Tabel 3 Jenis data hasil inventarisasi

\begin{tabular}{|c|c|c|c|c|}
\hline No. & Jenis Data & Parameter & Bentuk & Sumber \\
\hline 1. & Letak geografis & $\begin{array}{l}\text { Batas, luas wilayah, } \\
\text { akses }\end{array}$ & Data sekunder & $\begin{array}{l}\text { Pengelola Sentul } \\
\text { City, literatur }\end{array}$ \\
\hline 2. & Tata guna lahan & $\begin{array}{l}\text { Pola penggunaan } \\
\text { lahan }\end{array}$ & $\begin{array}{l}\text { Data primer dan } \\
\text { sekunder }\end{array}$ & $\begin{array}{l}\text { Survey lapang, } \\
\text { pengelola Sentul City }\end{array}$ \\
\hline 3. & $\begin{array}{l}\text { Geologi, } \\
\text { topografi, tanah }\end{array}$ & $\begin{array}{l}\text { Topografi, jenis dan } \\
\text { struktur tanah, } \\
\text { struktur geologi }\end{array}$ & $\begin{array}{l}\text { Data primer dan } \\
\text { sekunder }\end{array}$ & $\begin{array}{l}\text { Survey lapang, } \\
\text { pengelola Sentul City }\end{array}$ \\
\hline 4. & Iklim & $\begin{array}{l}\text { Suhu, curah hujan, } \\
\text { kelembaban }\end{array}$ & Data sekunder & BMG \\
\hline 5. & Vegetasi & $\begin{array}{l}\text { Jenis pohon, jumlah, } \\
\text { luas, letak, kondisi } \\
\text { lapang }\end{array}$ & $\begin{array}{l}\text { Data primer dan } \\
\text { sekunder }\end{array}$ & $\begin{array}{l}\text { Survey lapang, } \\
\text { pengelola Sentul City }\end{array}$ \\
\hline 6. & Kualitas udara & $\begin{array}{l}\text { Jenis zat pencemar, } \\
\text { jumlah zat pencemar, } \\
\text { baku mutu }\end{array}$ & Data sekunder & Pengelola Sentul City \\
\hline 7. & Sosial ekonomi & Fasilitas, pengguna & $\begin{array}{l}\text { Data primer dan } \\
\text { sekunder }\end{array}$ & $\begin{array}{l}\text { Survey lapang dan } \\
\text { pengelola Sentul City }\end{array}$ \\
\hline 8. & $\begin{array}{l}\text { Standar fungsi } \\
\text { ekologis jalur } \\
\text { hijau jalan }\end{array}$ & $\begin{array}{l}\text { Karakteristik } \\
\text { tanaman untuk } \\
\text { menyerap polutan } \\
\text { dan menjerap partikel }\end{array}$ & Data sekunder & Literatur \\
\hline 9. & Jalan & $\begin{array}{l}\text { Lokasi, dimensi, } \\
\text { elemen pembentuk } \\
\text { jalan, tata hijau, } \\
\text { jumlah kendaraan }\end{array}$ & $\begin{array}{l}\text { Data primer, } \\
\text { sekunder }\end{array}$ & $\begin{array}{l}\text { Survey lapang, } \\
\text { pengelola sentul city, } \\
\text { studi literatur }\end{array}$ \\
\hline
\end{tabular}

\section{Analisis}

Pada tahap ini dilakukan analisis terhadap data-data yang didapatkan pada hasil inventarisasi. Analisis dilakukan secara deskriptif. Dari hasil inventarisasi kondisi lapang jalur hijau jalan, dilakukan analisis untuk mengidentifikasi karakteristik jalur hijau jalan tersebut. Analisis dilakukan antara lain dengan membandingkan kondisi lapang dengan standar untuk mengetahui kelebihan dan kekurangan jalur hijau jalan. Jenis vegetasi jalur hijau jalan yang telah 
diinventarisasi, diidentifikasi jenis-jenis yang diketahui toleran dan dapat menyerap pencemar gas atau menjerap partikel berdasarkan studi pustaka. Analisis juga dilakukan terhadap kualitas udara dengan baku mutu udara ambien untuk mengetahui kondisi kualitas udara kawasan. Analisis dilakukan untuk mengetahui kondisi atau tingkat pencemaran dalam kawasan dan juga fungsi ekologis jalur hijau jalan untuk mereduksi polusi dan menjerap partikel.

Selain analisis deskriptif, dilakukan analisis spasial dengan bantuan GIS. Analisis spasial dilakukan untuk data inventarisasi jalur hijau jalan dari pemetaan dengan GPS. Data tersebut dianalisis untuk mengidentifikasi dan mengetahui sebaran jenis vegetasi pada jalur hijau jalan.

\section{Evaluasi}

Pada tahap evaluasi, dilakukan penilaian fungsi ekologis jalur hijau jalan. Fungsi ekologis yang dievaluasi pada penelitian ini yaitu fungsi ekologis untuk mengurangi polusi udara, yang kemudian dibagi menjadi fungsi menyerap polutan gas dan menjerap partikel. Fungsi menyerap polutan gas dan menjerap partikel dibedakan berdasarkan mekanisme tanaman dalam mengurangi zat pencemar tersebut. Evaluasi bertujuan mengetahui fungsi ekologis jalur hijau jalan secara kuantitatif dan kualitatif.

Penilaian dilakukan terhadap kondisi lapang jalur hijau jalan dengan perbandingan standar idealnya yang didapatkan melalui studi pustaka. Penilaian dilakukan terhadap elemen pohon pada jalur hijau jalan, terutama pohon-pohon pada tepi jalan, median dan traffic islands. Penilaian dilakukan dengan membandingkan ciri fisik serta kondisi lapang vegetasi pada jalur hijau jalan dengan kriteria-kriteria yang dikumpulkan dari berbagai sumber pustaka, untuk fungsi ekologis yang diamati. Aspek fungsi jalur hijau jalan yang diamati yaitu fungsi jalur hijau jalan dalam menyerap polutan gas dan menjerap partikel.

Vegetasi atau pohon jalur hijau jalan yang diinventarisasi pada pengamatan lapang dibandingkan dengan ciri fisik serta karakter sesuai kriteria penilaian untuk fungsi menyerap polutan gas dan menjerap partikel. Kriteria penilaian untuk fungsi menyerap polutan gas dan menjerap partikel dijelaskan pada tabel berikut. 
Tabel 4 Kriteria penilaian fungsi ekologis

\begin{tabular}{|c|c|}
\hline Aspek fungsi pohon & Kriteria penilaian \\
\hline \multirow[t]{6}{*}{ Penyerap polutan gas } & 1. Kepadatan tajuk \\
\hline & 2. Terdiri atas beberapa lapis tanaman dan terdapat kombinasi \\
\hline & dengan semak, perdu dan groundcover. \\
\hline & 3. Daun tipis \\
\hline & 4. Jumlah daun banyak \\
\hline & 5. Jarak tanam rapat \\
\hline \multirow[t]{5}{*}{ Penjerap partikel padat } & $\begin{array}{l}\text { 1. Struktur permukaan, tepi daun kasar, berlekuk, } \\
\text { berbulu/bertrikoma }\end{array}$ \\
\hline & 2. Daun jarum atau daun lebar \\
\hline & 3. Tajuk rimbun dan rapat \\
\hline & 4. Tekstur kulit batang dan ranting kasar, ranting berduri \\
\hline & 5. Kepadatan ranting \\
\hline
\end{tabular}

Sumber : Carpenter et al (1975), Dahlan (2004), Dahlan (1989), Ernawati (2003), Grey dan Deneke (1978), Hidayat (2008), Nasrullah (2001), Patra (2002), Taihuttu (2001)

Penilaian dilakukan untuk tiap jenis pohon. Untuk masing-masing kriteria, diberikan penilaian dengan nilai antara 1 hingga 4 berdasarkan kesesuaian ciri fisik dan kondisi lapang pohon dengan kriteria penilaian, dimana nilai 1 berarti tidak sesuai, 2 berarti kurang sesuai, 3 berarti sesuai, dan 4 berarti sangat sesuai dengan kriteria penilaian. Nilai maksimal atau nilai ideal untuk tiap kriteria adalah 4. Nilai yang didapat dari tiap kriteria dijumlahkan kemudian dibandingkan dengan jumlah ideal atau nilai maksimum dari tiap kriteria penilaian. Hasil perbandingan kemudian diubah ke dalam bentuk persen untuk mendapatkan persentase nilai evaluasi.

Nilai evaluasi $=\frac{\text { Jumlah total kriteria penilaian }}{\text { Jumlah total nilai ideal kriteria penilaian }} \times 100 \%$

Dari penilaian tersebut didapatkan hasil penilaian dalam bentuk persentase. Hasil penilaian tersebut kemudian dikelompokkan dalam empat kategori penilaian yaitu sangat sesuai, sesuai, kurang sesuai, tidak sesuai. Pengelompokkan hasil penilaian menggunakan 5 selang dimana nilai bobot sempurna yaitu $100 \%$ dibagi menjadi 5 selang sama besar, sebesar $20 \%$. Untuk 
penelitian ini, selang $40 \%$ terendah dikelompokkan dalam satu kategori tidak sesuai. Pembobotan 40\% terendah untuk kategori tidak sesuai ditujukan untuk meningkatkan standar penilaian (Hidayat, 2008). Pengelompokan persentase pembobotan aspek fungsi jalur hijau jalan adalah sebagai berikut :

sangat baik/sangat sesuai bila $>80 \%$ kriteria terpenuhi, baik/sesuai bila $61-80 \%$ kriteria terpenuhi, kurang baik/kurang sesuai bila 41 - $60 \%$ kriteria terpenuhi, dan buruk/tidak sesuai bila $\leq 40 \%$ kriteria terpenuhi.

Setelah dilakukan penilaian terhadap jalur hijau jalan, didapatkan nilai kuantitatif dan kualitatif dari vegetasi jalan untuk fungsi ekologis yang diteliti serta pengelompokkannya seperti telah disebutkan sebelumnya. Hasil penilaian kemudian diolah menjadi data spasial untuk menggambarkan sebaran vegetasi serta luasnya untuk tiap kategori vegetasi. Pengolahan secara spasial tersebut dilakukan dengan bantuan GIS (Geographic Information System). Hasil dari pengolahan dengan GIS berupa data spasial daerah-daerah ruang terbuka hijau jalan yang berdasarkan penilaian sudah ataupun belum berfungsi ekologis dengan baik.

\section{Sintesis}

Tahap sintesis merupakan tahap akhir dari evaluasi fungsi ekologis jalur hijau jalan yang akan menghasilkan suatu rekomendasi. Rekomendasi yang diberikan terutama peningkatan kualitas jalur hijau jalan sebagai penyerap polutan gas serta penjerap partikel pada lanskap jalan Sentul City. Rekomendasi diberikan dalam bentuk deskriptif. Rekomendasi diharapkan dapat menjadi bahan masukan bagi pihak pengelola Sentul City dalam pengembangan lanskap jalan pada kawasan Sentul City. 


\section{BAB IV KONDISI UMUM}

\subsection{Sejarah Kawasan}

Kawasan Sentul City awalnya direncanakan sebagai kawasan wisata agro dengan luas lahan 1300 ha. Lahan seluas 1300 ha tersebut terdiri dari 1100 ha tanah bekas PTP IX Pasir Maung dan 200 ha lahan yang diperoleh melalui pembebasan tanah milik masyarakat setempat. Kawasan wisata agro tersebut akan dikembangkan menjadi kawasan hunian dan wisata yang bernuansa pertanian dengan penutupan bangunan yang rendah (KWT 10\%) dengan nama Royal Sentul Highlands. Di dalam kawasan tersebut akan dibangun perumahan, rumah kebun, berbagai fasilitas olahraga dan rekreasi.

Seiring berkembangnya kawasan DKI Jakarta dan Bogor, permintaan pasar cenderung menguat ke arah permintaan rumah tinggal. Hal tersebut menyebabkan pengelola kawasan mempertimbangkan perubahan rencana pembangunan kawasan. Kawasan Royal Sentul Highlands yang awalnya direncanakan sebagai kawasan wisata agro diubah dan dikembangkan menjadi kawasan permukiman kota. Luas kawasan yang awalnya 1300 ha mengalami penambahan lahan seluas 1165 ha sehingga luas total kawasan menjadi 2465 ha. Selain itu, kawasan wilayah terbangun yang awalnya 10\% naik menjadi 30\%.

Perumahan Bukit Sentul tersebut terletak pada batas kawasan seluas 3001,4 ha. Di dalam batas kawasan tersebut terdapat hutan lindung seluas 116,4 ha dan kawasan permukiman penduduk seluas 419,7 ha yang tidak akan dibebaskan. Seiring berubahnya perencanaan pengembangan kawasan, pengelola kawasan juga turut mengalami perubahan menjadi PT Bukit Sentul Tbk.

Sejak perusahaan didirikan hingga sekarang telah terjadi beberapa kali perubahan nama dan struktur organisasi perusahaan. Nama perusahaan yang berlaku saat ini yaitu, PT Sentul City Tbk., mulai diberlakukan pada Juli 2006. 


\subsection{Kondisi Fisik dan Biofisik}

\subsubsection{Letak, luas, dan aksesibilitas}

Permukiman Sentul City adalah sebuah kawasan kota pegunungan dengan luas 2465 ha dan terletak pada batas kawasan seluas 3001,4 ha. Kawasan ini terletak di sebelah timur kota Bogor dan dikembangkan oleh PT Sentul City Tbk.

Kawasan Sentul City berada di dua kecamatan yaitu kecamatan Babakan Madang dan kecamatan Sukaraja. Kawasan Sentul City mencakup 8 desa, yaitu desa Babakan Madang, desa Sumurbatu, desa Cijayanti, desa Citaringgul, desa Bojongkoneng, desa Cipambuan, desa Kadumanggu di kecamatan Babakan Madang dan desa Cadasngampar di kecamatan Sukaraja. Kawasan permukiman Sentul City dikelilingi oleh beberapa gunung yaitu Gunung Pangrango, Gunung Pancar, Gunung Paniisan, Gunung Liang, Gunung Garangsang, Gunung Salak, dan Gunung Hambalang. Kawasan ini juga dilalui aliran Sungai Citeureup, Sungai Cikeas, Sungai Citaringgul, dan Sungai Cijayanti. Batas kawasan Sentul City adalah sebagai berikut.

Batas utara : Desa Cipambuan, Desa Cijayanti, dan Desa Kadungmangu

Batas timur : Desa Hambalang dan Desa Karang Tengah

Batas selatan : Desa Nanggrak

Batas barat $\quad$ : Desa Cijayanti, Desa Cikeas, dan Desa Cadas Ngampar

Kawasan permukiman Sentul City merupakan kawasan strategis di selatan Jakarta karena terdapat akses langsung ke dalam kawasan dari jalan tol Jagorawi (Jakarta-Bogor). Kawasan permukiman Sentul City berjarak 45 km dari jembatan Semanggi, Jakarta. Selain melalui jalan tol, terdapat pula akses lain menuju kawasan, yaitu melalui kompleks perumahan Bogor Baru menuju desa Cimahpar kemudian ke desa Cijayanti yang berjarak 13 km dengan kondisi jalan yang sudah beraspal.

\subsubsection{Topografi}

Kawasan Sentul City merupakan perbukitan bergelombang sedang yang terletak di dalam suatu cekungan yang dibatasi oleh punggungan bukit yang sekaligus menjadi batas daerah tadah (catchment area) dari S. Cikeas dan S. Citeureup. Kawasan Sentul City mempunyai kemiringan lereng dari hampir datar 
sampai sekitar $60^{\circ}$, dan ketinggian antara 250-600 mdpl (AMDAL Bukit Sentul, 2000). Di dalam batas kawasan permukiman seluas 3001,4 Ha, selain perumahan, juga terdapat 419,7 ha dusun/kampung yang tidak akan dibebaskan dan 116,4 ha hutan lindung.

Kawasan ini memiliki topografi yang berbukit-bukit dengan kemiringan lereng mulai dari $0 \%$ sampai 45\%. Bagian utara permukiman ini berupa punggungan dengan keadaan relatif datar dan kemiringan lerengnya 3-8\% atau 25\%. Kemiringan lembah sungai yang ada berkisar 8-15\% dan sebagian lagi berkisar 15-25\%. Terdapat juga bagian terjal dengan kemiringan 25-45\%, dengan kondisi kemiringan tanah yang demikian, gejala erosi dengan intensitas ringan sampai sedang tampak terjadi di beberapa tempat.

Kondisi topografi dipertahankan dengan meminimalisasi kegiatan gali dan timbun (cut and fill) sehingga jalan dan rumah dibangun mengikuti kontur, termasuk juga jalan lokasi penelitian yaitu Jalan MH Thamrin. Bentukan yang mengikuti topografi menghasilkan jalan yang berkelok-kelok dan rumah yang terletak di atas jalan (up slope) dan di bawah jalan (down slope).

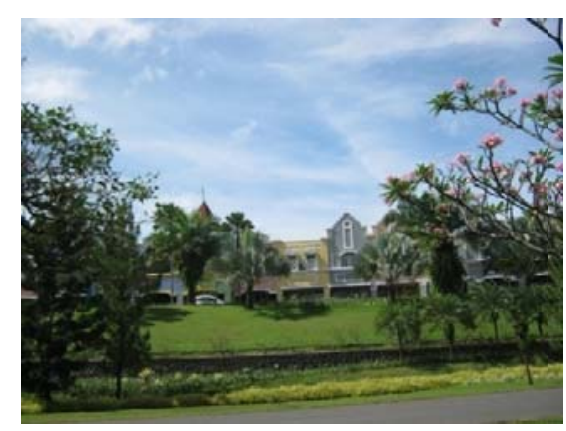

Gambar 7 Bentukan bangunan di atas jalan

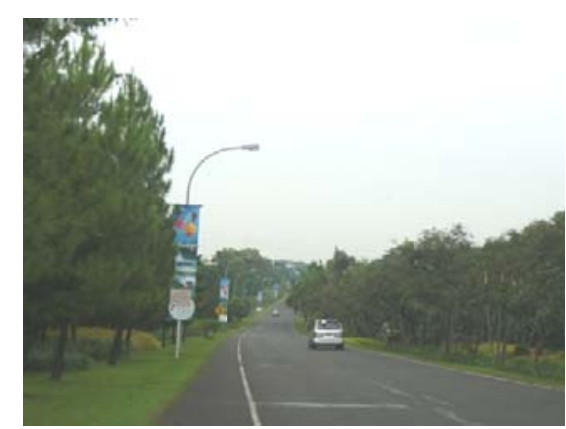

Gambar 8 Topografi pada jalan $\mathrm{MH}$ Thamrin

\subsubsection{Tata guna lahan}

Tata guna lahan kawasan Sentul City terdiri atas beberapa macam penggunaan lahan seperti perumahan, perdagangan, fasilitas komersial, serta sarana dan prasarana. Sarana dan prasarana dibagi menjadi beberapa jenis penggunaan lahan yaitu fasilitas khusus, jalan, interchange, kawasan hijau, dan fasilitas sosial dan fasilitas umum. Fasilitas yang bersifat pelayanan untuk 
penghuni dalam kawasan terbagi menjadi dua yaitu fasilitas sosial dan fasilitas umum yang dibangun oleh pemerintah daerah serta sarana untuk berbagai kegiatan sosial dan umum seperti tempat rekreasi dan olahraga yang dibangun oleh pengelola kawasan. Sarana sosial, ekonomi dan umum yang ada bersifat memberikan pelayanan pusat kawasan dan pelayanan pusat lingkungan. Pusat kawasan berlokasi di jalan masuk dan pusat lingkungan tersebar pada cluster yang ada.

Luas lahan efektif sekitar 2465 ha dan dimanfaatkan untuk perumahan dan berbagai fasilitasnya. Lahan yang tidak efektif adalah lahan dengan kemiringan lereng lebih dari 40\%. Proporsi pembagian lahan dalam kawasan untuk tiap peruntukkan dapat dilihat pada tabel di bawah ini.

Tabel 5 Peruntukkan kawasan perumahan Sentul City

\begin{tabular}{|c|c|c|c|c|c|c|c|}
\hline \multirow[t]{2}{*}{ No } & \multirow[t]{2}{*}{ Rencana peruntukkan } & \multirow{2}{*}{$\begin{array}{l}\text { Luas } \\
\text { efektif } \\
\text { (ha) }\end{array}$} & \multirow[t]{2}{*}{ Prosentase (\%) } & \multirow[t]{2}{*}{ Keterangan } & \multicolumn{2}{|c|}{$\begin{array}{l}\text { Wilayah } \\
\text { terbangun }\end{array}$} & \multirow[t]{2}{*}{$\begin{array}{l}\text { KWT } \\
\text { (\%) }\end{array}$} \\
\hline & & & & & $\begin{array}{l}\text { KDB } \\
(\%)\end{array}$ & $\begin{array}{l}\text { Luas } \\
\text { (ha) }\end{array}$ & \\
\hline 1 & Perumahan & 1098,90 & $45 \%$ & Area & 35 & 383 & 16 \\
\hline 2 & $\begin{array}{l}\text { Perdagangan, } \\
\text { perkantoran dan industry } \\
\text { ringan *) }\end{array}$ & 189,50 & $8 \%$ & $\begin{array}{l}\text { saleable } \\
1479,00\end{array}$ & 56 & 106 & 4 \\
\hline 3 & $\begin{array}{l}\text { Fasilitas khusus } \\
\text { (komersial) }\end{array}$ & 190,60 & $8 \%$ & & 12 & 24 & 1 \\
\hline 4 & Sarana prasarana & & & & & & \\
\hline & $\begin{array}{ll}- & \text { Fasilitas } \\
& \text { khusus }\end{array}$ & 36,10 & $40 \%$ & $\begin{array}{l}\text { Area non } \\
\text { saleable }\end{array}$ & 7 & 3 & 0 \\
\hline & - Jalan & 561,70 & $23 \%$ & 986,00 & 36 & 204 & 8 \\
\hline & $\begin{array}{ll}\text { - } & \text { Interchange }\end{array}$ & 15,00 & $1 \%$ & & 60 & 9 & \\
\hline & - $\quad$ Hijau & 323,00 & $13 \%$ & & & & \\
\hline & $\begin{array}{ll}- & \text { Fasos dan } \\
& \text { fasum }\end{array}$ & 50,30 & $2 \%$ & & 18 & 9 & 0 \\
\hline & Total & 2465,00 & $100 \%$ & 2465 & & 737 & 30 \\
\hline
\end{tabular}

Bangunan hunian akan terdiri atas jenis rumah biasa dan apartemen, yang ditempatkan sebagai kelompok-kelompok hunian (clusters). Keseluruhannya akan 
terdiri dari 53 kluster, dengan jumlah total rumah yang akan dibangun seluruhnya mencapai 22.220 unit dan perkiraan jumlah total penghuni sekitar 88.881 orang. Jumlah ini diperkirakan menjadi lebih besar pada saat semua fasilitas komersial, sarana sosial, dan sarana umum beroperasi. Diperkirakan jumlah total akan mencapai 150 ribu orang.

\subsubsection{Iklim}

Berdasarkan data iklim Badan Meteorologi dan Geofisika (BMG) Darmaga, Bogor, diketahui suhu, kelembaban, kondisi penyinaran matahari, dan angin kawasan. Data-data iklim tersebut dijabarkan pada tabel berikut.

Tabel 6 Data iklim tahun 2009

\begin{tabular}{|c|c|c|c|c|c|c|}
\hline \multirow[b]{2}{*}{ Bulan } & \multirow{2}{*}{$\begin{array}{c}\text { Temperatur } \\
\text { Rata-rata } \\
\text { suhu } \\
\text { bulanan } \\
\left({ }^{\circ} \mathrm{C}\right) \\
\end{array}$} & \multirow{2}{*}{$\begin{array}{c}\text { Kelembaban } \\
\text { Rata-rata } \\
\text { kelembaban } \\
\text { bulanan (\%) }\end{array}$} & \multicolumn{2}{|c|}{ Penyinaran Matahari } & \multicolumn{2}{|c|}{ Angin } \\
\hline & & & $\begin{array}{c}\text { Lama } \\
\text { penyinaran } \\
\text { (\%) }\end{array}$ & $\begin{array}{c}\text { Intensitas } \\
\left(\text { Joule/cm }^{2} \text { ) }\right.\end{array}$ & $\begin{array}{l}\text { Kecepatan } \\
\text { (Knots) }\end{array}$ & Arah \\
\hline Januari & 25.0 & 88 & 37 & 223 & 2.9 & W \\
\hline Februari & 25.1 & 88 & 29 & 254 & 3.5 & $\mathrm{~W}$ \\
\hline Maret & 25.8 & 82 & 73 & 240 & 2.9 & $\mathrm{~W}$ \\
\hline April & 26.2 & 82 & 65 & 257 & 2.3 & $\mathrm{~W}$ \\
\hline Mei & 26.1 & 85 & 67 & 254 & 2.2 & W \\
\hline Juni & 26.1 & 81 & 78 & 253 & 2.1 & $\mathrm{~W}$ \\
\hline Juli & 25.8 & 77 & 90 & 272 & 2.4 & $\mathrm{~W}$ \\
\hline Agustus & 26.3 & 75 & 91 & 317 & 2.4 & W \\
\hline September & 26.6 & 75 & 90 & 355 & 2.7 & W \\
\hline Oktober & 26.0 & 82 & 74 & 356 & 2.4 & W \\
\hline November & 26.3 & 81 & 55 & 315 & 2.6 & $\mathrm{~W}$ \\
\hline Desember & 26.1 & 85 & 56 & 201 & 2.3 & W \\
\hline JUMLAH & 311.4 & 981.5 & 806.6 & 3297.0 & 30.7 & \\
\hline Rata-rata & 26.0 & 81 & 67.2 & 274.8 & 2.6 & \\
\hline
\end{tabular}

Sumber : Stasiun Klimatologi Dramaga

Suhu rata-rata bulanan dari bulan Januari 2009 sampai Desember 2009 adalah $26^{\circ} \mathrm{C}$ dengan suhu tertinggi sebesar 26,6 $6^{\circ} \mathrm{C}$ pada bulan September 2009 dan suhu terendah sebesar $25^{\circ} \mathrm{C}$ pada bulan Januari 2009. Kelembaban rata-rata kawasan dari Januari 2009 sampai Desember 2009 adalah 81\% dengan kelembaban tertinggi pada bulan Januari dan Februari 2009 sebesar 88\% dan kelembaban terendah sebesar 75\% pada bulan Agustus 2009. 
Lama penyinaran matahari rata-rata dari bulan Januari 2009- Desember 2009 adalah 67,2 \% dengan intensitas penyinaran matahari rata-rata sebesar 275 joule/ $\mathrm{cm}^{2}$. Lama penyinaran maksimum terjadi pada bulan Juli dan September 2009 sebesar 90\% dan terendah pada bulan Februari 2009 sebesar 29 \%. Kecepatan angin rata-rata pada bulan Januari 2009 - Desember 2009 sebesar 2,6 knots dengan arah angin ke arah barat. Kecepatan angin maksimum terjadi pada bulan Februari 2009 sebesar 3,5 knot dan terendah pada bulan Juni 2009 sebesar 2,1 knots.

\subsubsection{Geologi}

Berdasarkan AMDAL Bukit Sentul (2000), batuan penyusun daerah studi dikelompokkan dalam tiga satuan, yaitu satuan batu lempung, satuan batu volkanik dan satuan endapan alluvial. Satuan batu lempung terhampar cukup luas di bagian barat dan bagian tengah kawasan Sentul City. Satuan batu lempung terdiri dari batu lempung dan batu lanau gampingan yang memiliki kemiringan perlapisan antara 40-65 ${ }^{\circ}$ dan mempunyai banyak struktur kekar. Di beberapa tempat terutama di lembah sungai, membentuk morfologi yang cukup curam.

Batuan volkanik terdapat pada bagian barat dan timur kawasan Sentul City. Di bagian barat, satuan batuan volkanik terdapat dalam bentuk lapisan tipis tuf pasiran dengan ketebalan 4-6 meter yang sebagian besar telah melapuk menjadi lempung, lanau atau lanau lempungan berwarna kecoklatan. Di bagian timur, satuan batuan volkanik terdiri dari breksi dan lava. Bagian permukaan batuan telah mulai melapuk menjadi pasir lempungan dan lanau lempungan. Tebal satuan di bagian timur sekitar $6 \mathrm{~m}$ dan menebal kearah selatan.

Satuan endapan alluvial terdapat di bagian utara kawasan, terutama pada lembah sungai yang lebar dan berkelok (meander). Batuan tersusun dari lanau, pasir, kerikil dan bongkah andesit yang bersifat lepas sampai belum padu. Tebal satuan kurang dari 5 meter. Batuan-batuan tersebut umumnya telah melapuk menjadi lempung, lempung lanauan dan pasir serta pasir lempungan.

Struktur geologi yang terdapat di kawasan ini adalah pelipatan dan kekar serta tidak ditemukan sesar atau patahan. Berdasarkan kondisi morfologi kawasan 
dan sifat fisik batuannya, kawasan ini tergolong daerah rawan gerakan tanah (AMDAL Bukit Sentul, 2000).

\subsubsection{Tanah}

Berdasarkan AMDAL Bukit Sentul tahun 2000, pada kawasan Sentul City terdapat lima jenis tanah. Kelima jenis tanah itu adalah Typic Hapluduit, Typic Distropept, Oxic Dystropept, Typic Hamitnopept dan Aquic Dystropept. Penilaian status kesuburan tanah di kawasan Sentul City menunjukkan bahwa tanah di daerah studi mempunyai tingkat kesuburan tanah yang rendah kecuali pada jenis Aquic Dystrotept yang mempunyai kesuburan sedang. Secara umum kelima jenis tanah tersebut memiliki kapasitas tukar kation (KTK) dan kejenuhan basa (KB) serta kandungan $\mathrm{P}_{2} \mathrm{O}_{5}$ dalam tanah yang rendah dan sangat rendah, serta kandungan bahan organik yang tergolong rendah sampai sedang. Kondisi ini menyebabkan tanah di kawasan ini sangat miskin hara, sehingga kesuburan tanah rendah. Status kesuburan tanah pada kelima jenis tanah ini dapat dilihat pada tabel berikut ini.

Tabel 7 Status kesuburan tanah

\begin{tabular}{lllllll}
\hline No. & Klasifikasi & KTK & KB & $\mathrm{P}_{2} \mathrm{O}_{5}$ & Organik & Kesuburan \\
\hline 1. & Typic Hapluduit & $\mathrm{S}$ & $\mathrm{R}$ & $\mathrm{SR}-\mathrm{R}$ & $\mathrm{S}$ & $\mathrm{R}$ \\
\hline 2. & Typic Dystropept & $\mathrm{S}$ & $\mathrm{SR}-\mathrm{R}$ & $\mathrm{SR}-\mathrm{R}$ & $\mathrm{S}$ & $\mathrm{R}$ \\
\hline 3. & Oxic Dystropept & $\mathrm{R}-\mathrm{S}$ & $\mathrm{SR}-\mathrm{R}$ & $\mathrm{SR}$ & $\mathrm{R}-\mathrm{S}$ & $\mathrm{R}$ \\
\hline 4. & Typic Hamitnopept & $\mathrm{R}$ & $\mathrm{SR}$ & $\mathrm{SR}$ & $\mathrm{S}-\mathrm{T}$ & $\mathrm{R}$ \\
\hline 5. & Aquic Dystropept & $\mathrm{S}$ & $\mathrm{S}$ & $\mathrm{S}$ & $\mathrm{S}$ & $\mathrm{S}$ \\
\hline Sumber : AMDAL Bukit Sentul, 2000 & & & & \\
Keterangan: & & & & \\
KTK = kapasitas tukar kation & $\mathrm{SR}=$ sangat rendah & $\mathrm{S}=$ sedang & \\
KB = Kejenuhan basa & $\mathrm{R}=$ rendah & $\mathrm{T}=$ tinggi
\end{tabular}

Tanah Typic Hapluduit mempunyai kecepatan infiltrasi yang rendah dengan kapasitas memegang air yang cukup baik sehingga tanah cenderung basah, aliran permukaan (run off) tinggi dan tanah sulit diolah pada lokasi yang berlereng. Kandungan $\mathrm{P}_{2} \mathrm{O}_{5}$ sangat rendah akibat adanya fiksasi fosfor yang tinggi sedangkan kandungan bahan organiknya sedang dan ditemukan pada kedalaman 

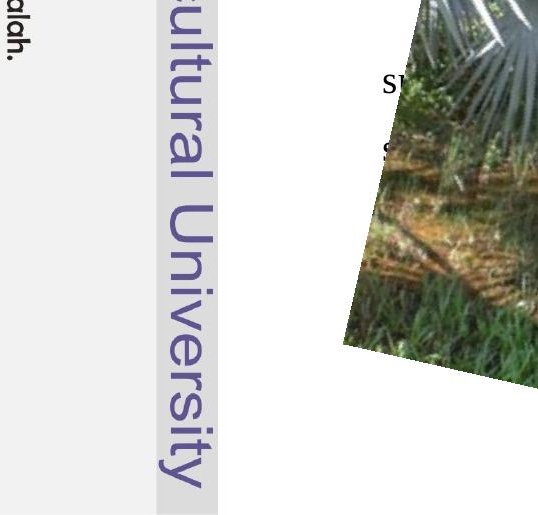
Kualitas air sungai Citeureup dan Cikeas secara umum masih berada di bawah ambang batas Baku Mutu Air Golongan B (PP No 20 tahun 1990) kecuali untuk air sungai Citeureup yang mengalir di tengah kawasan permukiman telah menunjukkan adanya beberapa parameter yang melewati ambang batas (AMDAL Bukit Sentul, 2000).

Selain air sungai, terdapat pula air tanah dan mata air. Air tanah yang terdapat pada kawasan ini tersedia dalam bentuk air tanah bebas (air tanah dangkal) yang tidak bertekanan dengan kedalaman muka air tanah antara 4-12 m. Potensi air tanah ini kecil dan dipengaruhi oleh musim. Mata air kecil dan rembesan banyak ditemukan di luar desa/kampung. Debit air dari mata air ini umumnya sangat kecil. Kualitas air pada mata air masih berada di bawah ambang batas Baku Mutu Air Gol. B (PP No. 20 th 1990), kecuali untuk mangan. Pemanfaatan air tersebut lebih lanjut perlu dilakukan penyaringan dan aerasi.

Kawasan Sentul City dibangun pada kawasan yang miskin air, baik air permukaan maupun air tanah. Kebutuhan air pada kawasan Sentul City dipenuhi dari air sungai, air hujan dan air danau. Sungai Cikeas dan Citeureup menjadi cadangan (make up water) pemasok kebutuhan air di kawasan ini terutama ketika musim kemarau untuk mengairi dua danau yang terdapat di kawasan, selain dari hasil tampungan air hujan. Kawasan Sentul City telah mendapatkan SIPA (Surat Izin Pengambilan Air) dari Gubernur Kepala Daerah Tingkat I Jawa Barat untuk memanfaatkan air dari Sungai Citeureup dan Sungai Cikeas.

Untuk kebutuhan air minum, penyiraman tanaman dan pembersihan jalan, dipenuhi dengan menampung air hujan dan air danau pada waduk (reservoir) L1 dan L2 untuk dijadikan sumber air baku. Untuk keperluan air minum ini telah dibangun tempat khusus pengolahan air dan ditangani oleh departemen khusus yaitu Water Treatment Plant Departement.

Air baku untuk air minum bersumber di sungai Citeureup, air hujan dan air danau ditampung pada waduk L1 yang berkapasitas 1,4 juta $\mathrm{m}^{3}$. Air dari waduk kemudian dialirkan ke unit pengolah air minum dan didistribusikan ke rumahrumah. Air untuk menyiram taman dan pembersihan jalan ditampung pada kolam L2 dengan kapasitas 250 ribu $\mathrm{m}^{3}$ dengan volume air yang dapat dimanfaatkan 200 ribu $\mathrm{m}^{3}$. Air tersebut kemudian diangkut dengan menggunakan mobil tangki air 
untuk menyiram tanaman dan pembersihan jalan di seluruh kawasan permukiman Sentul City (AMDAL Bukit Sentul, 2000).

\subsubsection{Vegetasi}

Vegetasi asli yang terdapat di sekitar kawasan dapat digolongkan menjadi vegetasi hutan, vegetasi kebun campuran, vegetasi tegalan, vegetasi semak belukar, dan vegetasi sawah. Vegetasi hutan, kebun campuran, dan tegalan merupakan bentuk vegetasi yang mendominasi kawasan pada musim penghujan, sedangkan pada musim kemarau vegetasi semak belukar merupakan bentuk yang mendominasi. Vegetasi sawah mendominasi daerah pinggir sungai sedangkan yang lainnya mendominasi daerah lahan kering.

Berdasarkan kondisi topografi, geologi dan tanahnya, kawasan Sentul City memiliki dua bentang alam utama, yaitu bentang alam alluvial serta daerah kering dengan topografi bergelombang sampai bukit terjal. Bentang alam alluvial dicirikan oleh persawahan sedangkan bentang alam lahan kering ditutupi oleh berbagai bentuk vegetasi yaitu kebun campuran, vegetasi tegalan, vegetasi semak belukar dan vegetasi hutan di daerah puncaknya.

Bentang alam alluvial berada di daerah aliran sungai Citeureup pada daerah banjir mulai dari Babakan Madang sampai ke Karang Tengah sedangkan sistem lembah dengan teras berada di arah Leuwi Goong dan daerah hulunya. Vegetasi pada kawasan banjir dengan sistem teras antara lain padi (Oryza sativa), pisang (Musa paradisiaca), talas (Colocasia esculenta), ketela pohon (Manihot utilisima), kacang tanah (Vigna sp) dan tanaman budidaya lainnya. Tanaman lain antara lain berbagai jenis tanaman dari suku Cyperaceae, yaitu Fimbristylis aestivalis, Scirpus spp, Cyperus alternifollius, dan dari suku Poaceae yaitu rumput gagajahan atau Panicum crusgalli dan Panicum repens, dan juga Amaranthus spinossus, Alternanthera phyloxeroides, Commelina mudiflora, Yussiena repens, dan Yussiena linifolia.

Bentang alam kering terdiri dari beberapa jenis tutupan vegetasi yaitu vegetasi hutan, vegetasi kebun campuran, vegetasi tegalan, dan vegetasi semak belukar. Selain itu terdapat pula vegetasi halaman rumah (pekarangan). 
Kebun campuran banyak ditemui pada daerah dekat perumahan, menyebar di daerah dengan topografi bergelombang sampai berbukit. Tanaman yang terdapat pada kebun campuran antara lain tanaman langka gandaria (Bouea macrophylla) dan beberapa jenis tanaman buah-buahan langka seperti sempur (Sandoricum koetjape), jamlang (Syzigium cumini), samolo (Diospyros discolor), kupa atau gohok (Syzigium polycephalum). Selain itu, terdapat juga berbagai tanaman buah yang umum ditemui, di antaranya rambutan (Nephelium lapaceum), duku (Lansium duccu), cempedak (Artocarpus cempeden), nangka (Artocarpus heterophylla), nona (Anona reticulata), sirsak (Anona muricata), srikaya (Anona squamosa), durian (Durio zybethinus), manggis (Garcinia mangostana), jambu air (Syzigium aquaeum), jambu bol (Syzigium malacense), jambu batu (Psidium guajava), alpukat (Persea americana), kedondong (Spondias dulce) dan lainnya.

Vegetasi tegalan dominan pada berbagai tempat dengan topografi bergelombang. Tegalan umumnya ditanami ketela pohon atau singkong (Manihot utilisima) dan tanaman palawija lainnya seperti cabai (Capsicum annuum), tomat (Lycopersicum esculentum), kacang panjang (Vigna $s p$ ) dan lainnya. Beberapa tanaman liar yang banyak ditemui di tegalan antara lain Mimosa invisa, Mimosa pudica, Mimosa pigra, Bidens pilosus, Borreria laevis, Borreria alata, Leucas lavandulifolia, Pueraria sp, Centrosema pubescens, Sida acuta, Sida rhombifolia dan Rostelularia sandana.

Hutan berada di daerah bertopografi berbukit terjal, terutama pada bagian puncaknya. Bentuk vegetasi berupa hutan alami dan hutan binaan, termasuk kawasan hutan Gunung Pancar. Hutan binaan didominasi oleh pinus atau tusam (Pinus merkusii) berada di kawasan hutan wisata yang berbatasan langsung dengan kawasan Sentul City. Di hutan binaan, yaitu hutan wisata Gunung Pancar, selain tusam terdapat berbagai jenis tumbuhan lain, seperti Piper aduncum, Piper sarmentosum, Diplazium esculentum, Blechnum capense, Selaginella sp, Dicranopteris linearis, Clerodendrum seratum, Caladium bicolor, Clibadium surinemense, Derris ecliptica, Pandanus furcatus, Rubus molucanus, dan rumput Rottboelia exxaltata.

Semak belukar merupakan bentuk vegetasi yang banyak dijumpai pada musim kemarau. Tumbuhan yang dominan yaitu kirinyuh (Eupatoium 
inuliifolium), kiseureuh/seuseureuhan (Piper aduncum), saliara (Lantana camara), rumput alang-alang (Imperata cylindrica) dan sulanjana (Hierochloa horsfieldii). Tumbuhan lain yang biasa tumbuh yaitu Melastoma malabathricum, Ageratum conyzoides, Polygala paniculata, Paspalum conyugatum, Mikania corata, Sentrosema pubescens, Lygodium circinatum, Tetracera scandens, Rostelularia sundana, Emilia sonchifolia, Panicum repens, Lycopodium cernuum, dan jenis tumbuhan liar lainnya.

\subsubsection{Satwa}

Secara umum fauna yang ditemui di lokasi proyek beragam, namun tidak dijumpai fauna langka atau dilindungi berdasarkan undang-undang. Berdasarkan AMDAL Bukit Sentul (2000) tercatat sebanyak 42 spesies yang terdiri dari 7 spesies amfibi, 7 spesies reptil, 22 spesies aves, dan 6 spesies mamalia dijumpai di kawasan Sentul City.

Jenis amfibi yang paling umum dijumpai di kawasan Sentul City, terutama di sekitar sawah, semak tepi sungai, tepi kolam, dan parit, yaitu kodok budug (Bufo melanostictus), kodok budug sungai (Bufo asper), katak tegalan (Fejervarya limnocharis) dan katak kolam (Rana chalconota). Reptil yang umum dijumpai di berbagai tipe habitat alami seperti ladang/kebun dan sawah yaitu kadal (Mabuya multifasciata). Sementara itu, cicak (Hemidactylus frenatus) ditemui di sekitar rumah dan biawak (Varanus salvator) banyak dijumpai pada bagian pinggir danau yang bersemak atau berumput tinggi.

Pada jenis burung, burung layang-layang (Collocalia esculenta), burung gereja (Passer montanus) ditemukan di berbagai tipe habitat. Burung dari family Apodidae dan Hirundinidae banyak dijumpai di sekitar sungai Cijayanti, dan di sekitar sungai Citeureup. Burung family Sylvidae seperti perenjak, dan cinenen, dan Nectaridae, seperti burung madu, banyak dijumpai pada habitat semak dan belukar yang bervegetasi kirinyuh (Eupatorium spp), saliara (Lantana camara), bungur (Lagestromia japonica), serta di pohon berdaun kupu-kupu (Bauhinia spp). Jenis lain seperti Prinia sp. dijumpai pada bagian pinggir danau yang bersemak atau berumput tinggi. Pada daerah sekitar kebun, semak belukar, dan 
persawahan ditemukan jenis burung pemakan biji-bijian seperti burung pipit (Lonchura leucagastroides) dan Lonchura punctata.

Kelompok mamalia yang ditemui di kawasan ini sangat terbatas. Mamalia yang ada di kawasan ini antara lain mamalia yang sengaja dipelihara oleh penduduk seperti kambing, domba, kucing, serta jenis garangan (Herpestes javanicus) yang dijumpai di sekitar semak belukar. Sejenis mamalia pemakan ikan, Sero (Lutra cinerea), ditemukan di bagian pinggir danau buatan di sekitar lapangan golf. Di sekitar hutan wisata Gunung Pancar dijumpai berbagai kelompok hewan, antara lain burung toed (Lanius sach), elang (Spilornis sp), burung raja udang (Halcyon chloris), babi (Sus sp), ular sanca (Phyton sp).

Selain jenis-jenis tersebut, dijumpai juga berbagai jenis ikan yang umumnya terdapat di daerah sungai yaitu sidat (Anguila sp), kehkel (Gliptosternum sp), beunteur (Puntius binotatus), impun (Poecilia reticulata), bogo (Ophiocephalus sp), lele (Clarias sp), dan ikan nila (Tilapia nilotica). Beberapa jenis ikan lainnya sengaja ditanam di kolam diantaranya ikan mas (Cyprinus carpio) dan ikan mujair (Tilapia mosambica). Belut (Monopterus albus) dijumpai di area persawahan.

\subsection{Kondisi Sosial Ekonomi}

Secara umum, permukiman di kecamatan Citeureup dan Sukaraja terbagi atas dua kategori permukiman yaitu permukiman tidak terencana dan permukiman terencana. Permukiman terencana umumnya tumbuh dalam dalam dua sampai tiga dekade terakhir, yang dibangun dalam beberapa tipe yaitu tipe sederhana, menengah, dan mewah. Permukiman tak terencana yaitu perkampungan penduduk. Pemukiman penduduk setempat masuk ke dalam kategori perumahan tidak terencana, cenderung berkesan perkampungan desa dan memiliki pola yang secara umum memanjang. Rumah-rumah di perkampungan bervariasi dari yang sangat sederhana sampai yang terkesan mewah. Kondisi perumahan terencana dan perkampungan memiliki perbedaaan yang mencolok baik dari bangunannya maupun kelengkapan fisiknya.

Sasaran kawasan Sentul City yaitu kalangan menengah atas. Karena itu, di dalam kawasan Sentul City masyarakat penghuninya sebagian besar berasal dari 
kalangan menengah ke atas. Saat ini, di kawasan Sentul City dan sekitarnya terdapat perbedaan kondisi sarana dan prasarana yang cukup ekstrim. Kondisi sarana dan prasarana yang tidak lengkap terdapat di permukiman masyarakat setempat. Sementara itu, kondisi yang memperlihatkan sarana dan prasarana yang lengkap dan baik terdapat di kawasan permukiman Sentul City.

Untuk kawasan sekitar Sentul City, berdasarkan data monografi desa 1998 dalam AMDAL Bukit Sentul (2000), mata pencaharian utama masyarakat di desadesa dalam dan sekitar kawasan Sentul City adalah sektor pertanian. Setelah pertanian, perdagangan dan jasa merupakan mata pencaharian yang banyak dimiliki oleh penduduk desa. Masyarakat desa dalam dan sekitar kawasan Sentul City tidak hanya melakukan satu jenis pekerjaan saja tetapi juga beberapa pekerjaan dapat dilakukan oleh satu keluarga dan kombinasi mata pencaharian dapat berubah tergantung kemampuan dalam bidang dan jenis pekerjaan tertentu serta hasil yang didapatkan.

Sebagian besar penduduk Babakan Madang dan kecamatan Sukaraja adalah penganut agama Islam dengan jumlah nominal lebih dari 90\%. Sementara sebagian kecil penduduk desa Cijayanti dan Bojongkoneng menganut agama Katholik sejumlah 1,25\% dan penganut Protestan sejumlah 2,2\%. Penduduk dari kesembilan desa tersebut sebagian besar berpendidikan tamat SD/sederajat. Selain itu, terdapat pula penduduk dengan tingkat pendidikan tamat SLTP/sederajat, tamat SLTA/sederajat, serta tamat perguruan tinggi.

\subsection{Jalan MH Thamrin}

\subsubsection{Lokasi dan dimensi}

Jalan MH Thamrin bersama dengan jalan Siliwangi merupakan bagian dari jalan utama kawasan Sentul City. Jalan MH Thamrin meliputi daerah ruang terbuka (open space) yang berawal dari simpang susun tol Bukit Sentul sampai pintu gerbang Siliwangi. Jalan MH Thamrin memiliki panjang sekitar $3 \mathrm{~km}$. Sementara itu, jalan Siliwangi berawal dari gerbang Siliwangi sampai Taman Budaya.

Jalan MH Thamrin berada pada wilayah desa Cipambuan, desa Babakan Madang, dan desa Citaringgul. Luas lahan jalan ini sekitar 16,3 ha dan pengerjaan 
konstruksi jalannya pada tahun 1995 (PT Sentul City Tbk, 2009). Jalan MH Thamrin sebagai salah satu jalan utama kawasan termasuk tipe jalan dengan daerah milik jalan 19 (D-M-J 19). Jalan MH Thamrin terdiri dari dua jalan yang masing-masing mempunyai lebar perkerasan $9 \mathrm{~m}$ dan dipisahkan median berupa jalur hijau sejauh $12 \mathrm{~m}$. Seperti halnya kawasan Sentul City yang secara umum memiliki topografi yang bergelombang, topografi jalan utama juga terdiri dari perbedaan ketinggian yang beragam.

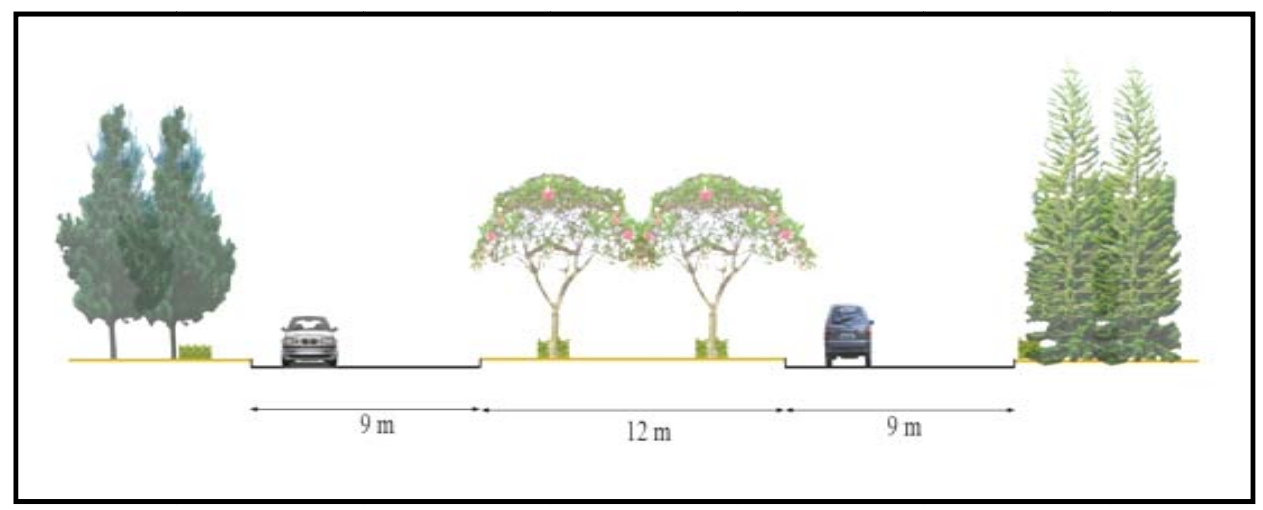

Gambar 10 Dimensi jalan MH Thamrin

Jalan utama pada kawasan Sentul City menghubungkan seluruh areal permukiman dalam kawasan. Sirkulasi jalan utama saat ini hanya dikhususkan pada sirkulasi kendaraan yang menghubungkan jalan utama dengan jalan kolektor. Sirkulasi dibuat dua jalur untuk menjamin keamanan pengguna jalan mengingat kecepatan rata-rata kendaraan yang melintasi jalan utama yaitu sekitar 70 km/jam. Antara jalan utama dengan jalan kolektor dihubungkan dengan daerah persimpangan berupa pertigaan jalan, perempatan jalan dan bundaran jalan. Jalan utama berhubungan erat dengan jalan kolektor karena letak dan fungsinya yang yang saling menunjang dan melengkapi kegiatan pemakai jalan.

\subsubsection{Elemen Pembentuk Jalan}

Elemen pembentuk jalan MH Thamrin antara lain elemen tanaman dan elemen penunjang. Jalan bagi suatu kawasan juga berfungsi sebagai ruang terbuka hijau. Dengan demikian, tanaman menjadi salah satu elemen penting yang membentuk lanskap jalan. Elemen tanaman yang terdapat pada jalan $\mathrm{MH}$ Thamrin 
antara lain pohon, semak, penutup tanah, dan rumput. Elemen tanaman pada suatu lanskap jalan selain memberikan kualitas visual pada jalan juga memiliki fungsifungsi lain seperti pengarah, kontrol polusi, kontrol silau, dan peneduh.

Selain tanaman, terdapat elemen penunjang yang berupa kelengkapan jalan. Elemen penunjang pada jalan $\mathrm{MH}$ Thamrin antara lain saluran drainase, lampu jalan, marka jalan, halte dan pagar pembatas. Contoh elemen penunjang pada jalan MH Thamrin ditunjukkan pada gambar berikut ini.

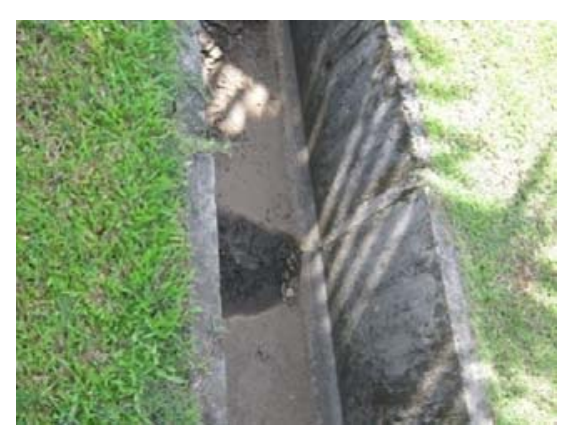

Gambar 11 Saluran drainase

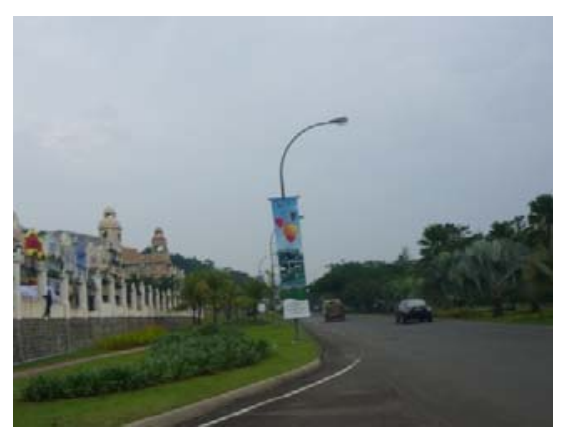

Gambar 12 Lampu jalan

\subsubsection{Tata Hijau Jalan}

Penanaman vegetasi di dalam kawasan Sentul City dilakukan dengan menerapkan peran dari vegetasi yaitu klimatologi, hidrologi, orologi, biologis, estetika, arsitektural, konservasi, rekreasi, dan edukatif. Fungsi-fungsi vegetasi ini diterapkan pada berbagai lokasi di dalam kawasan Sentul City. Peletakan vegetasi disesuaikan dengan kebutuhan fungsi yang diharapkan pada tiap lokasi. Pada lanskap jalan utama, penanaman vegetasi difungsikan terutama sebagai pengarah dan peredam angin (AMDAL Bukit Sentul, 2000).

Tata hijau pada lanskap jalan MH Thamrin didominasi oleh penanaman pohon pinus (Pinus merkusii) dan cemara Norfolk (Araucaria heterophylla). Kedua jenis tanaman ini dipilih terutama untuk memberikan suasana pegunungan pada jalan. Selain kedua jenis pohon tersebut terdapat jenis-jenis pohon lain yaitu pohon berkayu, pohon berbunga, dan palem-paleman. Beberapa contoh tanaman tersebut yaitu ki hujan (Samanea saman), dadap merah (Erythrina christagalli), dan kelapa sawit (Elaeis gueenensis). 


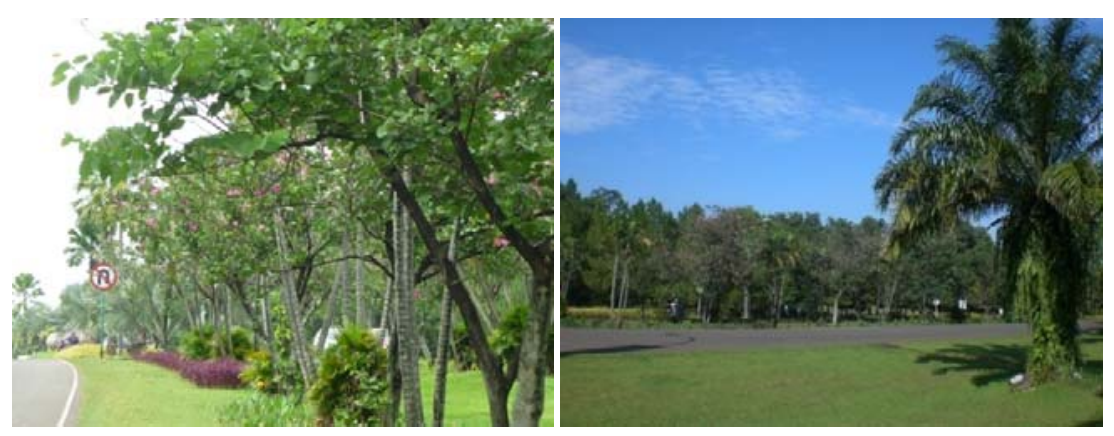

Gambar 13 Tata hijau jalan MH Thamrin

Selain pohon, berbagai jenis elemen tanaman lain turut mengisi tata hijau jalan. Elemen-elemen tanaman tersebut yaitu semak, perdu, groundcover, tanaman merambat, tanaman air, dan rumput. Selain itu, terdapat pula tanaman merambat dan tanaman air. Tanaman merambat dan epifit ditanam di pot-pot, disisipkan pada batang pohon atau ditanam merambati struktur tertentu contohnya merambati tiang lampu jalan. Terdapat juga beberapa jenis tanaman air yang ditanam pada pot-pot. Kombinasi pohon dan semak/perdu dilakukan untuk memaksimalkan fungsi vegetasi lanskap jalan dalam mereduksi bising, menyerap polutan, menjerap partikel, dan screening. Penanaman groundcover dilakukan dengan membentuk pola-pola desain yang menarik di jalan. 


\section{BAB V \\ PEMBAHASAN}

\subsection{Lanskap jalan MH Thamrin}

Penelitian dilakukan pada jalan MH Thamrin, Sentul City, Bogor. Jalan ini merupakan salah satu jalan utama pada kawasan Sentul City. Jalan MH Thamrin memiliki panjang jalan sekitar $3 \mathrm{~km}$, meliputi daerah ruang terbuka dan berawal dari simpang susun Sentul Selatan sampai gerbang Siliwangi. Jalan MH Thamrin dibatasi oleh tol Jagorawi pada bagian utara dan barat. Bagian utara jalan $\mathrm{MH}$ Thamrin juga berbatasan dengan kavling-kavling yang belum dikembangkan. Bagian selatan jalan ini berbatasan dengan kawasan-kawasan komersial dan bisnis. Bagian timur jalan berbatasan dengan Gerbang Siliwangi dan jalan Siliwangi.

Tata guna lahan di sekitar jalan MH Thamrin sebagian besar adalah kawasan komersial dan bisnis serta kavling-kavling yang belum dikembangkan. Kawasan komersial dan bisnis pada Sentul City cukup banyak berada pada jalan utama ini. Beberapa contoh tata guna lahan komersial dan bisnis yang ada di sepanjang jalan ini yaitu Marketing Office Sentul City, kawasan perbelanjaan Bellanova, dan plaza Niaga. Berikut adalah gambar salah satu tata guna lahan yang ada di sekitar jalan MH Thamrin.

Jalan MH Thamrin merupakan jalan dua arah dan terdiri dari dua jalur kendaraan yang dipisahkan oleh satu jalur tanaman. Jalur kendaraan pada jalan ini memiliki lebar sekitar 9 meter. Jalur tanaman sebagai median yang memisahkan kedua jalur kendaraan tersebut memiliki lebar sekitar 12 meter. Jalan MH Thamrin dibentuk mengikuti bentuk topografi kawasan yang bergelombang. 


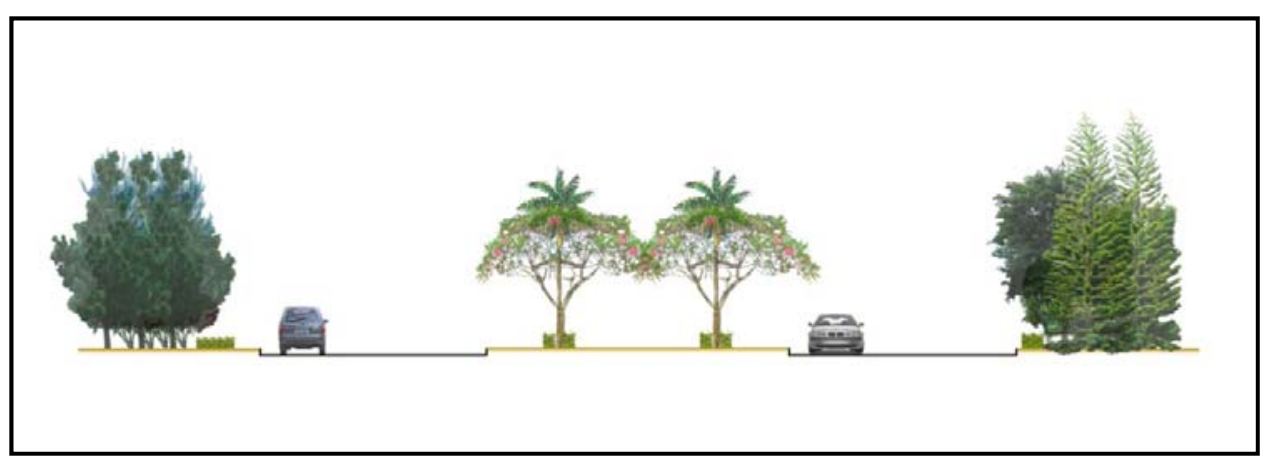

Gambar 14 Tampak potongan jalan MH Thamrin

Jalan MH Thamrin bersama dengan jalan Siliwangi membentuk jalan utama kawasan. Jalan MH Thamrin merupakan akses yang menghubungkan kawasan Sentul City ke tol Jagorawi. Jalan ini juga menghubungkan berbagai bagian pada pemukiman Sentul City. Jalan utama pada kawasan Sentul City terhubung dengan jalan kolektor pada kawasan ini.

Jalan MH Thamrin pada saat ini dikhususkan untuk sirkulasi kendaraan. Jenis kendaraan yang melintas di jalan ini bervariasi, antara lain kendaraan roda dua yaitu sepeda motor dan kendaraan roda empat antara lain mobil, bus dan truk. Kondisi pergerakan kendaraan pada kawasan Sentul City saat ini masih tergolong rendah dan didominansi jenis kendaraan mobil penumpang dan kendaraan kecil lainnya (PT Sentul City Tbk., 2009). Secara umum, lalu lintas jalan ini relatif belum padat.

Kendaraan yang melintas di jalan MH Thamrin sebagian besar merupakan kendaraan penghuni kawasan. Pengguna jalan MH Thamrin merupakan penghuni kawasan Sentul City dan masyarakat di sekitar kawasan Sentul City. Para pengguna menggunakan jalan $\mathrm{MH}$ Thamrin untuk mengakses tol Jagorawi, mendatangi kawasan perdagangan dan komersial di sekitar jalan serta menuju kluster-kluster permukiman dan berbagai area lain di Sentul City.

Saat ini, kawasan Sentul City berada pada tahapan kegiatan operasional dengan sebagian kawasan baru masuk tahap konstruksi dan sebagian lagi masih dalam tahap pra konstruksi. Jumlah unit rumah yang telah terbangun dan beroperasi mencapai 7677 unit. Pada kondisi saat ini, berdasarkan hasil pencatatan pada pintu tol Sentul Selatan, yang merupakan salah satu akses utama untuk 
keluar masuk kawasan, pergerakan kendaraan keluar masuk kawasan masih tergolong rendah (PT Sentul City, 2009). Hal ini mungkin disebabkan karena kawasan masih berkembang dan belum sepenuhnya beroperasi.

Kawasan Sentul City secara keseluruhan direncanakan akan terdiri dari 53 kluster dengan jumlah rumah yang akan dibangun seluruhnya mencapai 22.220 unit (AMDAL Bukit Sentul, 2000). Sasaran kelompok pembeli kawasan ini merupakan kalangan menengah atas. Karena itu, diasumsikan bahwa pada tiap unit penghuni rumah sudah memiliki kendaraan sendiri minimal 1 buah. Dengan demikian, diperkirakan pada kawasan ini sedikitnya akan beroperasi 22.220 unit kendaraan. Dengan demikian, potensi jumlah kendaraan yang akan beroperasi pada kawasan ini cukup tinggi. Walaupun demikian, jumlah pergerakan kendaraan saat ini masih relatif rendah. Kendaraan-kendaraan tersebut akan menggunakan jalan utama MH Thamrin yang merupakan akses utama kawasan menuju tol Jagorawi.

Alat transportasi atau kendaraan bermotor, memiliki beberapa dampak negatif bagi lingkungan sekitarnya, antara lain kebisingan dan polusi udara. Pembakaran bahan bakar pada alat transportasi merupakan salah satu sumber utama pencemar udara. Pembakaran bahan bakar alat transportasi antara lain menimbulkan gas timbal $(\mathrm{Pb})$, oksida karbon $\left(\mathrm{CO}_{\mathrm{x}}\right)$, oksida nitrogen $\left(\mathrm{NO}_{\mathrm{x}}\right)$, dan oksida sulfida $\left(\mathrm{SO}_{\mathrm{x}}\right)$ (Fandeli, 2009). Peningkatan jumlah kendaraan dikhawatirkan akan menambahkan tingkat zat pencemar. Dampak tersebut perlu diperhatikan oleh pengelola kawasan. Dampak polusi udara dapat diminimalkan dengan pengadaan ruang terbuka hijau (RTH).

Jalan MH Thamrin saat ini telah dilengkapi RTH atau taman yang luas dan taman tersebut mendapatkan rekor MURI sebagai taman terluas pada jalan utama. Ruang terbuka hijau memiliki berbagai fungsi ekologis bagi lingkungan salah satunya dapat mengurangi pencemaran udara. Ruang terbuka hijau pada jalan ini diharapkan dapat membantu mengurangi dampak tersebut. Ruang terbuka hijau pada jalan MH Thamrin berupa jalur hijau jalan. 


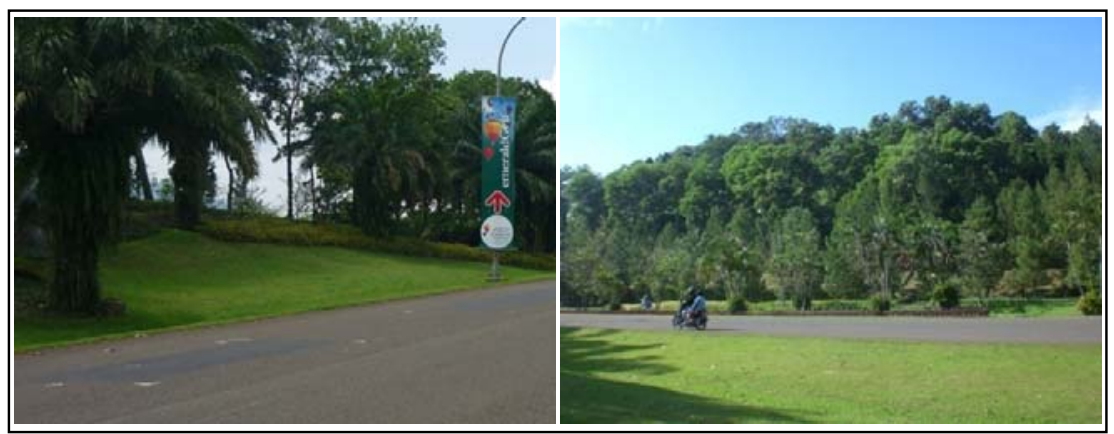

Gambar 15 Ruang terbuka hijau pada jalan utama

\subsection{Identifikasi Karakteristik Jalur Hijau Jalan}

Jalan MH Thamrin merupakan salah satu jalan utama pada kawasan Sentul City. Pada kawasan Sentul City, jalan utama menghubungkan keseluruhan kawasan permukiman Sentul City. Jalan utama merupakan bagian pertama yang dilihat baik oleh penghuni maupun pengunjung. Kesan yang muncul pada jalan utama akan mewakili dan membentuk kesan terhadap keseluruhan kawasan. Lanskap jalan utama pada kawasan ini sangat memperhatikan aspek estetika untuk memberi kesan menarik bagi penghuni atau pengunjung. Jalan $\mathrm{MH}$ Thamrin dilengkapi jalur hijau jalan.

\subsubsection{Bentuk Jalur Hijau Jalan}

Kawasan Sentul City memiliki topografi yang bergelombang. Kondisi topografi kawasan yang bergelombang dipertahankan pada saat mengembangkan kawasan. Jalan MH Thamrin juga dibentuk mengikuti bentuk topografi kawasan yang bergelombang. Beberapa bagian tepi jalan memiliki kemiringan cukup tajam karena terdapat perbedaan ketinggian antara badan jalan dan tepi jalan. Jalur hijau jalan jalan ini juga mengikuti bentuk topografi yang bergelombang. Bentuk topografi yang bergelombang bertujuan untuk menghindari terjadinya genangan air karena sifat tanah kawasan yang kurang dapat menyerap air. Tanah kawasan secara umum miskin hara dan memiliki tingkat kesuburan rendah. Kondisi tanah yang demikian akan mempengaruhi aspek pengolahan tanah dan pemilihan jenis tanaman pada ruang terbuka hijau.

Secara umum, jalur hijau jalan ini ditanami jenis vegetasi yang estetis. Hal ini terutama karena jalan MH Thamrin merupakan jalan utama sehingga aspek 
estetika sangat diperhatikan dan akan mewakili kesan keseluruhan kawasan. Walaupun aspek estetika mendominasi pemilihan vegetasi dan desain penanaman, jalur hijau jalan ini juga ditujukan untuk memenuhi aspek fungsionalnya. Pada lanskap jalan, jalur hijau jalan selain ditujukan untuk menambah nilai visual jalan juga untuk memenuhi beberapa fungsi antara lain fungsi peneduh, penyerap polusi, peredam kebisingan, pemecah angin, pembatas pandang, dan penahan silau lampu kendaraan.

Jalur hijau jalan MH Thamrin merupakan bentuk penyediaan RTH pada jalan kawasan Sentul City. Jalur hijau jalan MH Thamrin merupakan RTH berbentuk jalur. Pola RTH linear mengikuti bentuk jalan. Untuk jalur hijau jalan, RTH dapat disediakan dengan penempatan tanaman antara 20-30\% dari ruang milik jalan sesuai dengan kelas jalan. Jalur hijau jalan MH Thamrin disediakan pada jalur tanaman tepi jalan, median dan taman pulau jalan.

\section{Jalur tanaman tepi jalan}

Penanaman pada tepi jalan merupakan salah satu bentuk penyediaan jalur hijau jalan MH Thamrin. Pada jalur tepi jalan MH Thamrin, vegetasi yang mendominasi yaitu jenis vegetasi berkayu dan berkanopi padat dengan penanaman dalam beberapa lapis tanaman. Dilihat dari jenis vegetasi yang digunakan, penanaman pada tepi sebagian besar ditujukan untuk memaksimalkan aspek fungsi jalur hijau jalan antara lain sebagai peneduh, penyerap polusi udara, peredam kebisingan, pemecah angin, dan pembatas pandang. Selain jenis vegetasi berkayu dan berkanopi padat, terdapat juga jenis-jenis vegetasi estetis pada tepi jalan.

Vegetasi pada jalur penanaman tepi jalan cukup beragam meliputi pohon, perdu, semak, dan groundcover. Pohon-pohon pada tepi jalan umumnya jenis pohon bertajuk padat dan pohon konifer. Pohon konifer, seperti jenis pinus dan cemara, banyak ditanam pada tepi jalan MH Thamrin. Pohon konifer banyak ditanam terutama untuk memunculkan suasana pegunungan pada jalan sesuai dengan konsep kawasan Sentul City sebagai kawasan kota pegunungan.

Bentuk penanaman tepi jalan pada jalan MH Thamrin antara lain penanaman pohon-pohon dalam barisan dan penanaman pohon dengan perdu, 
semak dan groundcover. Penanaman pada tepi jalan terdiri dari beberapa lapis tanaman dan menggabungkan elemen-elemen tanaman dengan ketinggian yang bervariasi, yaitu jenis pohon, perdu, semak, dan groundcover. Penanaman yang berlapis, padat, dan terdiri atas tanaman yang bervariasi dari berbagai ketinggian efektif untuk mengurangi polusi udara dan diperlukan terutama pada jalan karena banyak dilalui kendaraan bermotor. Selain itu, bentuk penanaman ini menambah nilai estetik pada tepi jalan.

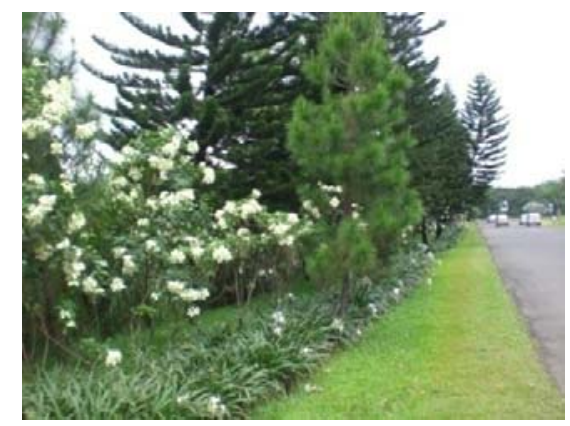

Gambar 16 Penanaman pohon dengan perdu dan semak

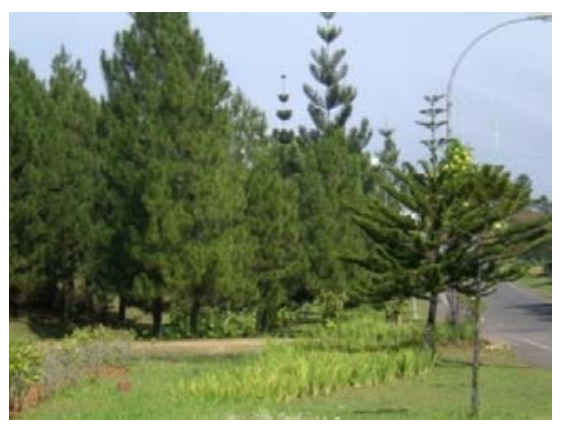

Gambar 17 Penanaman beberapa lapis pohon

Beberapa bagian tepi memiliki topografi yang relatif curam karena adanya perbedaan ketinggian dengan badan jalan. Bentuk topografi yang demikian bertujuan mengurangi kemungkinan terjadinya genangan air dan juga agar penanaman tidak merusak struktur jalan. Bentuk dan penanaman vegetasi pada bagian ini juga mengikuti bentuk topografi yang miring tersebut. Kemiringan lahan dimanfaatkan untuk membuat tapak lebih menarik dengan pemberian pola penanaman dan dibentuk seperti taman. Vegetasi yang ditanam antara lain pohonpohon peneduh, jenis-jenis tanaman palem, serta perdu dan semak. Penanaman pada bentuk taman ini dilengkapi dengan penanaman beberapa semak dan perdu. Selain itu, terdapat juga penggunaan elemen keras seperti seperti batu alam dan batu-batuan lain. Elemen keras tersebut saling melengkapi dengan elemen tanaman dan membentuk taman-taman pada lahan miring. 


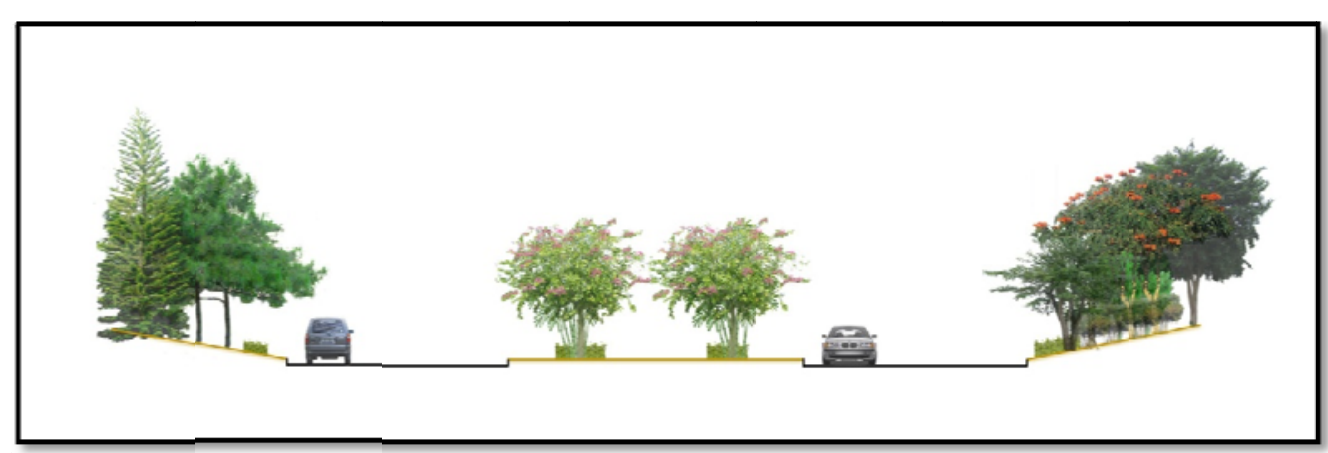

Gambar18 Tepi jalan pada bagian yang miring

Sisi-sisi jalan MH Thamrin berbatasan dengan berbagai penggunaan lahan di sekitar jalan antara lain kavling dan lahan-lahan yang masih dalam pengembangan, kawasan komersial dan perkantoran. Jalur tepi jalan ini turut menyesuaikan dengan penggunaan lahan di sekitarnya. Pada bagian tepi yang berbatasan dengan kawasan komersial dan perkantoran, penanaman vegetasi cenderung lebih terbuka agar tidak menutupi kawasan dan menggunakan berbagai jenis tanaman hias. Jalur hijau jalan, untuk contoh ini, juga berperan dalam menonjolkan dan menambah nilai estetika kawasan di sekitarnya. Jalur tepi yang berbatasan dengan kawasan komersial dan perkantoran menggunakan jenis vegetasi estetis seperti jenis palem-paleman juga pohon dan semak berbunga. Penanaman pada bagian ini juga menggunakan berbagai jenis tanaman penutup tanah dengan pola-pola penanaman yang menarik. Sementara itu, bagian tepi yang berbatasan dengan kavling umumnya menggunakan jenis-jenis pohon peneduh dan penghijauan.

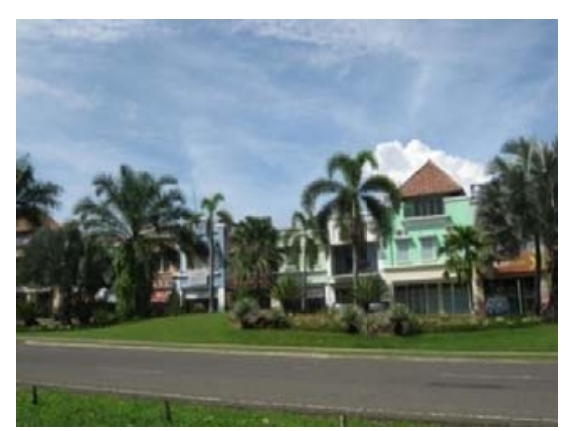

Gambar 19 Tepi jalan pada kawasan komersial

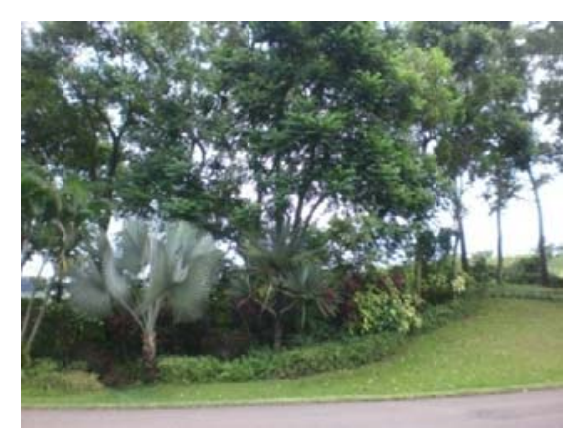

Gambar 20 Penanaman pada tepi jalan yang miring 


\section{Median jalan}

Median merupakan jalur pemisah antara lajur-lajur jalan dan dapat berbentuk taman maupun non taman (Peraturan Menteri Pekerjaan Umum No. 05 Tahun 2008). Pada jalan MH Thamrin, median jalan merupakan bagian dari jalur hijau jalan. Pada jalan MH Thamrin ini, median jalan memisahkan dua lajur kendaraan dan berbentuk taman. Median jalan memiliki pola linear mengikuti bentuk jalan.

Jalur hijau median jalan menggunakan jenis vegetasi pengarah. Fungsi median jalan terutama sebagai pengarah dan menghalau silau. Fungsi median jalan MH Thamrin sebagai pengarah terlihat dari penggunaan tanaman pengarah dan pola penanaman linear yang membentuk arah pandang. Tanaman-tanaman pada median dapat mengurangi silau akibat lampu kendaraan maupun sinar matahari.

Median jalan selain untuk memenuhi aspek fungsional juga dapat menambah nilai keindahan lanskap jalan. Pada jalan MH Thamrin, median terutama lebih menonjolkan aspek estetika tanaman. Jenis tanaman median merupakan jenis vegetasi estetis. Beberapa jenis vegetasi pada median yaitu jenisjenis palem, dan pohon berbunga. Selain jenis pohon, pada median juga ditanam berbagai jenis semak dan groundcover, terutama jenis yang berdaun atau berbunga indah. Penanaman semak dan groundcover pada median umumnya ditanam dengan pola linear pada jarak-jarak antar pohon. Median jalan ini juga dilengkapi dengan pengunaan berbagai elemen keras seperti pot tanaman dan bentuk elemen hias lainnya.

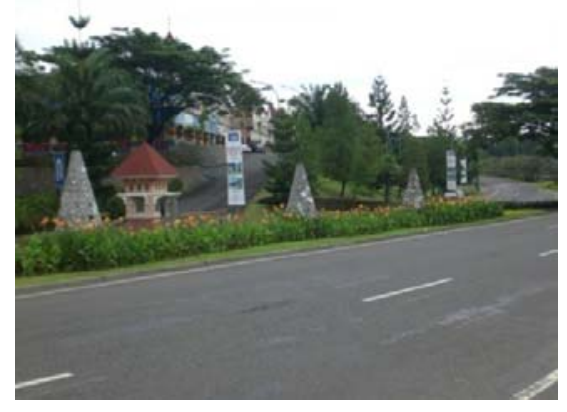

Gambar 21 Penggunaan elemen keras pada median

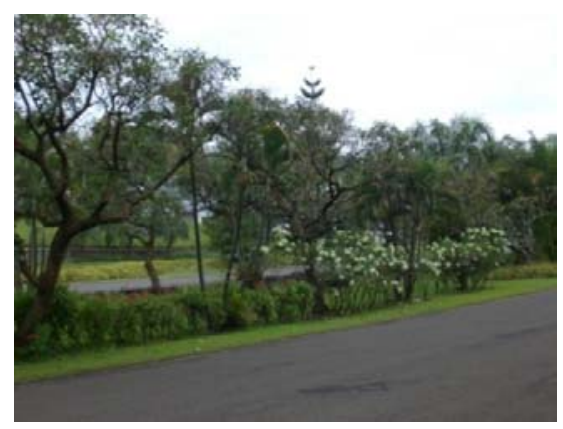

Gambar 22 Penanaman pohon dan semak pada median 


\section{Traffic islands (pulau jalan)}

Selain pada tepi dan median, bagian dari jalur hijau jalan yaitu traffic islands atau pulau jalan. Pulau jalan terbentuk oleh geometris jalan seperti pada persimpangan tiga atau bundaran jalan. Pulau jalan memiliki fungsi sebagai pengarah arus lalu lintas. Pada jalan MH Thamrin terdapat pulau jalan yang terbentuk dari adanya pertemuan antara jalan utama kawasan, yaitu jalan $\mathrm{MH}$ Thamrin, dengan jalan-jalan kolektor kawasan atau terbentuk antara jalur-jalur jalan pada jalan utama.

Pulau jalan pada jalan MH Thamrin umumnya memiliki lahan yang relatif sempit dan diisi penanaman vegetasi peneduh atau pengarah. Selain pohon pengarah dan peneduh, elemen tanaman yang digunakan untuk mengisi pulau jalan antara lain semak pendek atau groundcover. Penanaman semak dan groundcover pada pulau jalan ditujukan agar pandangan pengendara kendaraan tidak terhalang. Pulau jalan berfungsi antara lain untuk mengarahkan arus lalu lintas sehingga diperlukan keleluasaan pandangan untuk melihat arus lalu lintas.

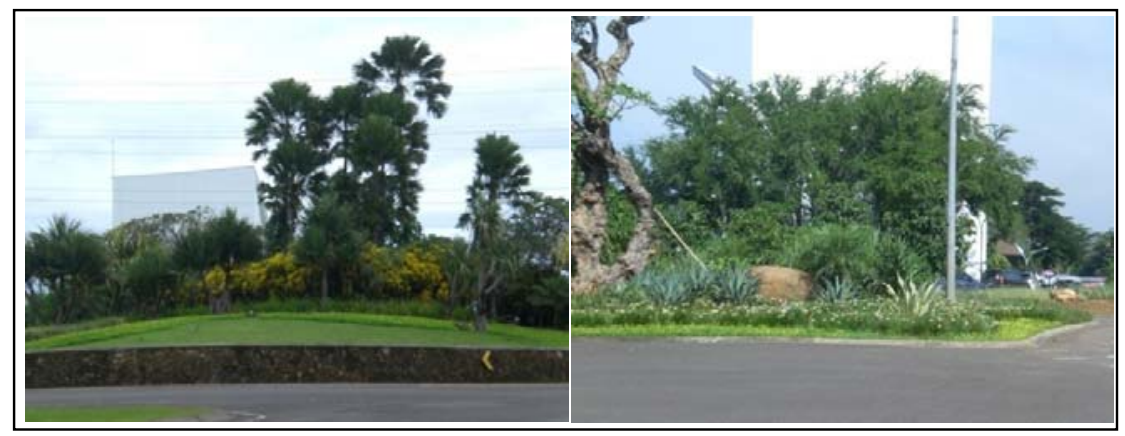

Gambar 23 Traffic islands dan rotunda pada jalan MH Thamrin

Salah satu bentuk pulau jalan antara lain adalah rotunda. Pada jalan $\mathrm{MH}$ Thamrin terdapat rotunda besar yang terbentuk pada persimpangan jalan dan ditinggikan. Berbeda dengan pulau jalan lainnya relatif sempit, rotunda ini cukup besar dan memiliki lahan yang cukup luas. Rotunda ini berperan mengarahkan arus lalu lintas terutama di sekitar kawasan marketing office. Selain mengarahkan arus lalu lintas, rotunda ini juga menjadi focal point pada jalan sehingga fungsi estetisnya cukup dominan. Jenis vegetasi yang digunakan pada rotunda terutama vegetasi estetis. Walaupun demikian, vegetasi pada rotunda ini selain ditujukan 
untuk aspek estetis juga ditujukan untuk fungsional rotunda sebagai pengarah arus lalu lintas jalan. Jenis vegetasi yang digunakan untuk mengisi rotunda ini antara lain jenis pohon pengarah, terutama jenis palem-paleman. Selain pohon, rotunda ini juga ditanami berbagai jenis perdu, semak serta groundcover.

\subsubsection{Identifikasi Jenis Vegetasi Jalur Hijau Jalan}

Secara umum, aspek fungsi estetis lebih mendominasi jalur hijau jalan $\mathrm{MH}$ Thamrin. Hal ini terlihat pada penggunaan vegetasi estetis pada jalur hijau jalan. Walaupun demikian, vegetasi pada jalur hijau jalan $\mathrm{MH}$ Thamrin tidak hanya untuk menciptakan keindahan tapak tetapi juga ditujukan untuk aspek fungsional jalan. Beberapa fungsi vegetasi pada jalan antara lain sebagai pemecah angin dan pengarah. Vegetasi pada lanskap jalan ini juga ditujukan untuk memberikan udara segar dan kontrol polusi.

Penanaman vegetasi pada jalur hijau jalan dilakukan antara lain pada median, traffic island, dan pada jalur tepi jalan. Dari hasil pemetaan dengan GPS, jumlah pohon yang dipetakan mencapai 1889 pohon. Pohon yang dipetakan yaitu pohon dengan tinggi lebih dari $2 \mathrm{~m}$, dan letaknya terutama pada tepi, median atau traffic islands. Pemetaan diutamakan pada pohon-pohon yang letaknya dekat dengan tepi jalan. Selain itu, pemetaan tidak dilakukan pada beberapa lokasi yang curam atau perbatasan jalan dengan daerah luarnya. Berdasarkan hasil observasi lapang, pada jalur hijau jalan MH Thamrin terdapat 32 jenis pohon.

Berbagai jenis pohon pada jalur hijau jalan MH Thamrin antara lain jenis pohon berkayu, pohon berbunga, pohon konifer dan jenis palem. Pohon konifer yang yang ditanam pada jalur hijau jalan ini yaitu pinus (Pinus merkusii) dan cemara Norfolk (Araucaria heterophylla). Pohon berkayu banyak berada pada penanaman tepi jalan. Jenis pohon berkayu antara lain beringin (Ficus benjamina), sengon (Paraserianthes falcataria), dan ki hujan (Samanea saman). Pohon berbunga banyak ditanam pada bagian median. Pohon berbunga memberi nilai keindahan pada jalur hijau jalan utama ini. Jenis pohon berbunga yang ada pada jalur hijau jalan MH Thamrin yaitu dadap merah (Erythrina christagalli) dan bunga kupu-kupu (Bauhinia blakeana). Jenis palem-paleman banyak digunakan pada jalur hijau jalan ini. Tanaman palem memiliki ciri khas dan bentuk yang 
menarik sehingga banyak ditanam pada lanskap jalan ini. Jenis palem yang ada di jalur hijau jalan ini yaitu palem Bismarck (Bismarckia nobilis), palem kuning (Chrisalidocarpus lutescens), kelapa sawit (Elaeis gueenensis), kelapa (Cocos nucifera), dan palem phoenix (Phoenix roebelenii).

Jenis pohon yang mendominasi pada jalur hijau jalan ini yaitu pinus (Pinus merkusii) dan cemara Norfolk (Araucaria heterophylla). Kedua jenis pohon ini banyak ditanam pada tepi jalan. Jenis lain yang cukup banyak terdapat pada jalur hijau jalan ini antara lain akasia (Acacia mangium), palem Bismarck (Bismarckia nobilis), kelapa (Cocos nucifera), dan kelapa sawit (Elaeis guineensis). Pohon akasia (Acacia mangium) banyak terdapat pada tepi jalan. Pohon ini merupakan tanaman penghijauan pada tapak dan juga salah satu tanaman perintis pada jalur hijau jalan ini sehingga jumlahnya memang cukup banyak. Selain pohon akasia (Acacia mangium), pohon kelapa (Cocos nucifera) juga banyak ditanam pada tepi jalan. Palem Bismarck (Bismarckia nobilis) dan kelapa sawit (Elaeis guineensis) banyak ditanam baik pada tepi maupun median jalan.

Vegetasi pada jalur hijau jalan $\mathrm{MH}$ Thamrin ditanam pada saat pelaksanaan konstruksi jalan. Berdasarkan hasil wawancara dengan pengelola, vegetasi perintis pada jalur hijau jalan ini antara lain akasia (Acacia mangium) dan sengon (Paraserianthes falcataria). Kedua jenis pohon ini banyak ditanam pada sisi jalan yang cukup jauh dari jalur kendaraan. Letak penanaman akasia dan sengon yang demikian dikarenakan sifat dahan pohon yang mudah patah. Jenisjenis pohon jalur hijau jalan dapat dilihat pada tabel berikut. 
Tabel 8 Pohon jalan MH Thamrin

\begin{tabular}{|c|c|c|c|c|}
\hline No. & Nama latin & Nama lokal & Family & Jumlah \\
\hline 1. & Acacia mangium & Akasia mangium & Fabaceae & 162 \\
\hline 2. & Araucaria heterophylla & Cemara norflok & Araucariaceae & 197 \\
\hline 3. & Bauhinia blakeana & Bunga kupu-kupu & Fabaceae & 33 \\
\hline 4. & Bismarckia nobilis & Palem bismarck & Arecaceae & 154 \\
\hline 5. & Bucida molineti & Ketapang & Combretaceae & 4 \\
\hline 6. & Chrysalidocarpus lutescens & Palem kuning & Arecaceae & 91 \\
\hline 7. & Cocos nucifera & Kelapa & Arecaceae & 102 \\
\hline 8. & Cordyline australis & Pandan bali & Laxmanniaceae & 3 \\
\hline 9. & Dillenia philipinensis & Sempur & Dilleniaceae & 1 \\
\hline 10. & Elaeis guineensis & Kelapa sawit & Arecaceae & 141 \\
\hline 11. & Erythrina cristagalli & Dadap merah & Papilionaceae & 92 \\
\hline 12. & Ficus benjamina & Beringin & Moraceae & 20 \\
\hline 13. & Ficus lyrata & Biola cantik & Moraceae & 2 \\
\hline 14. & Ficus sp. & Beringin & Moraceae & 13 \\
\hline 15. & Filicium decipiens & Kerai payung & Sapindaceae & 1 \\
\hline 16. & Gmelina arborea & Jati putih & Verbenaceae & 42 \\
\hline 17. & Livistona rotundifolia & Palem sadeng & Arecaceae & 83 \\
\hline 18. & Pandanus sp & Pandan hijau & Pandanaceae & 2 \\
\hline 19. & Pandanus utilis & Pandan melintir & Pandanaceae & 4 \\
\hline 20. & Paraserianthes falcataria & Sengon & Mimosaceae & 29 \\
\hline 21. & Phoenix roebelenii & Phoenix & Areaceae & 72 \\
\hline 22. & Pinus merkusii & Pinus & Pinaceae & 463 \\
\hline 23. & Plumeria rubra & Kamboja & Apocynaceae & 70 \\
\hline 24. & Ravenala madagascariensis & Pisang kipas & Strelitziaceae & 2 \\
\hline 25. & Roystonea regia & Palem raja & Arecaceae & 12 \\
\hline 26. & Salix babylonica & Salix/liang liu & Salicaceae & 6 \\
\hline 27. & Samanea saman & Ki hujan & Fabaceae & 48 \\
\hline 28. & Schefflera actinophylla & Walisongo & Araliaceae & 1 \\
\hline 29. & Spatodhea campanulata & Kecrutan & Bignoniaceae & 2 \\
\hline 30. & Tectona grandis & Jati & Verbenaceae & 5 \\
\hline 31. & Veitchia merilii & Palem putrid & Arecaceae & 24 \\
\hline 32. & Wodyetia bifurcate & Palem ekor tupai & Arecaceae & 8 \\
\hline Total & & & & 1889 \\
\hline
\end{tabular}


Seperti telah disebutkan sebelumnya, vegetasi yang mendominasi pada jalur hijau jalan ini antara lain pinus (Pinus merkusii) dan cemara Norfolk (Araucaria heterophylla). Kedua pohon ini termasuk jenis vegetasi konifer, yang merupakan tanaman dataran tinggi dan banyak terdapat pada kawasan pegunungan. Pemilihan pohon pinus (Pinus merkusii) dan cemara Norfolk (Araucaria heterophylla) terutama untuk menciptakan suasana pegunungan pada jalan, sesuai dengan konsep kawasan sebagai kota pegunungan. Selain itu, pinus (Pinus merkusii) dan cemara Norfolk (Araucaria heterophylla) termasuk jenis tanaman penghijauan pada jalur hijau jalan ini sehingga jumlahnya banyak. Pohon pinus (Pinus merkusii) dan cemara Norfolk (Araucaria heterophylla) terutama ditanam pada bagian tepi jalan.

Selain pohon-pohon tersebut, pohon yang jumlahnya cukup banyak pada lanskap jalan antara lain bunga kupu-kupu (Bauhinia blakeana), palem kuning (Chrysalidocarpus lutescens), dadap merah (Erythrina cristagalli), beringin (Ficus benjamina), jati putih (Gmelina arborea), palem sadeng (Livistona rotundifolia), sengon (Paraserianthes falcataria), palem phoenix (Phoenix roebelenii), kamboja (Plumeria rubra), ki hujan (Samanea saman), dan palem putri (Veitchia merilii). Pohon yang jumlahnya sedikit yaitu ketapang kencana (Bucida molineti), pandan bali (Cordyline australis), sempur (Dillenia philipinensis), biola cantik (Ficus lyrata), beringin (Ficus sp.), kerai payung (Filicium decipiens), pandan hijau (Pandanus sp), pandan melintir (Pandanus utilis), pisang kipas (Ravenala madagascariensis), palem raja (Roystonea regia), liang liu (Salix babylonica), walisongo (Schefflera actinophylla), kecrutan (Spatodhea campanulata), jati (Tectona grandis), dan palem ekor tupai (Wodyetia bifurcata).

Pohon sebagai elemen RTH memiliki berbagai nilai ekologis bagi kualitas lingkungan kota. Jalur hijau jalan merupakan salah satu bentuk RTH pada kota dengan elemen utama yaitu pohon jalan. Pohon jalan memiliki peran antara lain mengurangi pencemaran udara, produsen oksigen, peneduh dan penurun suhu. Vegetasi dapat mengurangi polutan yang lepas ke lingkungan karena vegetasi dapat menyerap berbagai jenis polutan seperti $\mathrm{CO}_{2}, \mathrm{CO}, \mathrm{NO}, \mathrm{NO}_{2}$, dan $\mathrm{SO}_{2}$. 
RTH memiliki berbagai fungsi ekologis, namun yang menjadi fokus penelitian ini yaitu fungsi RTH untuk menyerap polusi udara serta menjerap partikel. Untuk dapat mereduksi polusi dengan baik, diperlukan tanaman yang tahan terhadap polusi dan memiliki kemampuan untuk mereduksi gas pencemar. Ketahanan terhadap polusi dapat diketahui antara lain melalui nilai APTI (Air Pollution Tollerance Index), yaitu suatu angka yang menunjukkan tingkat toleransi tanaman terhadap polusi udara (Udayana, 2004). Berdasarkan studi pustaka, diketahui bahwa pada jenis-jenis pohon jalur hijau jalan tersebut, beberapa diantaranya diketahui memiliki toleransi terhadap polusi udara.

Diantara jenis-jenis pohon pada jalur hijau jalan MH Thamrin, pohon yang toleran terhadap polusi antara lain dadap merah (Erythrina cristagalli) dan ki hujan (Samanea saman). Tanaman dengan tingkat toleransi sedang terhadap polusi udara antara lain akasia mangium (Acacia mangium), cemara Norfolk (Araucaria heterophylla), daun kupu-kupu (Bauhinia blakeana), dan beringin (Ficus benjamina). Sementara itu, jati (Tectona grandis) dan sengon (Paraserianthes falcataria) temasuk jenis pohon yang sensitif terhadap polusi.

Tabel 9 Tingkat toleransi pohon jalan MH Thamrin

\begin{tabular}{lllll}
\hline No & Nama lokal & Nama latin & Nilai APTI * & Tingkat toleransi \\
\hline 1 & Akasia & Acacia mangium & 15 & Sedang \\
\hline 2 & Cemara Norfolk & Araucaria heterophylla & 13 & Sedang \\
\hline 3 & Daun kupu-kupu & Bauhinia blakeana & 16 & Sedang \\
\hline 4 & Dadap merah & Erythrina cristagalli & 21 & Toleran \\
\hline 5 & Beringin & Ficus benjamina & 16 & Sedang \\
\hline 6 & Sengon & Paraserianthes falcataria & 12 & Sensitif \\
\hline 7 & Ki hujan & Samanea saman & 24 & Toleran \\
\hline 8 & Jati & Tectona grandis & 6 & Sensitif \\
\hline
\end{tabular}

Keterangan : * sumber Singh et.al dalam Ernawati (2003) dan Udayana(2004)

Keefektifan fungsi RTH untuk mereduksi polusi udara selain dipengaruhi ketahanan tanaman terhadap pencemar juga dipengaruhi kemampuan tanaman dalam mereduksi zat pencemar. Kemampuan tanaman dalam mereduksi zat pencemar dapat diketahui dengan melihat jumlah serapan tanaman terhadap zat pencemar tersebut. 
Jenis-jenis tanaman tertentu dapat menyerap gas ${ }^{15} \mathrm{~N}$ dengan baik. Tingkat serapan gas ${ }^{15} \mathrm{~N}$ ini merefleksikan kemampuan tanaman dalam menyerap polutan $\mathrm{NO}_{2}$. Polutan $\mathrm{NO}_{2}$ adalah salah satu bentuk oksida nitrogen dan zat pencemar udara yang dihasilkan pada pembakaran bahan kendaraan bermotor. Polutan ini dapat mengakibatkan kerusakan pada tanaman dan sangat berbahaya bagi manusia (Fardiaz, 1992). Tingkat serapan ${ }^{15} \mathrm{~N}$ pada tanaman digunakan sebagai indikator kemampuan tanaman dalam menyerap polutan gas $\mathrm{NO}_{2}$ dari udara. Beberapa jenis pohon yang ada pada jalur hijau jalan $\mathrm{MH}$ Thamrin diketahui memiliki kemampuan dalam menyerap gas ${ }^{15} \mathrm{~N}$.

Diantara pohon-pohon pada jalur hijau jalan MH Thamrin yang diketahui memiliki kemampuan menyerap gas ${ }^{15} \mathrm{~N}$ yaitu ki hujan (Samanea saman), palem kuning (Chrysalidocarpus lutescens), kelapa sawit (Elaeis guinensis), walisongo (Schefflera actinophylla), kecrutan (Spatodhea campanulata) dan palem putri (Veitchia merilii). Selain pohon-pohon tersebut, akasia (Acacia mangium), cemara Norfolk (Araucaria heterophylla), kelapa (Cocos nucifera), sempur (Dillenia philipinensis), beringin (Ficus benjamina), kerai payung (Filicium decipiens), palem sadeng (Livistona rotundifolia) dan palem raja (Roystonea regia) juga disebutkan mampu menyerap gas ${ }^{15} \mathrm{~N}$. Jumlah serapan dari tanaman-tanaman tersebut dapat dilihat pada tabel berikut.

Tabel 10 Tingkat serapan ${ }^{15} \mathrm{~N}$ beberapa pohon jalan $\mathrm{MH}$ Thamrin

\begin{tabular}{cllc}
\hline No & \multicolumn{1}{c}{ Nama local } & \multicolumn{1}{c}{ Nama latin } & Serapan ${ }^{15} \mathrm{~N}($ dalam $\mu \mathrm{g} / \mathrm{g})$ \\
\hline 1 & Acacia mangium & Akasia & 0.28 \\
\hline 2 & Araucaria heterophylla & Cemara norflok & 4.76 \\
\hline 3 & Chrysalidocarpus lutescens & Palem kuning & 19.48 \\
\hline 4 & Cocos nucifera & Kelapa & 14.48 \\
\hline 5 & Dillenia philipinensis & Sempur & 11.03 \\
\hline 6 & Elaeis guinensis & Kelapa sawit & 17.81 \\
\hline 7 & Ficus benjamina & Beringin & 9.63 \\
\hline 8 & Filicium decipiens & Kerai payung & 3.46 \\
\hline 9 & Livistona rotundifolia & Palem sadeng & 10.6 \\
\hline 10 & Roystonea regia & Palem raja & 11.74 \\
\hline 11 & Samanea saman & Saman & 35.37 \\
\hline 12 & Schefflera actinophylla & Walisongo & 16.87 \\
\hline 13 & Spatodhea campanulata & Kecrutan & 26.88 \\
\hline 14 & Veitchia merilii & Palem putri & 18.66 \\
\hline
\end{tabular}

Sumber : Nasrullah et.al (2001) 
Jumlah serapan gas ${ }^{15} \mathrm{~N}$ dari jenis pohon-pohon tersebut berbeda-beda. Perbedaan jumlah serapan menandakan perbedaan kemampuan antara tiap jenis pohon untuk menyerap polutan $\mathrm{NO}_{2}$. Semakin tinggi nilai serapan, kemampuan jenis pohon tersebut untuk mereduksi polutan $\mathrm{NO}_{2}$ semakin baik.

Pohon juga diketahui efektif dalam menyerap karbondioksida dan menghasilkan oksigen. Beberapa jenis pohon pada jalur hijau jalan MH Thamrin diketahui memiliki tingkat serapan karbon dioksida. Pohon-pohon tersebut antara lain ki hujan (Samanea saman), beringin (Ficus benjamina), dan kerai payung (Felicium decipiens). Selain itu, terdapat juga jati (Tectona grandis), akasia (Acacia mangium) dan dadap merah (Erythrina christagalli). Besar serapan jenisjenis pohon tersebut bervariasi. Perbedaan besar serapan untuk tiap jenis pohon menandakan perbedaan kemampuan menyerap karbondioksida.

Tabel 11 Tingkat serapan karbon dioksida $\left(\mathrm{CO}_{2}\right)$ pohon jalan $\mathrm{MH}$ Thamrin

\begin{tabular}{lllc}
\hline No. & \multicolumn{1}{c}{ Nama lokal } & \multicolumn{1}{c}{ Nama ilmiah } & $\begin{array}{c}\text { Daya serap } \mathrm{CO}_{2} \\
(\mathrm{~kg} / \text { pohon/thn })\end{array}$ \\
\hline 1 & Ki hujan & Samanea saman & $28.488,39$ \\
\hline 2 & Beringin & Ficus benjamina & 535,90 \\
\hline 3 & Kerai payung & Felicium decipiens & 404,83 \\
\hline 4 & Jati & Tectona grandis & 135,27 \\
\hline 5 & Akasia & Acacia mangium & 15,19 \\
\hline 6 & Dadap merah & Erythrina cristagalli & 4,55 \\
\hline \multicolumn{2}{l}{ Sumber $:$ Dahlan dalam Duryatmo, 2008 }
\end{tabular}

Kemampuan ruang terbuka hijau dalam membersihkan pencemaran udara juga dipengaruhi oleh kepadatan dan struktur vegetasi. Ruang terbuka hijau dengan beberapa lapisan tanaman seperti, semak, perdu, dan pohon, dapat mereduksi lebih efektif. Jalur hijau jalan MH Thamrin memiliki penanaman yang berlapis. Selain penanaman pohon, ruang terbuka hijau juga ditanami berbagai jenis perdu, semak, groundcover, rumput, tanaman merambat, dan tanaman air. Struktur jalur hijau jalan MH Thamrin ini memiliki potensi dalam membersihkan pencemaran udara.

Pohon-pohon jalan ditanam di tepi dan median jalan. Selain pohon, perdu, semak, groundcover, dan rumput juga ditanam pada jalur tepi dan median jalan serta pada pulau jalan. Tanaman merambat melilit pada elemen penunjang jalan 
seperti lampu jalan dan melilit pada berbagai jenis pohon. Tanaman air ditanam pada pot dan diletakkan di tepi dan median jalan. Keragaman jenis pohon dan tanaman lain pada lanskap jalan ini cukup banyak dan bervariasi. Jenis tanaman yang beragam memberi nilai estetika yang lebih pada lanskap jalan MH Thamrin.

Berdasarkan hasil identifikasi vegetasi, tanaman pada jalur hijau jalan Sentul City cukup beragam, tidak hanya pohon, namun juga semak, perdu, dan tanaman-tanaman pendek lainnya. Pada jalur hijau jalan terdapat berbagai jenis pohon yaitu konifer, pohon berbunga, peneduh, dan berbagai jenis palem. Pohon jalan tersebut selain memberikan nilai estetika jalan juga mempunyai berbagai fungsi dalam mendukung lingkungannya. Keragaman jenis tanaman juga membentuk lapisan-lapisan vegetasi yang dapat mengefektifkan pembersihan pencemaran udara.

\subsection{Analisis Fungsi Ekologis Jalur Hijau Jalan}

Jalan merupakan sarana pada sistem transportasi dan dilalui oleh berbagai macam jenis alat transportasi. Kawasan perkotaan umumnya memiliki lalu lintas yang padat sehingga tingkat polusi kota lebih tinggi dibandingkan kawasan sekitarnya. Walaupun keadaan umum jalan kota seperti itu, saat ini kondisi pergerakan kendaraan pada kawasan Sentul City masih tergolong rendah (PT Sentul City Tbk., 2009). Namun terdapat potensi peningkatan jumlah kendaraan pada kawasan ini mengingat kawasan permukiman Sentul City belum sepenuhnya beroperasi. Kendaraan bermotor memiliki beberapa dampak negatif bagi lingkungan salah satunya timbulnya polusi udara. Pembakaran bahan bakar pada alat transportasi menjadi salah satu sumber utama pencemaran udara karena menghasilkan zat pencemar udara seperti gas timbal $(\mathrm{Pb})$, oksida karbon $\left(\mathrm{CO}_{\mathrm{x}}\right)$, oksida nitrogen $\left(\mathrm{NO}_{\mathrm{x}}\right)$, dan oksida sulfida $\left(\mathrm{SO}_{\mathrm{x}}\right)$ (Fandeli, 2009). Peningkatan jumlah kendaraan dapat menyebabkan peningkatan tingkat pencemaran udara. Tingginya tingkat pencemaran udara dapat mengurangi kenyamanan bagi para penghuni kawasan.

Lokasi penelitian yaitu jalan utama MH Thamrin dilengkapi jalur hijau jalan yang luas dan estetis. RTH, termasuk di dalamnya jalur hijau jalan, sendiri selain menambah nilai estetika bagi lingkungan, juga diketahui memiliki berbagai 
fungsi ekologis sebagai paru-paru kota, pengatur iklim mikro, peneduh, penyedia oksigen, penyerap air hujan, habitat satwa, penyerap polutan dan penahan angin. Fungsi ekologis yang dianalisis pada bagian ini yaitu fungsi ekologis jalur hijau jalan dalam menyerap polutan gas dan menjerap partikel.

\subsubsection{Penyerap polutan gas}

Pencemaran atau polusi udara merupakan peristiwa berubahnya komposisi udara dari keadaan normalnya akibat adanya bahan-bahan atau zat-zat asing di dalam udara. Penyebab polusi antara lain pembakaran, transportasi, proses industri dan pembuangan limbah. Diantara sumber-sumber polusi, transportasi dikatakan menjadi sumber polusi yang utama karena menghasilkan berbagai gas pencemar.

Ruang terbuka hijau dapat membantu mengurangi polusi udara. Zat-zat pencemar udara yang berbentuk gas, dikurangi konsentrasinya oleh tanaman melalui penyerapan. Beberapa jenis tanaman diketahui dapat menyerap jenis-jenis polutan tertentu dengan baik.

Berdasarkan PT Sentul City Tbk. (2009), pada kawasan Sentul City terdapat beberapa jenis pencemar udara yaitu, oksida nitrogen $\left(\mathrm{NO}_{\mathrm{x}}\right)$, sulfur dioksida $\left(\mathrm{SO}_{2}\right)$, karbon monoksida (CO), amoniak, hidrogen sulfida $\left(\mathrm{H}_{2} \mathrm{~S}\right)$, Oksidan $\left(\mathrm{O}_{3}\right)$. Dari jenis-jenis pencemar tersebut, oksida nitrogen $\left(\mathrm{NO}_{\mathrm{x}}\right)$, sulfur dioksida $\left(\mathrm{SO}_{2}\right)$ dan karbon monoksida (CO) merupakan jenis zat yang dihasilkan dari pembakaran bahan bakar kendaraan bermotor. Hal ini menunjukkan, transportasi dan kendaraan bermotor memiliki pengaruh pada kualitas udara kawasan.

Pengukuran terhadap zat-zat pencemar tersebut dilakukan pada beberapa lokasi dalam kawasan. Lokasi-lokasi tersebut adalah meliputi akses tol depan mall/area komersial Bellanova, Jl MH Thamrin (U1), akses masuk Kp Pasir Maung/ke kantor kecamatan (U2), bagian depan Perumahan Mediterania (U3) dan akses Kp Banceuy (U4) menunjukkan tingkat pencemaran yang bervariasi (Pekerjaan pemantauan RKL/RPL Pembangunan Kawasan Perumahan Sentul City, 2009). Dari hasil pengukuran, diketahui jumlah-jumlah zat pencemar dalam 
kawasan. Jumlah zat pencemar bervariasi pada tiap lokasi, namun secara umum tingkat pencemar belum melampaui baku mutu udara ambient.

Tabel 12 Jumlah gas pencemar pada tahun 2009

\begin{tabular}{|c|c|c|c|c|c|c|c|}
\hline \multirow[b]{2}{*}{ No } & \multirow[b]{2}{*}{ Parameter } & \multirow[b]{2}{*}{ Satuan } & \multicolumn{4}{|c|}{ Lokasi } & \multirow[b]{2}{*}{ Baku mutu } \\
\hline & & & U1 & U2 & U3 & U4 & \\
\hline 1 & $\mathrm{NO}_{2}$ & $\mu \mathrm{g} / \mathrm{Nm}^{3}$ & 5.8 & 5.92 & 5.54 & 5.5 & 400 \\
\hline 2 & $\mathrm{SO}_{2}$ & $\mu g / \mathrm{Nm}^{3}$ & 110.19 & 119.49 & 131.01 & 108.18 & 900 \\
\hline 3 & $\mathrm{CO}$ & $\mu \mathrm{g} / \mathrm{Nm}^{3}$ & 145.7 & 140.4 & 140.4 & 227.4 & 30000 \\
\hline 4 & $\mathrm{O}_{3}$ & $\mu \mathrm{g} / \mathrm{Nm}^{3}$ & 1.98 & 2.04 & 0.76 & 0.55 & 235 \\
\hline 5 & $\mathrm{H}_{2} \mathrm{~S}$ & ppm & $<0.005$ & $<0.005$ & $<0.005$ & $<0.005$ & 0.02 \\
\hline 6 & $\mathrm{NH}_{3}$ & ppm & $<0.1$ & 0.01 & $<0.01$ & $<0.01$ & 2 \\
\hline
\end{tabular}

Sumber : PT Sentul City Tbk (2009)

Baku mutu kualitas udara ambient untuk $\mathrm{NO}_{2}, \mathrm{SO}_{2}$, $\mathrm{CO}$, dan $\mathrm{O}_{3}$ berdasarkan Peraturan Pemerintah Republik Indonesia No 41 Tahun 1999

Baku mutu kualitas udara ambient untuk $\mathrm{H}_{2} \mathrm{~S}$ dan $\mathrm{NH}_{3}$ berdasarkan Keputusan Menteri lingkungan hidup KEP-50/MENLH/11/1996

Keterangan lokasi

U1 : akses tol depan mall/area komersial Bellanova, Jl MH Thamrin

U2 : akses masuk Kp Pasir Maung/ke kantor kecamatan

U3 : bagian depan Perumahan Mediterania

U4 : akses Kp Banceuy

Jumlah pencemar nitrogen dioksida $\left(\mathrm{NO}_{2}\right)$ pada kawasan Sentul City cenderung pada tingkatan yang hampir sama yaitu antara $5.5-5.92 \mu \mathrm{g} / \mathrm{Nm}^{3}$. Jumlah tersebut masih sangat kecil dan masih jauh dari ambang batas untuk nitrogen dioksida yaitu sebesar $400 \mu \mathrm{g} / \mathrm{Nm}^{3}$. Zat pencemar sulfur dioksida $\left(\mathrm{SO}_{2}\right)$ pada kawasan Sentul City berjumlah antara 108.18 - $131.01 \mu \mathrm{g} / \mathrm{Nm}^{3}$. Jumlah ini masih cukup jauh dari ambang batas yang sebesar $900 \mu \mathrm{g} / \mathrm{Nm}^{3}$. Tingkat pencemar karbon monoksida (CO) pada beberapa lokasi di Sentul City berada pada tingkat jumlah yang hampir sama yaitu 140,4 - 145, $7 \mu \mathrm{g} / \mathrm{Nm}^{3}$. Namun pada salah satu lokasi, jumlah karbon monoksida sangat tinggi yaitu 227,4 $\mu \mathrm{g} / \mathrm{Nm}^{3}$. Walaupun demikian, jumlah karbon monoksida ini masih rendah bila dibandingkan dengan ambang batas sejumlah $30000 \mu \mathrm{g} / \mathrm{Nm}^{3}$. 
Tingkat ozon $\left(\mathrm{O}_{3}\right)$ pada kawasan Sentul City berkisar antara 0,55 - 2,04 $\mu \mathrm{g} / \mathrm{Nm}^{3}$. Jumlah tersebut masih berada di bawah batas pencemaran ozon yang diperkenankan yaitu sejumlah $235 \mu \mathrm{g} / \mathrm{Nm}^{3}$. Jumlah asam sulfida $\left(\mathrm{H}_{2} \mathrm{~S}\right)$ di dalam kawasan ini < 0,005 ppm dan masih berada di bawah ambang batasnya yaitu 0,02 ppm. Tingkat ammonia (NH3) pada kawasan Sentul City berada pada kisaran jumlah $<0,01-0,1$ ppm. Jumlah tersebut masih berada di bawah baku mutu yaitu 2 ppm.

Baku mutu udara ambient merupakan ukuran batas atau kadar zat, energi, dan atau komponen yang ada atau seharusnya ada dan/atau unsur pencemaran yang ditenggang keberadaannya (PP RI No. 41 thn 1999). Tingkat zat pencemar yang ada dalam kawasan Sentul City belum melampaui baku mutu udara ambien. Karena itu, dapat dikatakan tingkat pencemaran yang ada di dalam kawasan Sentul City masih dapat ditoleransi atau belum cukup berbahaya bagi lingkungan sekitarnya.

Pada lokasi pengukuran yang terdekat dengan jalan $\mathrm{MH}$ Thamrin yaitu U1, jumlah zat-zat pencemar yang terdeteksi belum melampaui baku mutu udara ambient. Hal ini menandakan bahwa tingkat pencemaran gas yang dihasilkan oleh kendaraan-kendaraan pada jalan $\mathrm{MH}$ Thamrin belum pada tingkat yang berbahaya.

Jalur hijau jalan MH Thamrin luas dan estetis dengan penanaman banyak jenis pohon. Pohon-pohon jalan memiliki berbagai fungsi ekologis bagi lingkungan seperti penghasil oksigen dan pereduksi polusi. Dari berbagai jenis pohon pada jalur hijau jalan tersebut, beberapa diantaranya merupakan jenis pohon yang dapat menoleransi pencemaran udara. Pohon dadap merah (Erythrina cristagalli) dan ki hujan (Samanea saman) termasuk jenis pohon yang toleran (Udayana, 2004). Pohon ki hujan juga diketahui sebagai pohon penyerap karbondioksida yang sangat baik. Serapan karbondioksida pohon ini sangat besar dibandingkan jenis pohon lainnya. Kedua jenis pohon ini, yaitu dadap merah dan ki hujan, banyak terdapat pada tepi dan median jalan, dan jumlah kedua jenis pohon tersebut pada RTH cukup banyak.

Pohon lain pada jalur hijau jalan yang disebutkan toleran terhadap polusi udara yaitu akasia mangium (Acacia mangium), cemara Norfolk (Araucaria 
heterophylla), daun kupu-kupu (Bauhinia blakeana), dan beringin (Ficus benjamina). Pohon-pohon ini memiliki tingkat toleransi sedang terhadap polusi udara. Jumlah pohon-pohon tersebut pada jalur hijau jalan sudah cukup banyak. Jalur hijau jalan MH Thamrin telah memiliki jenis pohon yang toleran dan cukup dapat menoleransi polusi udara. Namun pohon jati (Tectona grandis) dan sengon (Paraserianthes falcataria) temasuk jenis pohon yang sensitif terhadap polusi udara.

Pohon dapat mereduksi pencemar antara lain melalui penyerapan polutanpolutan gas. Pohon diketahui dapat menyerap berbagai polutan dengan baik. Salah satu polutan yang dapat diserap oleh pohon yaitu gas ${ }^{15} \mathrm{~N}$. Jenis-jenis pohon tertentu dapat menyerap gas ${ }^{15} \mathrm{~N}$ dengan baik. Pada jalur hijau jalan $\mathrm{MH}$ Thamrin, terdapat pohon yang disebutkan dapat menyerap gas ${ }^{15} \mathrm{~N}$ dengan baik. Kemampuan menyerap gas ${ }^{15} \mathrm{~N}$ merupakan indikator kemampuan tanaman untuk menyerap polutan nitrogen dioksida $\left(\mathrm{NO}_{2}\right)$. Tingkat penyerapan yang tinggi oleh tanaman dapat mengurangi konsentrasi polutan gas ${ }^{15} \mathrm{~N}$ di udara.

Pohon ki hujan (Samanea saman) dapat menyerap gas ${ }^{15} \mathrm{~N}$ dengan baik. Pohon ini memiliki tingkat serapan yang tinggi yaitu lebih dari $30 \mu \mathrm{g} / \mathrm{g}$. Selain itu, palem kuning (Chrysalidocarpus lutescens), kelapa sawit (Elaeis guinensis), walisongo (Schefflera actinophylla), kecrutan (Spatodhea campanulata) dan palem putri (Veitchia merilii) juga dapat menyerap gas ${ }^{15} \mathrm{~N}$. Pohon-pohon tersebut memiliki tingkat serapan sedang yaitu antara $15 \mu \mathrm{g} / \mathrm{g}$ sampai $30 \mu \mathrm{g} / \mathrm{g}$. Jumlah pohon-pohon tersebut pada jalur hijau jalan MH Thamrin cukup banyak.

RTH yang memiliki beberapa lapisan tanaman lebih efektif untuk mereduksi polusi. RTH yang terdiri dari tanah, semak dan pohon dapat mereduksi polusi dengan lebih baik. Jalur hijau jalan MH Thamrin terdiri dari beberapa lapis tanaman. Lapisan pohon dikombinasikan dengan penanaman tanaman yang lebih rendah seperti jenis penutup tanah, semak, dan perdu. Penanaman tersebut membentuk lapisan vegetasi yang bervariasi.

Tingkat pencemaran pada kawasan belum melampaui baku mutu sehingga dapat dikatakan tingkat pencemaran pada saat ini masih rendah. Pencemaran tersebut masih dapat ditoleransi atau belum cukup berbahaya. Jumlah kendaraan yang beroperasi dalam kawasan relatif masih rendah karena kawasan belum 
sepenuhnya beroperasi. Pada jalur hijau jalan MH Thamrin sudah terdapat beberapa jenis tanaman yang dapat menyerap polutan, antara lain menyerap $\mathrm{NO}_{2}$ dan $\mathrm{CO}_{2}$.

\subsubsection{Penjerap partikel}

Partikel merupakan salah satu jenis pencemar udara dan termasuk dalam jenis polutan yang cukup mempengaruhi pencemaran udara. Partikel secara sempit diartikan sebagai partikel padat namun secara lebih luas dapat meliputi berbagai macam bentuk, mulai dari bentuk yang sederhana sampai kompleks (Wardhana, 2001). Partikel dapat terjadi karena faktor alam maupun aktivitas manusia. Pencemaran partikel umumnya bersumber pada transportasi, industri maupun pembuangan limbah.

Ruang terbuka hijau dapat berfungsi untuk mengurangi pencemaran udara. Tanaman mengurangi pencemaran udara melalui mekanisme penyerapan dan penjerapan. Untuk jenis pencemar partikel, tanaman mereduksi dengan menjerap partikel pada berbagai bagian permukaan tanaman.

Berdasarkan PT Sentul City Tbk. (2009), jenis partikel yang terdapat pada kawasan Sentul City yaitu debu dan timbal $(\mathrm{Pb})$. Timbal $(\mathrm{Pb})$ dan debu termasuk jenis zat yang dihasilkan dari pembakaran bahan bakar kendaraan bermotor. Hal ini menunjukkan, transportasi dalam kawasan dan penggunaan kendaraan bermotor mempengaruhi kualitas udara kawasan.

Pengukuran tingkat partikel dilakukan pada beberapa lokasi dalam kawasan. Lokasi-lokasi pengukuran meliputi akses tol depan mall/area komersial Bellanova, Jl MH Thamrin (U1), akses masuk Kp Pasir Maung/ke kantor kecamatan (U2), bagian depan Perumahan Mediterania (U3) dan akses Kp Banceuy (U4) menunjukkan tingkat pencemaran yang bervariasi (Pekerjaan pemantauan RKL/RPL Pembangunan Kawasan Perumahan Sentul City, 2009). Dari hasil pengukuran diketahui bahwa pada lokasi-lokasi pengukuran tersebut diketahui terdapat sejumah partikel debu dan timbal. 
Tabel 13 Tingkat pencemaran partikel tahun 2009

\begin{tabular}{|c|c|c|c|c|c|c|c|}
\hline \multirow[b]{2}{*}{ No } & \multirow[b]{2}{*}{ Parameter } & \multirow[b]{2}{*}{ Satuan } & \multicolumn{4}{|c|}{ Lokasi } & \multirow[b]{2}{*}{ Baku Mutu } \\
\hline & & & U1 & $\mathrm{U} 2$ & U3 & U4 & \\
\hline 1 & $\mathrm{~Pb}$ & $\mu \mathrm{g} / \mathrm{Nm}^{3}$ & 0.05 & 0.05 & 0.05 & 0.1 & 2 \\
\hline 2 & Debu & $\mu g / \mathrm{Nm}^{3}$ & 19.75 & 20.16 & 32.49 & 35.48 & 230 \\
\hline \multicolumn{8}{|c|}{ Sumber : PT Sentul City Tbk. (2009) } \\
\hline \multicolumn{8}{|c|}{$\begin{array}{l}\text { Baku mutu kualitas udara amb } \\
\text { Indonesia No } 41 \text { Tahun } 1999\end{array}$} \\
\hline \multicolumn{8}{|c|}{ Keterangan lokasi } \\
\hline \multicolumn{8}{|c|}{ U1 : akses tol depan mall/area komersial Bellanova, Jl MH Thamrin } \\
\hline \multicolumn{8}{|c|}{ U2 : akses masuk Kp Pasir Maung/ke kantor kecamatan } \\
\hline \multicolumn{8}{|c|}{ U3 : bagian depan Perumahan Mediterania } \\
\hline U4 : & ses Kp Bar & & & & & & \\
\hline
\end{tabular}

Jumlah timbal pada beberapa lokasi yaitu Jl MH Thamrin, akses masuk Kp Pasir Maung/ke kantor kecamatan dan Perumahan Mediterania relatif sama, yaitu $0,05 \mu \mathrm{g} / \mathrm{Nm}^{3}$. Sementara itu pada akses Kampung Banceuy, tingkat pencemaran timbal 0,1 $\mu \mathrm{g} / \mathrm{Nm}^{3}$ dan merupakan jumlah tertinggi. Walaupun demikian, jumlah pencemaran timbal pada kawasan Sentul City belum melampaui baku mutu udara ambient untuk timbal yaitu sebesar $2 \mu \mathrm{g} / \mathrm{Nm}^{3}$.

Selain timbal, jenis partikel pencemar lain yang ada dalam kawasan ini adalah debu. Tingkat pencemaran debu pada tiap lokasi berbeda-beda. Pencemaran debu terendah, yaitu sejumlah $19,75 \mu \mathrm{g} / \mathrm{Nm}^{3}$, terdapat pada jalan $\mathrm{MH}$ Thamrin yang berdekatan dengan tol Jagorawi. Tingkat pencemaran debu tertinggi pada lokasi akses kampung Banceuy yaitu 35,48 $\mu \mathrm{g} / \mathrm{Nm}^{3}$. Tingkat pencemaran debu yang terukur pada beberapa lokasi di Sentul City belum melampaui baku mutu untuk pencemaran debu yaitu $230 \mu \mathrm{g} / \mathrm{Nm}^{3}$.

Jumlah timbal yang terukur pada kawasan Sentul City masih rendah. Tingkat pencemaran timbal pada kawasan ini belum melampaui baku mutu jumlah timbal udara. Jumlah debu pada kawasan juga masih rendah. Tingkat pencemaran debu pada kawasan ini belum melampaui baku mutu untuk jumlah debu yang diperbolehkan. Sementara itu, pada lokasi pengukuran yang terdekat dengan jalan lokasi penelitian yaitu U1, jumlah partikel yang terdeteksi belum melampaui baku mutu udara ambient. Hal ini menandakan bahwa tingkat pencemaran partikel pada jalan MH Thamrin belum pada tingkat yang berbahaya. 
Partikel dapat direduksi oleh tanaman melalui proses penjerapan oleh permukaan tanaman. Permukaan tanaman baik permukaan daun maupun batang tanaman dapat menjerap partikel. Untuk penjerapan, jenis tanaman yang baik yaitu jenis yang memiliki permukaan yang kasar. Permukaan yang kasar dapat berupa permukaan daun maupun permukaan ranting dan batang.

Jenis pohon konifer, seperti pinus (Pinus merkusii) dan cemara kipas (Thuja orientalis), sangat baik dalam menjerap partikel (Taihuttu, 2001). Pinus (Pinus merkusii) merupakan salah satu jenis tanaman utama pada RTH jalan MH Thamrin dan jumlahnya pada RTH jalan banyak. Jenis pohon dengan daun besar dan memiliki permukaan daun kasar dan berbulu baik dalam menjerap partikel. Pohon pada lanskap jalan yang memiliki ciri daun seperti ini antara lain jati (Tectona grandis) dan jati putih (Gmelina arborea). Pohon dengan daun kecil dan kasar cukup baik dalam menjerap partikel. Salah satu contoh jenis pohon pada lanskap jalan $\mathrm{MH}$ Thamrin yang memiliki ciri daun tersebut yaitu ki hujan (Samanea saman).

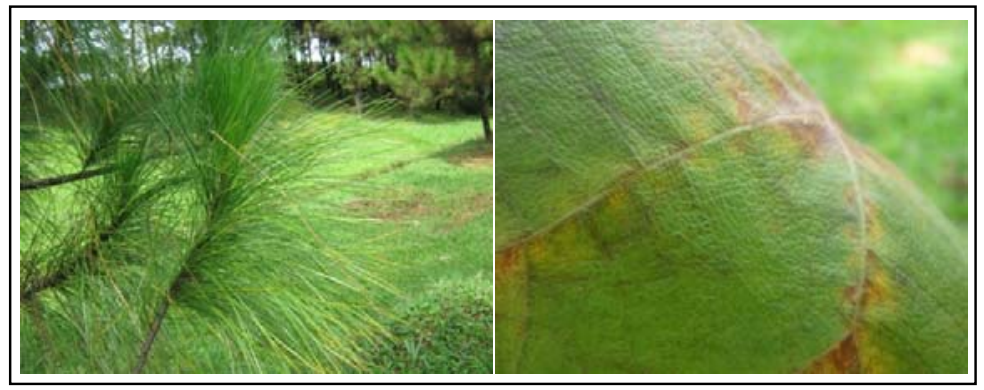

Gambar 25 Karakteristik daun untuk menjerap partikel

RTH yang terdiri dari beberapa lapisan tanaman, lapisan tanah, semak, pohon disebutkan lebih efektif dalam menjerap partikel. Lapisan tanaman memiliki permukaan penjerapan yang lebih besar dan juga membentuk struktur yang lebih rapat. Jalur hijau jalan $\mathrm{MH}$ Thamrin terdiri dari beberapa lapis tanaman. Lapisan pohon yang ada pada jalur hijau jalan dikombinasikan dengan penanaman tanaman dengan tinggi yang lebih rendah sehingga terbentuk lapisan vegetasi dengan ketinggian yang bervariasi.

Tingkat pencemaran partikel pada kawasan belum melampaui baku mutu kualitas udara ambient. Hal ini dapat disebabkan jumlah kendaraan yang 
beroperasi dalam kawasan relatif masih sedikit. Dengan demikian, tingkat pencemaran partikel pada saat ini masih dalam tingkat yang bisa ditoleransi dan belum cukup berbahaya. Pada jalur hijau jalan sudah terdapat jenis-jenis tanaman yang baik untuk menjerap partikel.

\subsection{Penilaian Fungsi Ekologis Jalur Hijau Jalan}

Tingkat pencemaran pada jalan relatif tinggi terkait dengan penggunaan kendaraan bermotor pada sistem transportasi kota. Ruang terbuka hijau memiliki berbagai fungsi, salah satu fungsi yang penting yaitu untuk mengurangi pencemaran udara. Karena itu, dilakukan penilaian untuk mengetahui fungsi ekologis jalur hijau jalan dalam mengurangi polusi udara. Jalur hijau jalan merupakan bentuk RTH pada jalan MH Thamrin.

Penilaian pada penelitian ini dilakukan pada tiap spesies tanaman karena tiap spesies tanaman memiliki karakter yang berbeda dengan spesies lainnya. Nilai diberikan berdasarkan kesesuaian ciri fisik dan kondisi lapang pohon dengan kriteria penilaian yang dipilih. Pohon dipilih sebagai objek evaluasi karena pohon memiliki efek penyerapan dan penjerapan terhadap zat pencemar yang lebih baik di antara elemen tanaman lainnya.

\subsubsection{Evaluasi Fungsi Ekologis Penyerap Polutan Gas}

Pohon mereduksi polusi melalui penyerapan gas pencemar. Penilaian vegetasi jalur hijau jalan untuk fungsi penyerap polutan gas dilakukan pada pohon tepi jalan, median, dan traffic islands. Penilaian dilakukan dengan membandingkan kondisi pohon pada lokasi penelitian dengan kriteria-kriteria vegetasi yang efektif dalam mereduksi polusi yang dirangkum dari berbagai literatur terkait. Kriteria yang dipilih untuk penilaian terutama yang dapat diamati secara langsung.

Untuk menyerap polusi dengan baik, diperlukan luas permukaan vegetasi yang cukup tinggi. Vegetasi dengan ketinggian elemen tanaman yang bervariasi dapat menghalangi menyebarnya polutan. Kombinasi pohon dengan perdu, semak, dan groundcover memiliki luas permukaan yang lebih tinggi dan dapat menghalangi dan memperlambat penyebaran polutan. Selain itu, untuk 
mendapatkan hasil reduksi yang maksimal, diperlukan tanaman penyangga dengan ketebalan yang cukup. Penanaman beberapa lapis pohon akan lebih efektif dalam mereduksi polusi.

Daun berperan penting dalam menyerap polutan udara. Jumlah daun pada suatu pohon dapat mempengaruhi penyerapan zat pencemar. Pohon dengan jumlah daun yang banyak lebih baik dalam penyerapan zat pencemar sehingga dapat mereduksi polusi dengan lebih baik. Ketebalan daun mempengaruhi penyerapan gas. Daun yang tebal memiliki jaringan yang tebal sehingga sulit ditembus. Daun yang tipis akan lebih mudah menyerap gas dan lebih baik untuk mereduksi zat pencemar udara.

Kepadatan tajuk pohon mempengaruhi keefektifan penyaringan zat pencemar udara. Tajuk yang rapat dan padat dapat menyerap polusi lebih baik dibanding tajuk yang terbuka. Jarak tanam yang rapat baik untuk fungsi mereduksi polusi. Pohon yang ditanam rapat akan menjadi penghalang untuk penyebaran zat pencemar udara.

Dari hasil penilaian, dapat diketahui jenis-jenis vegetasi pada jalur hijau jalan yang sesuai, cukup sesuai, ataupun tidak sesuai untuk fungsi menyerap polutan gas. Tanaman yang sangat sesuai untuk menyerap polutan gas, dari hasil penilaian, antara lain Acacia mangium, Araucaria heterophylla, Pinus merkusii, Samanea saman, dan Ficus benjamina. Tanaman yang sangat sesuai untuk menyerap polutan gas ini memiliki ciri fisik dan kondisi lapang yang sesuai dengan kriteria. Kelima jenis ini memenuhi hampir semua standar penilaian. Akasia mangium, cemara Norfolk, dan pinus merupakan jenis-jenis tanaman utama pada jalur hijau jalan ini dan ditanam dalam jumlah banyak dengan beberapa lapis tanaman. Selain itu, kelima jenis ini juga memiliki karakter fisik yang menunjang untuk menyerap polutan gas seperti tajuk yang massif, daun dalam jumlah banyak dan tipis hingga ketebalan sedang, dan ditanam dalam jarak yang cukup rapat. Selain itu, penanaman juga dikombinasikan dengan perdu, semak, dan groundcover. 
Tabel 14 Evaluasi fungsi penyerap polutan gas

\begin{tabular}{|c|c|c|c|c|c|c|c|c|c|c|c|}
\hline No & Nama latin & Nama lokal & $\begin{array}{c}\mathrm{K} \\
1 \\
\end{array}$ & $\begin{array}{l}K \\
2 \\
\end{array}$ & $\begin{array}{l}K \\
3 \\
\end{array}$ & $\begin{array}{l}\mathrm{K} \\
4 \\
\end{array}$ & $\begin{array}{l}K \\
5 \\
\end{array}$ & $\begin{array}{c}\text { Nilai } \\
\text { aktual }\end{array}$ & $\begin{array}{c}\text { Nilai } \\
\text { standar }\end{array}$ & $\begin{array}{c}\text { Nilai } \\
\text { evaluasi } \\
(\%)\end{array}$ & Kesesuaian \\
\hline 1 & Acacia mangium & $\begin{array}{l}\text { Akasia } \\
\text { mangium }\end{array}$ & 4 & 3 & 3 & 4 & 4 & 18 & 20 & 90 & Sangat sesuai \\
\hline 2 & $\begin{array}{l}\text { Araucaria } \\
\text { heterophylla }\end{array}$ & $\begin{array}{l}\text { Cemara } \\
\text { norflok }\end{array}$ & 3 & 4 & 2 & 4 & 4 & 17 & 20 & 85 & Sangat sesuai \\
\hline 3 & Bauhinia blakeana & $\begin{array}{l}\text { Bunga kupu- } \\
\text { kupu }\end{array}$ & 3 & 3 & 4 & 3 & 2 & 15 & 20 & 75 & Sesuai \\
\hline 4 & Bismarckia nobilis & $\begin{array}{l}\text { Palem } \\
\text { bismarck }\end{array}$ & 2 & 2 & 1 & 1 & 3 & 9 & 20 & 45 & $\begin{array}{l}\text { Kurang } \\
\text { sesuai }\end{array}$ \\
\hline 5 & Bucida molineti & Ketapang & 3 & 2 & 4 & 4 & 3 & 16 & 20 & 80 & Sesuai \\
\hline 6 & $\begin{array}{l}\text { Chrysalidocarpus } \\
\text { lutescens }\end{array}$ & Palem kuning & 1 & 3 & 4 & 2 & 2 & 12 & 20 & 60 & $\begin{array}{l}\begin{array}{l}\text { Kurang } \\
\text { sesuai }\end{array} \\
\end{array}$ \\
\hline 7 & Cocos nucifera & Kelapa & 2 & 2 & 3 & 3 & 2 & 12 & 20 & 60 & $\begin{array}{l}\text { Kurang } \\
\text { sesuai }\end{array}$ \\
\hline 8 & Cordyline australis & Pandan bali & 1 & 1 & 2 & 1 & 1 & 6 & 20 & 30 & Tidak sesuai \\
\hline 9 & $\begin{array}{l}\text { Dillenia } \\
\text { philipinensis }\end{array}$ & Sempur & 4 & 1 & 3 & 4 & 1 & 13 & 20 & 65 & Sesuai \\
\hline 10 & Elaeis guineensis & Kelapa sawit & 3 & 3 & 3 & 4 & 3 & 16 & 20 & 80 & Sesuai \\
\hline 11 & Erythrina cristagalli & Dadap merah & 3 & 3 & 3 & 3 & 2 & 14 & 20 & 70 & Sesuai \\
\hline 12 & Ficus benjamina & Beringin & 4 & 2 & 3 & 4 & 4 & 17 & 20 & 85 & Sangat sesuai \\
\hline 13 & Ficus lyrata & Biola cantik & 4 & 1 & 3 & 4 & 1 & 13 & 20 & 65 & Sesuai \\
\hline 14 & Ficus sp. & Beringin & 4 & 1 & 2 & 4 & 3 & 14 & 20 & 70 & Sesuai \\
\hline 15 & Filicium decipiens & Kerai payung & 4 & 1 & 4 & 4 & 1 & 14 & 20 & 70 & Sesuai \\
\hline 16 & Gmelina arborea & Jati putih & 2 & 2 & 3 & 2 & 3 & 12 & 20 & 60 & $\begin{array}{l}\text { Kurang } \\
\text { sesuai }\end{array}$ \\
\hline 17 & $\begin{array}{l}\text { Livistona } \\
\text { rotundifolia }\end{array}$ & Palem sadeng & 1 & 2 & 3 & 1 & 2 & 9 & 20 & 45 & $\begin{array}{l}\text { Kurang } \\
\text { sesuai }\end{array}$ \\
\hline 18 & Pandanus $s p$ & Pandan hijau & 4 & 1 & 1 & 2 & 1 & 9 & 20 & 45 & $\begin{array}{l}\text { Kurang } \\
\text { sesuai }\end{array}$ \\
\hline 19 & Pandanus utilis & $\begin{array}{l}\text { Pandan } \\
\text { melintir }\end{array}$ & 1 & 2 & 1 & 2 & 1 & 7 & 20 & 35 & Tidak sesuai \\
\hline 20 & $\begin{array}{l}\text { Paraserianthes } \\
\text { falcataria }\end{array}$ & Sengon & 3 & 1 & 4 & 4 & 1 & 13 & 20 & 65 & Sesuai \\
\hline 21 & Phoenix roebelenii & Phoenix & 2 & 2 & 3 & 3 & 2 & 12 & 20 & 60 & $\begin{array}{l}\text { Kurang } \\
\text { sesuai }\end{array}$ \\
\hline 22 & Pinus merkusii & Pinus & 3 & 4 & 3 & 4 & 4 & 18 & 20 & 90 & Sangat sesuai \\
\hline 23 & Plumeria rubra & Kamboja & 1 & 3 & 3 & 2 & 2 & 11 & 20 & 55 & $\begin{array}{l}\text { Kurang } \\
\text { sesuai }\end{array}$ \\
\hline 24 & $\begin{array}{l}\text { Ravenala } \\
\text { madagascariensis }\end{array}$ & Pisang kipas & 1 & 2 & 3 & 1 & 2 & 9 & 20 & 45 & $\begin{array}{l}\text { Kurang } \\
\text { sesuai }\end{array}$ \\
\hline 25 & Roystonea regia & Palem raja & 1 & 2 & 3 & 3 & 2 & 11 & 20 & 55 & $\begin{array}{l}\text { Kurang } \\
\text { sesuai }\end{array}$ \\
\hline 26 & Salyx babilonica & Salix/liang liu & 1 & 2 & 4 & 3 & 1 & 11 & 20 & 55 & $\begin{array}{l}\text { Kurang } \\
\text { sesuai }\end{array}$ \\
\hline 27 & Samanea saman & Saman & 4 & 2 & 4 & 4 & 4 & 18 & 20 & 90 & Sangat sesuai \\
\hline 28 & $\begin{array}{l}\text { Schefflera } \\
\text { actinophylla }\end{array}$ & Walisongo & 3 & 1 & 3 & 3 & 1 & 11 & 20 & 55 & $\begin{array}{l}\text { Kurang } \\
\text { sesuai }\end{array}$ \\
\hline 29 & $\begin{array}{l}\text { Spatodhea } \\
\text { campanulata }\end{array}$ & Kecrutan & 4 & 1 & 3 & 3 & 3 & 14 & 20 & 70 & Sesuai \\
\hline 30 & Tectona grandis & Jati & 1 & 1 & 3 & 2 & 3 & 10 & 20 & 50 & $\begin{array}{l}\text { Kurang } \\
\text { sesuai }\end{array}$ \\
\hline 31 & Veitchia merilii & Palem putri & 2 & 2 & 3 & 2 & 2 & 11 & 20 & 55 & $\begin{array}{l}\text { Kurang } \\
\text { sesuai }\end{array}$ \\
\hline 32 & Wodyetia bifurcata & $\begin{array}{l}\text { Palem ekor } \\
\text { tupai }\end{array}$ & 1 & 2 & 3 & 3 & 3 & 12 & 20 & 60 & $\begin{array}{l}\text { Kurang } \\
\text { sesuai }\end{array}$ \\
\hline
\end{tabular}

Keterangan

K1 : Kepadatan tajuk

K2 : Terdiri atas beberapa lapis tanaman dan terdapat kombinasi dengan semak, perdu dan groundcover.

K3 : Daun tipis

K4 : Jumlah daun banyak

K5 : Jarak tanam rapat 

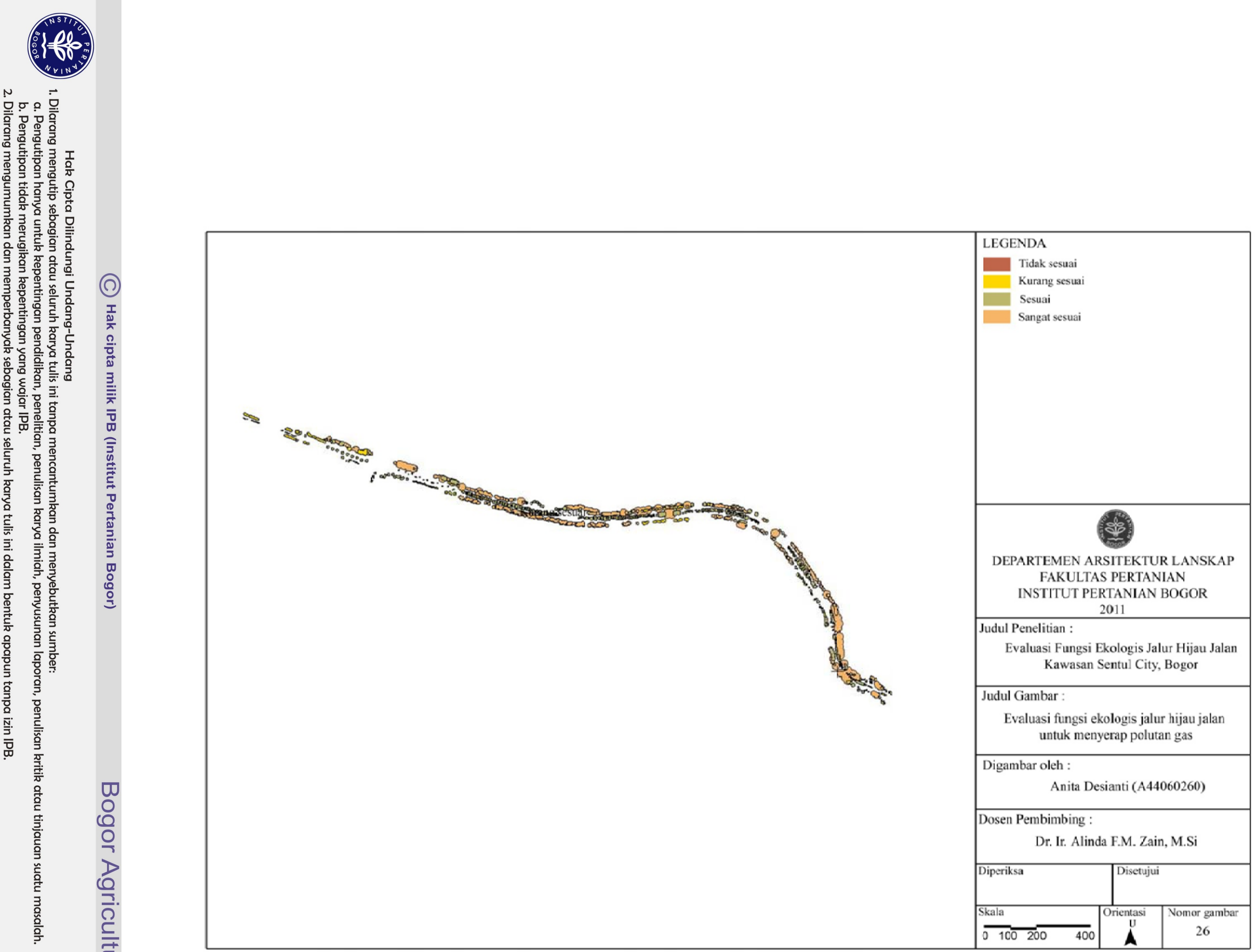
Tanaman yang sesuai untuk fungsi penyerap polutan gas antara lain Bauhinia blakeana, Bucida molineti, Dillenia philipinensis, Elaeis guineensis, Erythrina cristagalli, Ficus lyrata, Ficus sp, Filicium decipiens, Paraserianthes falcataria, dan Spatodhea campanulata. Tanaman-tanaman ini umumnya memiliki tajuk yang padat sampai cukup padat, jumlah daun relatif banyak, dan jarak tanam yang cukup rapat serta dilakukan dalam lapisan dan sebagian besar dikombinasikan dengan penanaman semak dan groundcover.

Tanaman yang kurang sesuai untuk fungsi penyerap polutan gas adalah tanaman-tanaman dengan penanaman kurang rapat, soliter, atau sedikit sekali kombinasi dengan semak dan groundcover. Sebagian besar tanaman yang kurang sesuai berasal dari tanaman palem-paleman dengan tajuk yang tidak rapat dan jumlah daun sedikit walaupun ada beberapa pohon berdaun lebar yang memiliki tajuk kurang rapat atau jumlah daun yang sedikit. Tanaman yang kurang sesuai untuk fungsi reduksi polusi yaitu Bismarckia nobilis, Cocos nucifera, Gmelina arborea, Livistona rotundifolia, Pandanus sp, Phoenix roebelenii, Plumeria rubra, Ravenala madagascariensis, Roystonea regia, Salyx babilonica, Schefflera actinophylla, Tectona grandis, Veitchia merilii, Wodyetia bifurcata, dan Chrysalidocarpus lutescens.

Tanaman yang tidak sesuai untuk fungsi penyerap polutan gas antara lain Cordyline australis dan Pandanus utilis. Kedua tanaman ini merupakan jenis-jenis tanaman focal point yang ditanam sedikit dan pada lokasi-lokasi tertentu saja seperti di area pintu masuk. Tanaman-tanaman ini memiliki daun yang tebal dan julah daun relatif sedikit serta tajuk yang tidak padat.

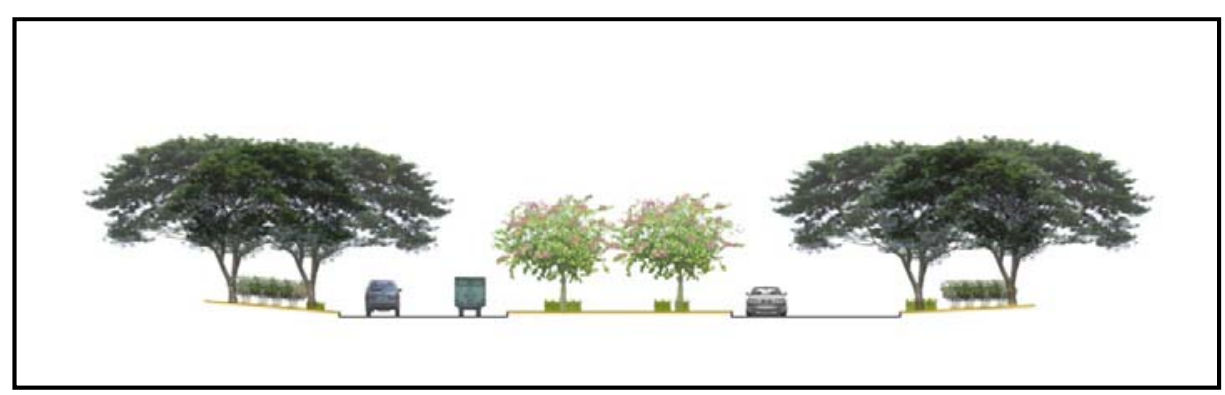

Gambar 27 Potongan tampak jalur hijau jalan sebagai penyerap polutan gas 
Dari penilaian yang telah dilakukan, didapatkan hasil bahwa 5 jenis pohon sangat sesuai untuk menyerap polutan gas, 11 jenis pohon sesuai untuk fungsi penyerap polutan gas, 14 jenis kurang sesuai untuk penyerap polutan gas, dan 2 jenis tidak sesuai untuk penyerap polutan gas. Dari hasil ini diketahui bahwa 16 jenis pohon pada jalur hijau jalan $\mathrm{MH}$ Thamrin berpotensi sebagai pereduksi polusi. Kesesuaian menggambarkan apakah pohon-pohon jalan yang ada sudah cukup memiliki ciri fisik yang kondisi lapang yang mendukung untuk menyerap polutan gas.

Setelah mendapatkan kesesuaian pohon, dihitung luasan pohon. Luasan jenis pohon untuk masing-masing kategori jenis sangat sesuai, sesuai, kurang sesuai, dan tidak sesuai merupakan gambaran luas jalur hijau jalan untuk tiap kategori tersebut. Untuk kategori sangat sesuai, 5 jenis pohon yang sangat sesuai memiliki luas $68259 \mathrm{~m}^{2}$. Luas tersebut menempati 63,54\% dari luas RTH yang dipetakan. Kategori jalur hijau jalan yang sesuai, 10 jenis pohon yang dikategorikan sesuai memiliki luas $24357 \mathrm{~m}^{2}$ dan luas tersebut memiliki persentase luas 22,67 \%. Untuk kategori jalur hijau jalan yang kurang sesuai, 15 jenis pohon yang kurang sesuai memiliki luas $14767 \mathrm{~m}^{2}$ dan luas tersebut memiliki persentase luas 13,75 \%. Kategori jalur hijau jalan yang tidak sesuai untuk fungsi ini, terdiri dari 2 jenis pohon dengan luas $52 \mathrm{~m}^{2}$ dan luas tersebut memiliki persentase luas $0,05 \%$.

Tabel 15 Hasil evaluasi kesesuaian pohon untuk fungsi penyerap polutan gas

\begin{tabular}{cccc}
\hline Kesesuaian fungsi reduksi polusi & Jenis & Luasan $\left(\mathrm{m}^{2}\right)$ & Proporsi luas (\%) \\
\hline Sangat sesuai & 5 & 68259 & 63.54 \\
\hline Sesuai & 10 & 24357 & 22.67 \\
\hline Kurang sesuai & 15 & 14767 & 13.75 \\
\hline Tidak sesuai & 2 & 52 & 0.05 \\
\hline Total & 32 & 107435 & 100 \\
\hline
\end{tabular}

Dari luas keseluruhan vegetasi yang dipetakan, jalur hijau jalan yang sangat sesuai dan sesuai menempati 63,54 \% dan 22,67 \% luas keseluruhan. Jumlah luasan kedua kategori ini lebih banyak dibandingkan luas yang kurang sesuai dan tidak sesuai yaitu 13,75 \% dan 0,05 \%. Hal ini menunjukkan bahwa 
pada jalur hijau jalan $\mathrm{MH}$ Thamrin sudah terdapat jenis-jenis tanaman yang berpotensi untuk menyerap polutan gas.

\subsubsection{Evaluasi Fungsi Ekologis Penjerap Partikel}

Ruang terbuka hijau dapat mengurangi tingkat pencemaran partikel. Partikel direduksi oleh ruang terbuka hijau dengan penjerapan pada permukaan tanaman. Tingkat pencemaran udara dan partikel pada jalan relatif tinggi terkait dengan penggunaan kendaraan bermotor pada sistem transportasi kota. Penilaian ini untuk mengetahui fungsi ekologis ruang terbuka hijau jalan untuk menjerap partikel.

Penilaian terhadap vegetasi lanskap jalan untuk penjerap partikel difokuskan pada pohon-pohon di tepi jalan, median dan traffic islands. Penilaian dilakukan dengan membandingkan kondisi pohon pada lokasi penelitian dengan standar jenis vegetasi yang efektif dalam menjerap partikel yang dirangkum dari berbagai literatur terkait. Kriteria yang dipilih untuk penilaian terutama yang dapat diamati secara langsung.

Kriteria penilaian untuk fungsi pohon sebagai penjerap partikel terdiri dari empat kriteria penilaian. Kriteria penilaian tersebut yaitu permukaan daun yang kasar, berlekuk, berbulu/bertrikoma, daun berupa daun jarum atau daun lebar, tajuk rimbun dan rapat, dan memiliki tekstur kulit batang dan ranting yang kasar, serta terdapat sisik atau duri pada ranting. Hal yang paling berperan dalam penjerapan partikel adalah kekasaran permukaan penjerapnya. Karena itu, tanaman dengan permukaan daun yang kasar atau tekstur batang kasar dapat menjerap partikel dengan lebih baik.

Struktur daun merupakan salah satu hal yang mempengaruhi penjerapan partikel. Daun yang baik untuk menjerap partikel adalah daun dengan permukaan kasar, berbulu, berlekuk. Partikel akan menempel pada permukaan kasar dan tidak mudah lepas. Pada permukaan yang licin, partikel mudah lepas dari permukaannya (Dahlan, 2004). Daun yang bertrikoma/berbulu mengendapkan partikel lebih banyak dibanding daun tanpa trikoma/rambut (Grey dan Deneke, 1978). Luas daun turut mempengaruhi penjerapan partikel. Daun yang lebar serta 
daun jarum cukup efektif dalam penjerapan partikel karena luas permukaan untuk menjerap partikel yang cukup tinggi.

Bidang penjerap partikel pada pohon tidak terbatas pada permukaan daun saja melainkan juga permukaan batang dan ranting. Batang dengan tekstur kasar lebih baik dalam menjerap partikel dibandingkan batang berkulit halus atau licin. Ranting yang bersisik, berduri, atau bertekstur kasar lebih efektif dalam menjerap partikel dibanding ranting yang licin (Dahlan, 1989). Massa tajuk yang rapat dan padat lebih efektif dalam menjerap partikel dibanding tajuk yang terbuka. Struktur ranting yang padat juga turut mempengaruhi penjerapan partikel pada pohon.

Dari hasil penilaian, diketahui jenis tanaman yang sangat sesuai, sesuai, kurang sesuai, dan tidak sesuai untuk menjerap partikel. Tanaman yang sangat sesuai untuk fungsi penjerap partikel antara lain Araucaria heterophylla dan Pinus merkusii. Kedua jenis tanaman ini memiliki jenis daun jarum yang baik dalam menjerap partikel. Tekstur batang Araucaria heterophylla kasar dan rantingnya berduri. Sementara tekstur batang Pinus merkusii kasar dan bagian ranting dekat daun bersisik. Kedua jenis tekstur batang dan ranting ini dinilai cukup efektif untuk penjerapan partikel.

Tanaman yang sesuai untuk menjerap partikel antara lain Bauhinia blakeana, Dillenia philipinensis, Erythrina christagalli, Ficus lyrata, Filicium decipiens, Gmelina arborea, Spatodhea campanulata dan Samanea saman. Tanaman-tanaman ini memiliki daun besar sampai cukup besar dengan permukaan yang cukup kasar dan beberapa jenis pohon seperti Samanea saman, Bauhinia purpurea, dan Gmelina arborea memiliki daun bertrikoma. Tanamantanaman yang sesuai tersebut memiliki tekstur batang yang relatif kasar. Tajuk pohon-pohon tersebut cenderung padat kecuali untuk Gmelina arborea yang cukup terbuka. Walaupun Gmelina arborea berdasarkan penilaian sesuai, tanaman tersebut merupakan jenis gugur daun yang kurang disarankan untuk penanaman dengan fungsi mengurangi polusi udara. 
Tabel 16 Evaluasi fungsi penjerap partikel

\begin{tabular}{|c|c|c|c|c|c|c|c|c|c|c|c|}
\hline No & Nama latin & Nama lokal & $\begin{array}{l}\mathrm{K} \\
1 \\
\end{array}$ & $\begin{array}{l}\mathrm{K} \\
2 \\
\end{array}$ & $\begin{array}{l}\mathrm{K} \\
3 \\
\end{array}$ & $\begin{array}{l}\mathrm{K} \\
4 \\
\end{array}$ & $\begin{array}{l}\mathrm{K} \\
5 \\
\end{array}$ & $\begin{array}{c}\text { Nilai } \\
\text { aktual }\end{array}$ & $\begin{array}{l}\text { Nilai } \\
\text { Standar }\end{array}$ & $\begin{array}{c}\text { Nilai } \\
\text { evaluasi } \\
(\%)\end{array}$ & Kesesuaian \\
\hline 1 & Acacia mangium & Akasia & 1 & 3 & 4 & 3 & 3 & 14 & 20 & 70 & Sesuai \\
\hline 2 & $\begin{array}{l}\text { Araucaria } \\
\text { heterophylla }\end{array}$ & $\begin{array}{l}\text { Cemara } \\
\text { norflok }\end{array}$ & 4 & 4 & 3 & 4 & 3 & 18 & 20 & 90 & Sangat sesuai \\
\hline 3 & Bauhinia blakeana & $\begin{array}{l}\text { Bunga } \\
\text { kupu-kupu }\end{array}$ & 3 & 3 & 3 & 2 & 3 & 14 & 20 & 70 & Sesuai \\
\hline 4 & Bismarckia nobilis & $\begin{array}{l}\text { Palem } \\
\text { Bismarck }\end{array}$ & 3 & 3 & 2 & 3 & 1 & 12 & 20 & 60 & $\begin{array}{l}\text { Kurang } \\
\text { sesuai }\end{array}$ \\
\hline 5 & Bucida molineti & Ketapang & 2 & 1 & 3 & 1 & 4 & 11 & 20 & 55 & $\begin{array}{l}\text { Kurang } \\
\text { sesuai }\end{array}$ \\
\hline 6 & $\begin{array}{l}\text { Chrysalidocarpus } \\
\text { lutescens }\end{array}$ & $\begin{array}{l}\text { Palem } \\
\text { kuning }\end{array}$ & 1 & 2 & 2 & 1 & 1 & 7 & 20 & 35 & Tidak sesuai \\
\hline 7 & Cocos nucifera & Kelapa & 1 & 3 & 1 & 2 & 1 & 8 & 20 & 40 & Tidak sesuai \\
\hline 8 & Cordyline australis & Pandan bali & 1 & 3 & 1 & 1 & 1 & 7 & 20 & 35 & Tidak sesuai \\
\hline 9 & Dillenia philipinensis & Sempur & 2 & 3 & 4 & 2 & 4 & 15 & 20 & 75 & Sesuai \\
\hline 10 & Elaeis guineensis & $\begin{array}{l}\text { Kelapa } \\
\text { sawit }\end{array}$ & 2 & 3 & 4 & 2 & 1 & 12 & 20 & 60 & $\begin{array}{l}\text { Kurang } \\
\text { sesuai }\end{array}$ \\
\hline 11 & Erythrina cristagalli & $\begin{array}{l}\text { Dadap } \\
\text { merah }\end{array}$ & 3 & 3 & 2 & 4 & 4 & 16 & 20 & 80 & Sesuai \\
\hline 12 & Ficus benjamina & Beringin & 1 & 1 & 4 & 2 & 4 & 12 & 20 & 60 & $\begin{array}{l}\text { Kurang } \\
\text { sesuai }\end{array}$ \\
\hline 13 & Ficus lyrata & $\begin{array}{l}\text { Biola } \\
\text { cantik }\end{array}$ & 2 & 3 & 3 & 2 & 3 & 13 & 20 & 65 & Sesuai \\
\hline 14 & Ficus $s p$. & Beringin & 1 & 3 & 4 & 1 & 3 & 12 & 20 & 60 & $\begin{array}{l}\text { Kurang } \\
\text { sesuai }\end{array}$ \\
\hline 15 & Filicium decipiens & $\begin{array}{l}\text { Kerai } \\
\text { payung }\end{array}$ & 2 & 1 & 4 & 3 & 3 & 13 & 20 & 65 & Sesuai \\
\hline 16 & Gmelina arborea & Jati putih & 4 & 3 & 3 & 2 & 3 & 15 & 20 & 75 & Sesuai \\
\hline 17 & Livistona rotundifolia & $\begin{array}{l}\text { Palem } \\
\text { sadeng }\end{array}$ & 2 & 3 & 1 & 1 & 1 & 8 & 20 & 40 & Tidak sesuai \\
\hline 18 & Pandanus sp. & Pandan & 2 & 3 & 3 & 1 & 1 & 10 & 20 & 50 & $\begin{array}{l}\text { Kurang } \\
\text { sesuai }\end{array}$ \\
\hline 19 & Pandanus utilis & $\begin{array}{l}\text { Pandan } \\
\text { melintir }\end{array}$ & 2 & 3 & 1 & 1 & 3 & 10 & 20 & 50 & $\begin{array}{l}\text { Kurang } \\
\text { sesuai }\end{array}$ \\
\hline 20 & $\begin{array}{l}\text { Paraserianthes } \\
\text { falcataria }\end{array}$ & Sengon & 2 & 1 & 2 & 2 & 2 & 9 & 20 & 45 & $\begin{array}{l}\text { Kurang } \\
\text { sesuai }\end{array}$ \\
\hline 21 & Phoenix roebelenii & Phoenix & 2 & 2 & 2 & 3 & 1 & 10 & 20 & 50 & $\begin{array}{l}\text { Kurang } \\
\text { sesuai }\end{array}$ \\
\hline 22 & Pinus merkusii & Pinus & 4 & 4 & 3 & 4 & 3 & 18 & 20 & 90 & Sangat sesuai \\
\hline 23 & Plumeria rubra & Kamboja & 2 & 3 & 2 & 1 & 3 & 11 & 20 & 55 & $\begin{array}{l}\text { Kurang } \\
\text { sesuai }\end{array}$ \\
\hline 24 & $\begin{array}{l}\text { Ravenala } \\
\text { madagascariensis }\end{array}$ & $\begin{array}{l}\text { Pisang } \\
\text { kipas }\end{array}$ & 1 & 3 & 1 & 2 & 1 & 8 & 20 & 40 & Tidak sesuai \\
\hline 25 & Roystonea regia & Palem raja & 1 & 3 & 2 & 1 & 1 & 8 & 20 & 40 & Tidak sesuai \\
\hline 26 & Salyx babilonica & $\begin{array}{l}\text { Salix/liang } \\
\text { liu }\end{array}$ & 1 & 1 & 1 & 1 & 2 & 6 & 20 & 30 & Tidak sesuai \\
\hline 27 & Samanea saman & Saman & 3 & 1 & 4 & 3 & 4 & 15 & 20 & 75 & Sesuai \\
\hline 28 & $\begin{array}{l}\text { Schefflera } \\
\text { actinophylla }\end{array}$ & Walisongo & 2 & 3 & 4 & 2 & 3 & 14 & 20 & 70 & Sesuai \\
\hline 29 & $\begin{array}{l}\text { Spatodhea } \\
\text { campanulata }\end{array}$ & Kecrutan & 2 & 2 & 3 & 3 & 3 & 13 & 20 & 65 & Sesuai \\
\hline 30 & Tectona grandis & Jati & 4 & 3 & 1 & 2 & 2 & 12 & 20 & 60 & $\begin{array}{l}\text { Kurang } \\
\text { sesuai }\end{array}$ \\
\hline 31 & Veitchia merilii & Palem putri & 1 & 2 & 1 & 2 & 1 & 7 & 20 & 35 & Tidak sesuai \\
\hline 32 & Wodyetia bifurcata & $\begin{array}{l}\text { Palem ekor } \\
\text { tupai }\end{array}$ & 1 & 2 & 1 & 2 & 1 & 7 & 20 & 35 & Tidak sesuai \\
\hline
\end{tabular}

\section{Keterangan :}

K1 : Struktur permukaan dan tepi daun kasar, berlekuk, berbulu/bertrikoma

K2 : Daun jarum atau daun lebar

K3 : Tajuk rimbun dan rapat

K4 : Tekstur kulit batang dan ranting kasar, ranting berduri

K5 : Kepadatan ranting 

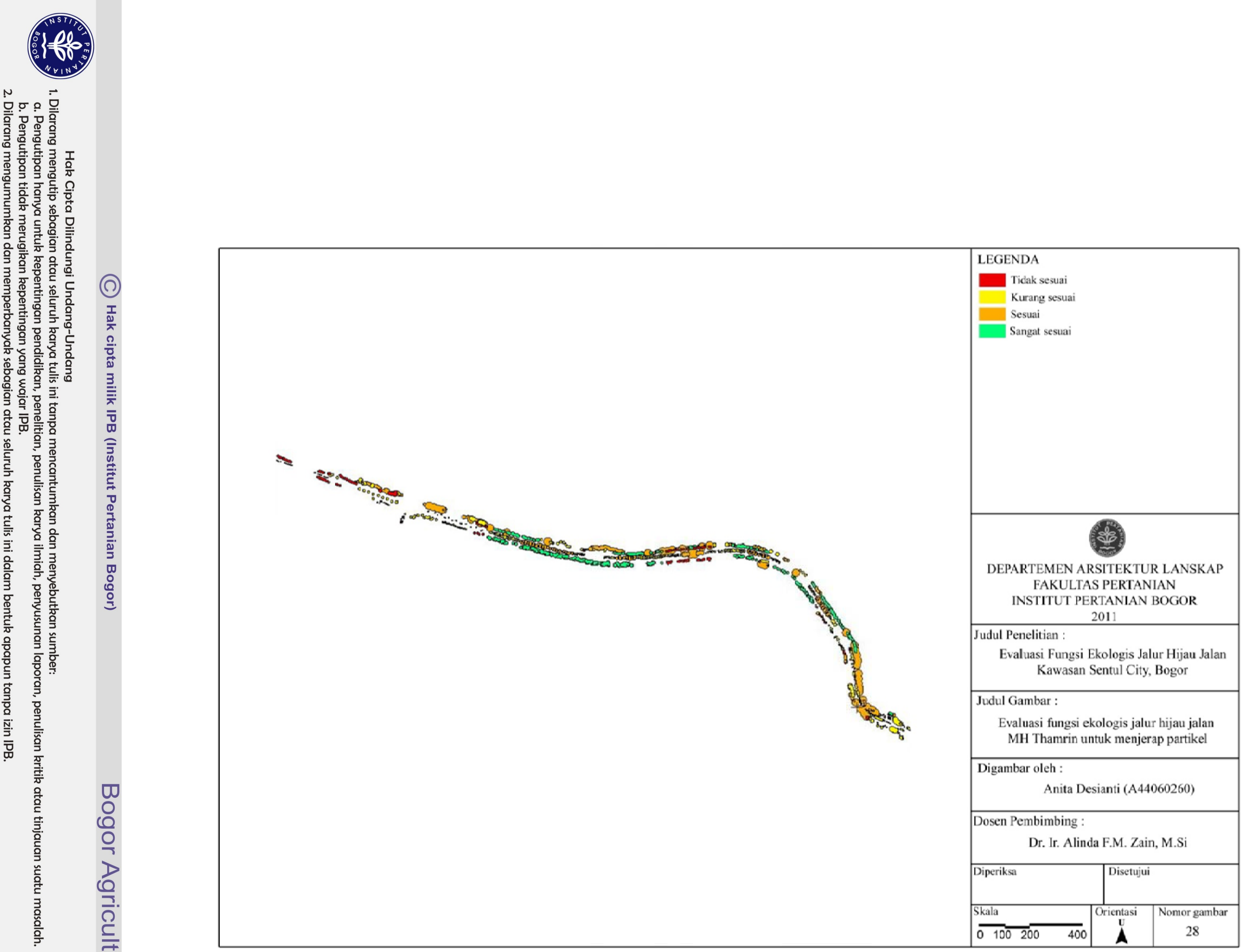
Tanaman yang kurang sesuai untuk fungsi penjerap partikel merupakan tanaman dengan beberapa ciri fisik yang mencukupi untuk penjerapan partikel namun kurang baik pada beberapa ciri lainnya seperti tajuk yang tidak padat, daun licin dan kecil, serta tekstur permukaan batang yang relatif tidak terlalu kasar. Tectona grandis memiliki daun yang baik untuk penjerapan partikel namun tajuk kurang rapat serta tekstur permukaan batang tidak terlalu kasar. Tanaman yang juga kurang sesuai yaitu Plumeria rubra, Bucida molineti, Ficus benjamina, Ficus sp, Paraserianthes falcataria, Elaeis guineensis, Pandanus utilis, Pandanus sp, dan Bismarckia nobilis. Plumeria rubra memiliki daun yang cukup kasar namun tajuk serta percabangan tidak padat. Tanaman-tanaman bertajuk rapat sampai cukup rapat seperti Bucida molineti, Ficus benjamina, Ficus sp, Paraserianthes falcataria, dan Elaeis guineensis memiliki keterbatasan pada bentuk daun yang kecil atau permukaan daun yang licin. Pandanus utilis, Pandanus sp, dan Bismarckia nobilis memiliki daun yang lebar namun licin yang kurang dapat menjerap partikel, tajuk tidak telalu padat kecuali untuk Pandanus sp yang cukup padat, dan tidak terdapat percabangan sehingga luas permukaan untuk penjerapan partikel kurang. Phoenix roebelenii memiliki batang dengan duri-duri yang besar dan cukup kasar namun permukaan daun licin dan tajuk tidak cukup rapat sehingga kurang sesuai untuk penjerapan partikel.

Tanaman yang tidak sesuai untuk menjerap partikel banyak merupakan jenis palem yang memiliki daun dengan permukaan relatif licin, tajuk yang tidak rapat, permukaan batang tidak terlalu kasar dan cenderung halus. Tanamantanaman ini yaitu Chrysalidocarpus lutescens, Cocos nucifera, Livistona rotundifolia, Roystonea regia, Veitchia merilii, dan Wodyetia bifurcata. Ravenala madagascariensis memiliki daun cukup licin dan tajuk yang tidak rapat. Salyx babilonica tidak sesuai untuk penjerap partikel karena batangnya bertekstur halus, daun kecil, serta tajuk yang tidak rapat. Cordyline australis juga termasuk tanaman yang tidak sesuai untuk penjerap partikel karena daunnya licin, tajuk tidak rapat, dan batangnya bertekstur halus. 


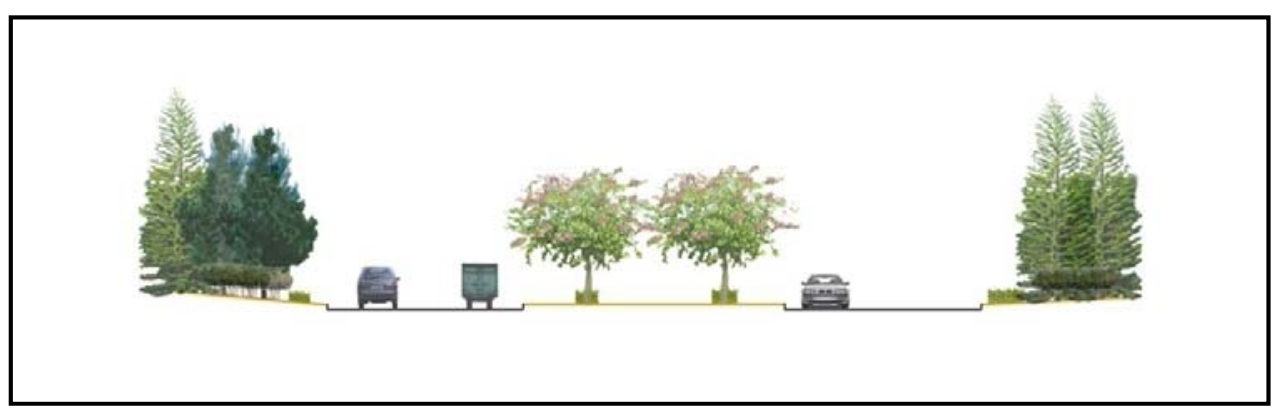

Gambar 29 Potongan tampak jalur hijau jalan untuk menjerap partikel

Dari penilaian yang telah dilakukan, didapatkan hasil bahwa 2 jenis pohon sangat sesuai untuk fungsi ekologis penjerap partikel, 10 jenis pohon sesuai untuk fungsi penjerap partikel, 11 jenis kurang sesuai untuk penjerap partikel, dan 9 jenis tidak sesuai untuk penjerap partikel. Dari hasil penilaian tersebut diketahui bahwa 12 jenis pohon pada jalur hijau jalan MH Thamrin berpotensi untuk fungsi penjerap partikel. Tanaman-tanaman yang kurang sesuai berjumlah 11 jenis cukup berpotensi untuk fungsi penjerap partikel namun harus diberi perlakuan tertentu agar fungsi penjerap partikel dapat lebih optimal. Tanaman yang tidak sesuai untuk fungsi menjerap partikel terdiri dari 9 jenis.

Dari jenis-jenis yang telah diketahui kesesuaiannya tersebut, ditentukan luasan untuk tiap kategori kesesuaian. Luasan jenis pohon untuk masing-masing kategori jenis sangat sesuai, sesuai, kurang sesuai, dan tidak sesuai menggambarkan luas jalur hijau jalan untuk tiap kategori tersebut. Untuk kategori sangat sesuai, 2 jenis pohon yang sangat sesuai memiliki luas $33.292 \mathrm{~m}^{2}$. Luas tersebut menempati 30,99 \% dari luas jalur hijau jalan yang dipetakan. Kategori jalur hijau jalan sesuai, 10 jenis pohon yang dikategorikan sesuai memiliki luas $42.881 \mathrm{~m}^{2}$ dan luas tersebut memiliki persentase luas 39,91 \%. Untuk kategori jalur hijau jalan kurang sesuai, 11 jenis pohon yang kurang sesuai memiliki luas $22.962 \mathrm{~m}^{2}$ dan luas tersebut memiliki persentase luas 21,37 \%. Kategori jalur hijau jalan yang tidak sesuai untuk fungsi ini, terdiri dari 9 jenis pohon dengan luas $8300 \mathrm{~m}^{2}$ dan luas tersebut memiliki persentase luas 7,73\%. 
Tabel 17 Hasil evaluasi kesesuaian untuk fungsi penjerap partikel

\begin{tabular}{cccc}
\hline $\begin{array}{c}\text { Kesesuaian fungsi penjerap } \\
\text { partikel }\end{array}$ & $\begin{array}{c}\text { Jumlah } \\
\text { jenis }\end{array}$ & Luasan $\left(\mathrm{m}^{2}\right)$ & Proporsi luas (\%) \\
\hline Sangat sesuai & 2 & 33292 & 30.99 \\
\hline Sesuai & 10 & 42881 & 39.91 \\
\hline Kurang sesuai & 11 & 22962 & 21.37 \\
\hline Tidak sesuai & 9 & 8300 & 7.73 \\
\hline Total & 32 & 107435 & 100 \\
\hline
\end{tabular}

Dari luas keseluruhan yang dipetakan, jalur hijau jalan yang sangat sesuai dan sesuai menempati 30,99 \% dan 39,91 \% luas keseluruhan. Jumlah luasan kedua kategori ini lebih banyak dibandingkan luas yang kurang sesuai dan tidak sesuai yaitu 21,37\% dan 7,73 \%. Hal ini menunjukkan bahwa pada jalur hijau jalan MH Thamrin sudah terdapat jenis-jenis tanaman yang berpotensi untuk menjerap partikel.

\subsection{Rekomendasi}

Pemilihan vegetasi untuk tujuan kontrol polusi perlu memperhatikan beberapa hal yaitu tipe pohon, dimensi pohon, tingkat pertumbuhan, karakteristik daun, dan toleransi terhadap polusi udara (Yang et.al, 2005). Tipe pohon evergreen umumnya memiliki tingkat efisiensi yang lebih tinggi dalam membersihkan polutan udara karena masa hidup yang lebih lama. Dimensi atau besar pohon menggambarkan jumlah karbon dioksida yang dapat disimpan serta luas permukaan untuk intersepsi dan deposisi. Tingkat pertumbuhan pohon mempengaruhi penyimpanan tahunan karbondioksida dan ukuran permukaan tajuk fungsional untuk pembersihan polutan udara. Tanaman dengan tingkat pertumbuhan yang cepat dapat menyimpan karbondioksida serta menyediakan permukaan penyerap polusi udara lebih awal dibanding dengan tanaman lainnya. Karakter daun suatu tanaman akan mempengaruhi tingkat deposisi polutan. Daun yang berambut, memiliki resin, berduri, dan kasar dapat menangkap partikel lebih baik dibanding daun yang halus.

Jenis pohon yang dipilih untuk fungsi mengurangi pencemaran udara terutama adalah jenis yang dapat mereduksi zat pencemar. Jenis yang dipilih antara lain adalah jenis yang dapat menyerap $\mathrm{NO}_{2}$ atau $\mathrm{CO}_{2}$ dengan baik, contoh 
tanaman terlampir pada tabel lampiran 4 dan 5. Jenis pohon untuk fungsi menyerap polutan gas antara lain yaitu jenis dengan ketahanan terhadap jenis polutan udara, memiliki kemampuan dalam mengurangi pencemar udara, berdaun sepanjang tahun, tajuk rapat, berdaun banyak, dan penanaman yang dikombinasikan dengan semak dan perdu. Sementara itu, untuk fungsi menjerap partikel jenis pohon dengan karakter daun kasar, berbulu dan bersisik permukaan ranting dan batang yang kasar, kepadatan ranting, daun jarum atau daun lebar dan memiliki luas permukaan penjerapan tinggi.

Penanaman vegetasi dengan kombinasi antara pohon, semak, dan perdu akan efektif untuk menyerap polusi udara. Vegetasi ditanam sebanyak beberapa lapis tanaman dengan penanaman yang kontinyu. Grey dan Deneke (1978) menyebutkan bahwa penanaman untuk mereduksi polutan sebaiknya meempertimbangkan arah angin untuk penyebaran gas pencemar sehingga konsentrasinya berkurang.

Dari hasil penelitian diketahui bahwa pada saat ini pergerakan kendaraan kawasan Sentul City masih rendah. Kondisi ini berbeda dengan kondisi jalan kota pada umumnya yang padat. Pada jalur hijau jalan $\mathrm{MH}$ Thamrin, jumlah zat pencemar yang terukur masih jauh di bawah baku mutu. Hal ini menunjukkan tingkat polusi dalam kawasan masih dangat rendah. Evaluasi jalur hijau jalan yang telah dilakukan menghasilkan rekomendasi sebagai berikut.

\subsubsection{Jalur Hijau Jalan Untuk Menyerap Polutan Gas}

Hasil penilaian terhadap fungsi ekologis jalur hijau jalan untuk menyerap polutan gas menunjukkan terdapat kategori vegetasi yang sangat sesuai, sesuai, kurang sesuai, dan tidak sesuai. Rekomendasi dijelaskan sebagai berikut.

\section{Kategori sangat sesuai}

Kategori vegetasi jalur hijau jalan ini memenuhi kriteria-kriteria untuk fungsi menyerap polutan gas. Pada jalur hijau jalan $\mathrm{MH}$ Thamrin, vegetasi yang sangat sesuai yaitu 63,54 \% dari luas vegetasi. Hasil ini menunjukkan, kondisi penanaman saat ini sudah cukup baik untuk fungsi menyerap polutan gas. Jalur hijau jalan ini diharapkan dipertahankan karena memiliki potensi yang baik dalam menyerap polutan gas. 

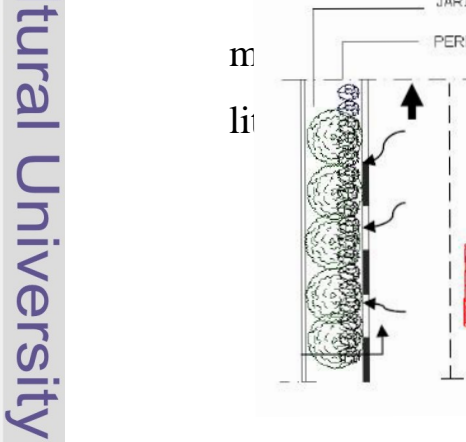
banyak dapat menyerap gas pencemar lebih baik dibanding tanaman berdaun lebar tapi jumlah daunnya sedikit. Pohon dengan tajuk padat lebih efektif dalam mereduksi polusi. Pohon untuk mereduksi polusi dapat dipilih jenis yang toleran. Jenis pohon yang sensitif terhadap polutan tertentu sebaiknya tidak ditanam dekat dengan sumber polusi. Penanaman vegetasi dapat dilakukan dalam beberapa lapis tanaman karena area penyangga yang lebih tebal dapat mereduksi polusi dengan lebih baik. Selain itu, penanaman dilakukan kontinyu dan dapat mengkombinasikan pohon dengan semak dan groundcover. Dengan adanya kombinasi antara pohon, perdu, semak dan groundcover terjadi strata vegetasi secara vertikal. Pepohonan yang lebih tinggi dapat menangkap zat pencemar pada lokasi yang lebih tinggi dan semak dapat menyerap dan menangkap zat pencemar udara pada ketinggian yang lebih rendah.

\subsubsection{Jalur Hijau Jalan Untuk Menjerap Partikel}

Hasil dari penilaian terhadap fungsi ekologis jalur hijau jalan untuk menjerap partikel yaitu diketahuinya jalur hijau jalan yang sangat sesuai, sesuai, kurang sesuai, dan tidak sesuai. Rekomendasi dijelaskan sebagai berikut.

\section{Kategori sangat sesuai}

Luas vegetasi jalur hijau jalan yang sangat sesuai menempati 30,99 \% luas jalur hijau jalan. Kategori jalur hijau jalan sangat sesuai telah memenuhi kriteriakriteria untuk fungsi menjerap partikel. Jalur hijau jalan diharapkan dipertahankan karena memiliki potensi yang baik dalam menjerap partikel. Jenis pohon yang sangat sesuai untuk menjerap partikel dipertahankan dan dapat ditambah penanamannya pada lokasi-lokasi yang masih memungkinkan atau pada pengembangan selanjutnya.

\section{Kategori sesuai}

Kategori jalur hijau jalan ini memenuhi sebagian besar kriteria untuk fungsi menjerap partikel. Luasan jalur hijau jalan yang sesuai untuk menjerap partikel yaitu sebesar 39,91 \%. Jalur hijau jalan berpotensi dalam menjerap partikel dan diharapkan dipertahankan. Jenis pohon yang sesuai untuk menjerap partikel dipertahankan. Penanaman pohon yang sesuai dapat ditambah jumlahnya. 


\section{Kategori kurang sesuai}

Kategori jalur hijau jalan ini cukup berpotensi dalam menjerap partikel dan memiliki luas 21,37\% luas jalur hijau jalan. Jalur hijau jalan dapat dipertahankan namun diberi penambahan pohon atau elemen tanaman lainnya. Hal ini dilakukan untuk menambah luas permukaan penjerapan sehingga penjerapan lebih efektif. Penambahan penanaman dapat dilakukan dan dengan menggunakan jenis tanaman yang sesuai untuk menjerap partikel.

\section{Kategori tidak sesuai}

Kategori jalur hijau jalan ini tidak memenuhi sebagian besar kriteria untuk menjerap partikel. Luasan jalur hijau jalan tidak sesuai pada yaitu 7,73\%. Pemanfaatan jalur hijau jalan ini untuk fungsi menjerap partikel dapat dilakukan dengan memodifikasi dan menambahkan penanaman pohon dan semak. Jenis yang dipilih yaitu jenis bermassa daun padat dan memiliki karakteristik pohon penjerap partikel. Penanaman dilakukan pada jarak tanam yang rapat untuk mengefektifkan penjerapan.

Untuk fungsi menjerap partikel, pohon yang digunakan diutamakan memiliki permukaan yang kasar. Permukaan yang kasar dapat menjerap partikel dengan lebih efektif karena partikel akan lebih mudah menempel pada permukaaan yang kasar. Penanaman vegetasi dalam beberapa lapis tanaman dapat menjerap partikel dengan lebih baik. Penanaman pohon dapat ditambahkan dengan penanaman tanaman yang lebih rendah seperti semak dan perdu. Penanaman tambahan ini dapat menambah luas permukaan penjerapan dan membentuk struktur vegetasi yang lebih rapat sehingga penjerapan partikel dapat lebih efektif. 


\section{BAB VI \\ PENUTUP}

\subsection{Simpulan}

Berdasarkan hasil studi didapatkan beberapa simpulan sebagai berikut.

1. Pada jalan $\mathrm{MH}$ Thamrin ruang terbuka hijau berbentuk jalur hijau jalan. Jalur hijau jalan pada lanskap jalan MH Thamrin disediakan pada jalur tepi, median, dan traffic islands. Pada jalur hijau jalan tersebut, telah terdapat beberapa jenis tanaman yang toleran terhadap polusi udara dan berkapasitas dalam menyerap zat-zat pencemar antara lain nitrogen dioksida dan karbon dioksida.

2. Dari hasil analisis diketahui tingkat polusi gas dan partikel masih berada di bawah ambang batas baku mutu kualitas udara ambient. Hal ini menunjukkan bahwa tingkat pencemaran udara pada kawasan masih rendah.

3. Hasil penilaian jalur hijau jalan untuk fungsi ekologis penyerap polutan gas yaitu 5 jenis pohon sangat sesuai untuk fungsi ekologis penyerap polutan gas dengan luas 63,54 \%, 10 jenis pohon sesuai untuk fungsi penyerap polutan gas dengan luas 22,67 \%, 15 jenis kurang sesuai untuk penyerap polutan gas dengan luas 13,75 \%, dan dan 2 jenis tidak sesuai untuk penyerap polutan gas dengan luas $0,05 \%$.

4. Hasil penilaian jalur hijau jalan untuk fungsi ekologis penjerap partikel yaitu 2 jenis pohon sangat sesuai untuk fungsi ekologis penjerap partikel dengan luas 30,99 \%, 10 jenis pohon sesuai untuk fungsi penjerap partikel dengan luas 39,91\%, 11 jenis kurang sesuai untuk penjerap partikel dengan luas 21,37\%, dan 9 jenis tidak sesuai untuk penjerap partikel dengan luas $7,73 \%$.

5. Dari hasil penilaian dan evaluasi jalur hijau jalan diberikan rekomendasi fungsi RTH dalam menyerap polutan gas dan menjerap partikel. 


\subsection{Saran}

Saran yang diberikan berdasarkan hasil studi yang telah dilakukan sebagai berikut.

1. Hasil studi diharapkan dapat menjadi masukan bagi pengelola untuk pengembangan lanskap jalan yang selanjutnya pada kawasan Sentul City.

2. Penelitian ini diharapkan dapat menggambarkan pentingnya RTH untuk fungsi ekologis menyerap polutan gas dan menjerap partikel terutama pada lanskap jalan.

3. Dapat dilakukan penelitian lanjutan untuk mengetahui keefektifan penyerapan polutan gas dan penjerapan partikel pada jalan MH Thamrin. 


\section{DAFTAR PUSTAKA}

Anonim. 2009. Kota satelit. http://id.wikipedia.org/wiki/Kota_satelit. [03 Januari 2010]

Anonim. 2010. Satellite Town. http://en.wikipedia.org/wiki/Satellite_town. [26 Januari 2011]

Benson, JF dan Roe, MH. 2000. Landscape and Sustainability. London : Spon Press.

Branch, M C. 1995. Perencanaan Kota Komprehensif, Pengantar dan Penjelasan (Terjemahan). Yogyakarta : Gajah Mada University Press.

Carpenter, PL, TD Walker, FO Lanphear. 1975. Plants in the Landscape. San Fransisco : W.H.Freeman and Company.

Chiara, Joseph de dan Koppelman, Lee E. 1989. Standar Perencanaan Tapak (Site Planning Standards). Diterjemahkan oleh Januar Hakim. Jakarta : Penerbit Erlangga.

Dahlan, EN. 2004. Membangun Kota Kebun (Garden City) Bernuansa Hutan Kota. Bogor : IPB Press

Dahlan, EN. 1989. Studi Kemampuan Tanaman Dalam Menjerap dan Menyerap Timbal Emisi dari Kendaraan Bermotor [Tesis]. Fakultas Pascasarjana Institut Pertanian Bogor. Tidak dipublikasikan.

Direktorat Jenderal Penataan Ruang. 2006. Ruang Terbuka Hijau Sebagai Unsur Utama Tata Ruang Kota. Jakarta: Direktorat Jenderal Penataan Ruang, Departemen Penataan Pekerjaan Umum.

Direktorat Jenderal Bina Marga. 1996. Tata Cara Perencanaan Teknik Lanskap Jalan. Departemen Pekerjaan Umum.

Duryatmo, Sardi. 2008. Jasa Pohon Sepanjang Hayat. Trubus Edisi Khusus HUT Ke-63 RI.

Echols, John M dan Shadily, Hassan. 2000. Kamus Inggris - Indonesia. Jakarta : PT Gramedia. 
Ernawati, Sri Irene. 2003. Evaluasi Aspek Fungsi, Estetika, dan Agronomis Tanaman Tepi Jalan (Studi Kasus : Jalan Pajajaran, Kota Bogor, Jawa Barat) [Skripsi]. Jurusan Budi Daya Pertanian, Fakultas Pertanian, Institut Pertanian Bogor. Tidak dipublikasikan.

Fandeli, Chafid dan Muhammad. 2009. Prinsip-Prinsip Dasar Mengkonservasi Lanskap. Yogyakarta : UGM press.

Fardiaz, S. 1992. Polusi Air dan Udara. Yogyakarta : Kanisius

Frick, H dan FXB Suskiyanto. 2007. Dasar-Dasar Arsitektur Ekologis : Konsep Pembangunan Berkelanjutan dan Ramah Lingkungan. Yogyakarta : Kanisius.

Grey, GW dan FJ Deneke. 1978. Urban forestry. New York : John Wiley and Sons, Inc.

Handayani, Prastiti. 2000. Pelaksanaan Pekerjaan Lanskap Jalan Siliwangi Fase IV Dan V Kawasan Pemukiman Bukit Sentul Kabupaten Bogor, Propinsi Jawa Barat [Skripsi]. Jurusan Budi Daya Pertanian, Fakultas Pertanian, Institut Pertanian Bogor. Tidak dipublikasikan.

Harris, CW dan Dines, NT. 1988. Time-Saver Standards for Landscape Architecture : Design and Construction Data. USA : McGraw Hill Inc.

Harris, RW, JR Clark dan NP Matheny. 1999. Arboriculture. New Jersey : Prentice Hall, Inc.

Hidayat, IW. 2008. Evaluasi Jalur Hijau Jalan Sebagai Penyangga Lingkungan Sekitarnya dan Keselamatan Pengguna Jalan Bebas Hambatan Jagorawi [Tesis]. Program Pascasarjana Institut Pertanian Bogor. Tidak dipublikasikan.

Irianti, Efita Fitri. 2008. Perubahan Penggunaaan, Penutupan Lahan dan Ruang Terbuka Hijau Kota Bogor Tahun 1905-2005 [Skripsi]. Program Studi Arsitektur Lanskap Institut Pertanian Bogor. Tidak dipublikasikan.

Irwan, Zoer’aini Djamal. 2008. Tantangan Lingkungan dan Lansekap Hutan Kota. Jakarta : PT Bumi Aksara. 
Lab Perencanaan Lanskap Departemen Arsitektur Lanskap. 2005. Ruang Terbuka Hijau (RTH) Wilayah Perkotaan. www.google.com. [03 januari 2010]

Nasrullah, N, et al. 2001. Seleksi Tanaman Lanskap yang Berpotensi Tinggi Menyerap Polutan Gas $\mathrm{NO}_{2}$ dengan Menggunakan Gas $\mathrm{NO}_{2}$ Bertanda ${ }^{15} N$. Bulletin Taman dan Lanskap Indonesia Vol. 4/1/2001 : 1-5.

Newman, Peter and Jennings, Isabella. 2008. Cities as Sustainable Ecosystems : Principles and Practices. Washington : Island Press.

Odum, Eugene P. 1959. Fundamentals of Ecology. Phildelphia : W.B. Saunders Company.

Patra, Astra Dwi. 2002. Faktor Tanaman dan Faktor Lingkungan yang Mempengaruhi Kemampuan Tanaman Dalam Menyerap Polutan Gas $\mathrm{NO}_{2}$ [Tesis]. Program Pascasarjana Institut Pertanian Bogor.

Pemerintah Republik Indonesia. 2004. Undang-Undang Republik Indonesia Nomor 38 tahun 2004 tentang Jalan. Jakarta. 81 hal.

Pemerintah Republik Indonesia. 2009. Undang-Undang Republik Indonesia Nomor 22 tahun 2009 tentang Lalu Lintas dan Angkutan Jalan. Jakarta. 203 hal.

Pemerintah Republik Indonesia. 2007. Undang-Undang Republik Indonesia Nomor 26 tahun 2007 tentang Penataan Ruang. Jakarta. 107 hal.

Pemerintah Republik Indonesia. 1999. Peraturan Pemerintah Republik Indonesia Nomor 41 tahun 1999 tentang Pengendalian Pencemaran Udara. Jakarta. 34 hal.

Pemerintah Republik Indonesia. 2008. Peraturan Menteri Pekerjaan Umum Nomor 05 tahun 2008 tentang Pedoman Penyediaan dan Pemanfaaatan Ruang Terbuka Hijau di Kawasan Perkotaan. Jakarta. 34 hal

Prahasta, Eddy. 2002. Konsep-konsep Dasar Sistem Informasi Geografis. Informatika : Bandung.

PT Sentul City, Tbk. 2000. Analisis Dampak Lingkungan Pembangunan Perumahan Bukit Sentul. PT Sentul City, Tbk : Bogor.

PT Sentul City, Tbk. 2009. Pekerjaan Pemantauan RKL/RPL Pembangunan Kawasan Perumahan Sentul City. PT Sentul City, Tbk : Bogor. 
Roychansyah, M Sani. 2007. Machinami, Potret Pojok Kota. http://saniroy.archiplan.ugm.ac.id/index.php/2007/03/10/machinamipotret-pojok-kota/. [03 januari 2010]

Simonds, JO. 1978. Earthscape : A Manual of Environmental Planning. USA : McGraw Hill Inc.

Simonds, JO. 1983. Landscape Architecture. McGraw-Hill Book Company : New York.

Taihuttu, Hermina Neltje. 2001. Studi Kemampuan Tanaman Jalur Hijau Jalan Sebagai Penjerap Partikulat Hasil Emisi Kendaraan Bermotor [Tesis]. Program Pascasarjana Institut Pertanian Bogor. Tidak dipublikasikan.

Udayana, Cicik. 2004. Toleransi Spesies Pohon Tepi Jalan Terhadap Pencemaran Udara di Simpang Susun Jakarta (Jakarta Interchange) Cawang, Jaktim [Tesis]. Sekolah Pascasarjana Institut Pertanian Bogor. Tidak dipublikasikan.

Vitasari, Diana. 2004. Evaluasi Tata Hijau Jalan pada Tiga Jalan Kawasan Pemukiman Besar di Kabupaten Bogor, Jawa Barat [Skripsi]. Departemen Budidaya Pertanian, Fakultas Pertanian, Institut Pertanian Bogor. Tidak dipublikasikan.

Wardhana, Wisnu Arya. 2001. Dampak pencemaran lingkungan. Yogyakarta : Penerbit Andi.

Yang, $\mathrm{J}$ et al. 2005. The Urban Forest in Beijing and Its Role in Air Pollution Reduction. Urban For. Urban Green, 3 : 65-78. 
Lampiran 1 Jenis, letak dan jumlah pohon pada jalur hijau jalan MH Thamrin

\begin{tabular}{|c|c|c|c|c|c|c|}
\hline \multirow[b]{2}{*}{ No. } & \multirow[b]{2}{*}{ Nama latin } & \multirow[b]{2}{*}{ Nama lokal } & \multirow[b]{2}{*}{ Family } & \multicolumn{2}{|c|}{ Letak } & \multirow{2}{*}{$\begin{array}{r}\text { Jumlah } \\
\text { pohon }\end{array}$} \\
\hline & & & & Tepi & Median & \\
\hline 1. & Acacia mangium & Akasia mangium & Fabaceae & $\mathrm{v}$ & & 162 \\
\hline 2. & Araucaria heterophylla & Cemara norflok & Araucariaceae & $\mathrm{v}$ & & 197 \\
\hline 3. & Bauhinia blakeana & Bunga kupu-kupu & Fabaceae & $\mathrm{v}$ & $\mathrm{v}$ & 33 \\
\hline 4. & Bismarckia nobilis & Palem bismarck & Arecaceae & $\mathrm{v}$ & $\mathrm{v}$ & 154 \\
\hline 5. & Bucida molineti & Ketapang & Combretaceae & $\mathrm{v}$ & & 4 \\
\hline 6. & $\begin{array}{l}\text { Chrysalidocarpus } \\
\text { lutescens }\end{array}$ & Palem kuning & Arecaceae & & $\mathrm{v}$ & 91 \\
\hline 7. & Cocos nucifera & Kelapa & Arecaceae & $\mathrm{v}$ & & 102 \\
\hline 8. & Cordyline australis & Pandan bali & Laxmanniaceae & & $\mathrm{v}$ & 3 \\
\hline 9. & Dillenia philipinensis & Sempur & Dilleniaceae & $\mathrm{v}$ & & 1 \\
\hline 10. & Elaeis guineensis & Kelapa sawit & Arecaceae & $\mathrm{v}$ & $\mathrm{v}$ & 141 \\
\hline 11. & Erythrina cristagalli & Dadap merah & Papilionaceae & $\mathrm{v}$ & $\mathrm{v}$ & 92 \\
\hline 12. & Ficus benjamina & Beringin & Moraceae & $\mathrm{v}$ & & 20 \\
\hline 13. & Ficus lyrata & Biola cantik & Moraceae & $\mathrm{v}$ & & 2 \\
\hline 14. & Ficus sp. & Beringin & Moraceae & $\mathrm{v}$ & & 13 \\
\hline 15. & Filicium decipiens & Kerai payung & Sapindaceae & $\mathrm{v}$ & & 1 \\
\hline 16. & Gmelina arborea & Jati putih & Verbenaceae & $\mathrm{v}$ & & 42 \\
\hline 17. & Livistona rotundifolia & Palem sadeng & Arecaceae & $\mathrm{v}$ & $\mathrm{v}$ & 83 \\
\hline 18. & Pandanus sp & Pandan hijau & Pandanaceae & $\mathrm{v}$ & & 2 \\
\hline 19. & Pandanus utilis & Pandan melintir & Pandanaceae & $\mathrm{v}$ & $\mathrm{v}$ & 4 \\
\hline 20. & $\begin{array}{l}\text { Paraserianthes } \\
\text { falcataria }\end{array}$ & Sengon & Mimosaceae & $\mathrm{v}$ & & 29 \\
\hline 21. & Phoenix roebelenii & Phoenix & Areaceae & & $\mathrm{v}$ & 72 \\
\hline 22. & Pinus merkusii & Pinus & Pinaceae & $\mathrm{v}$ & & 463 \\
\hline 23. & Plumeria rubra & Kamboja & Apocynaceae & & $\mathrm{v}$ & 70 \\
\hline 24. & $\begin{array}{l}\text { Ravenala } \\
\text { madagascariensis }\end{array}$ & Pisang kipas & Strelitziaceae & $\mathrm{v}$ & & 2 \\
\hline 25. & Roystonea regia & Palem raja & Arecaceae & $\mathrm{v}$ & & 12 \\
\hline 26. & Salix babylonica & Salix/liang liu & Salicaceae & $\mathrm{v}$ & & 6 \\
\hline 27. & Samanea saman & Saman & Fabaceae & $\mathrm{v}$ & $\mathrm{v}$ & 48 \\
\hline 28. & Schefflera actinophylla & Walisongo & Araliaceae & $\mathrm{v}$ & & 1 \\
\hline 29. & Spatodhea campanulata & Kecrutan & Bignoniaceae & $\mathrm{v}$ & & 2 \\
\hline 30. & Tectona grandis & Jati & Verbenaceae & $\mathrm{v}$ & & 5 \\
\hline 31. & Veitchia merilii & Palem putri & Arecaceae & & $\mathrm{v}$ & 24 \\
\hline 32. & Wodyetia bifurcata & Palem ekor tupai & Arecaceae & $\mathrm{v}$ & & 8 \\
\hline Total & & & & & & 1889 \\
\hline
\end{tabular}


Lampiran 2 Elemen tanaman pada jalur hijau jalan MH Thamrin

\begin{tabular}{|c|c|c|c|c|}
\hline No. & Nama lokal & Nama latin & Family & Jenis \\
\hline \multicolumn{5}{|l|}{ Pohon } \\
\hline \multicolumn{5}{|c|}{ Groundcover } \\
\hline 1. & Kacang-kacangan & Arachis pintoi & Leguminaceae & Groundcover \\
\hline 2. & Nanas hias & Bromelia sp. & Bromeliaceae & Groundcover \\
\hline 3. & Cabai & Capsicum аппиит & Solanaceae & Groundcover \\
\hline 4. & Lili paris & Chlorophytum comosum & Liliacaeae & Groundcover \\
\hline 5. & Ilalang putih & Imperata cylindrica & Poaceae & Groundcover \\
\hline 6. & Bayam merah & Iresine herbstii & Amarantaceae & Groundcover \\
\hline 7. & Lantana & Lantana camara & Verbenaceae & Groundcover \\
\hline 8. & $\begin{array}{l}\text { Paku jejer } \\
\text { Opiopogon }\end{array}$ & Nephrolepis sp. & Oleandraceae & Groundcover \\
\hline 9. & variegata & Ophiopogon jaburan & Liliacaeae & Groundcover \\
\hline 10. & Opiopogon & Ophiopogon sp. & Liliacaeae & Groundcover \\
\hline 11. & Pandan variegata & $\begin{array}{l}\text { Pandanus pygmaeus } \\
\text { Ruellia malacosperma }\end{array}$ & Pandanaceae & Groundcover \\
\hline 12. & Ruellia & $d w a r f$ & Acanthaceae & Groundcover \\
\hline 13. & Bawang brojol & Zephyrantes sp. & Liliacaeae & Groundcover \\
\hline \multicolumn{5}{|c|}{ Semak } \\
\hline 1. & Akalipa hijau & Acalypha wilkesiana & Euphorbiaceae & Semak sedang \\
\hline 2. & Agave & Agave angustifolia & Agavaceae & Semak rendah \\
\hline 3. & Siklok & Agave attenuata & Agavaceae & Semak rendah \\
\hline 4. & Talas-talasan & Alocasia macrorrhiza & Araceae & Semak sedang \\
\hline 5. & Bambu & Arundinaria pumila & Poaceae & Semak tinggi \\
\hline 6. & Bougenvil ungu & Bougenvillea $s p$ & Nyctaginaceae & Semak tinggi \\
\hline 7. & Bunga tasbih & $\begin{array}{l}\text { Canna sp. } \\
\text { Crossandra }\end{array}$ & Cannaceae & Semak rendah \\
\hline 8. & Krosandra & infundibuliformis & Acanthaceae & Semak rendah \\
\hline 9. & Honje & Etlingera hemisphaerica & Zingiberaceae & Semak tinggi \\
\hline 10. & False agave & Furcraea gigantea & Amaryllidaceae & Semak rendah \\
\hline 11. & Kembang sepatu & Hibiscus $s p$. & malvaceae & Semak tinggi \\
\hline 12. & Spider lily & Hymenocallis speciosa & Amaryllidaceae & Semak rendah \\
\hline 13. & Soka & Ixora sp. & Rubiaceae & Semak rendah \\
\hline 14. & Yellow walking iris & Neomarica longifolia & Iridaceae & Semak rendah \\
\hline 15. & Patah tulang & Pedilanthus tithymaloides & Euphorbiaceae & Semak rendah \\
\hline 16. & Palem wregu & Rhapis excelsa & Arecaceae & Semak sedang \\
\hline 17. & Air mancur & Russelia equisetiformis & Scrophulariaceae & Semak sedang \\
\hline \multicolumn{5}{|l|}{ Perdu } \\
\hline 1. & Kembang merak & Caesalpinia pulcherrima & Fabaceae & Perdu tinggi \\
\hline & Puring & Codiaeum sp. & Euphorbiaceae & Perdu rendah \\
\hline 3. & Hanjuang & $\begin{array}{l}\text { Cordyline sp. } \\
\text { Dracaena reflexa }\end{array}$ & Agavaceae & Perdu tinggi \\
\hline & Drasena & $\begin{array}{l}\text { variegate } \\
\text { Dracaena sanderiana }\end{array}$ & Agavaceae & Perdu tinggi \\
\hline 5. & Drasena & cultivar & Agavaceae & Perdu tinggi \\
\hline 6. & Kastuba & Euphorbia pulcherrima & Euphorbiaceae & Perdu tinggi \\
\hline 7. & Helikonia & Heliconia $s p$ & Strelitziaceae & Perdu rendah \\
\hline 8. & Nusa indah putih & Mussaenda alba & Rubiaceae & Perdu tinggi \\
\hline 9. & Nusa indah & Mussaenda sp. & Rubiaceae & Perdu tinggi \\
\hline
\end{tabular}




\begin{tabular}{|c|c|c|c|c|}
\hline 10. & Melati jepang & $\begin{array}{l}\text { Nerium oleander } \\
\text { Pseuderanthemum } \\
\text { reticulatum }\end{array}$ & $\begin{array}{l}\text { Apocynaceae } \\
\text { Acanthaceae }\end{array}$ & $\begin{array}{l}\text { Perdu tinggi } \\
\text { Perdu rendah }\end{array}$ \\
\hline \multicolumn{5}{|c|}{ Rumput } \\
\hline 1. & Rumput gajah & Ахопориs compressus & Poaceae & Rumput \\
\hline 2. & Rumput kawat & Cynodon dactylon & Poaceae & Rumput \\
\hline \multicolumn{5}{|c|}{ Tanaman merambat } \\
\hline 1. & Alamanda kuning & Alamanda cathartica & Apocynaceae & Tanaman rambat \\
\hline 2. & Alamanda putih & Alamanda sp & Apocynaceae & Tanaman rambat \\
\hline 3. & Bougenvil ungu & Bougenvillea $s p$ & Nyctaginaceae & Tanaman rambat \\
\hline 4. & Bougenvil orange & Bougenvillea spectabilis & Nyctaginaceae & Tanaman rambat \\
\hline 5. & Sirih & Epipremnum pinnatum & Araceae & Tanaman rambat \\
\hline 6. & Monstera & Monstera sp. & Araceae & Tanaman rambat \\
\hline 7. & Pasiflora & Passiflora sp. & Passifloraceae & Tanaman rambat \\
\hline 8. & Sirih & Piper betle & Pioeraceae & Tanaman rambat \\
\hline 9. & Sirih belanda & Scindapsus aureus & Araceae & Tanaman rambat \\
\hline 10. & Singonium & Syngonium podophyllum & Araceae & Tanaman rambat \\
\hline \multicolumn{5}{|c|}{ Tanaman air } \\
\hline 1. & Umbrella grass & Cyperus sp & Cyperaceae & Tanaman air \\
\hline 2. & Mendong & Fimbristylis globulosa & Cyperaceae & Tanaman air \\
\hline 3. & Teratai & Nymphaea lotus & Nymphaceae & Tanaman air \\
\hline 4. & Kana air & Thalia dealbata & Maranthaceae & Tanaman air \\
\hline
\end{tabular}

Sumber : Survey lapang 
Lampiran 3 Data AMDAL kualitas udara Sentul City tahun 2009

\begin{tabular}{cccccccc}
\hline \multirow{2}{*}{ No } & \multirow{2}{*}{ Parameter } & Satuan & $\mathrm{U} 1$ & $\mathrm{U} 2$ & $\mathrm{U} 3$ & $\mathrm{U} 4$ & \multirow{2}{*}{ Baku mutu } \\
\cline { 4 - 7 } 1 & $\mathrm{NO}_{2}$ & $\mu \mathrm{g} / \mathrm{Nm}^{3}$ & 5.8 & 5.92 & 5.54 & 5.5 & $400^{*}$ \\
\hline 2 & $\mathrm{SO}_{2}$ & $\mu \mathrm{g} / \mathrm{Nm}^{3}$ & 110.19 & 119.49 & 131.01 & 108.18 & $900^{*}$ \\
\hline 3 & $\mathrm{CO}$ & $\mu \mathrm{g} / \mathrm{Nm}^{3}$ & 145.7 & 140.4 & 140.4 & 227.4 & $30000^{*}$ \\
\hline 4 & $\mathrm{O}_{3}$ & $\mu \mathrm{g} / \mathrm{Nm}^{3}$ & 1.98 & 2.04 & 0.76 & 0.55 & $235^{*}$ \\
\hline 5 & $\mathrm{~Pb}$ & $\mu \mathrm{g} / \mathrm{Nm}^{3}$ & 0.05 & 0.05 & 0.05 & 0.1 & $2 *$ \\
\hline 6 & $\mathrm{Debu}$ & $\mu \mathrm{g} / \mathrm{Nm}^{3}$ & 19.75 & 20.16 & 32.49 & 35.48 & $230^{*}$ \\
\hline 7 & $\mathrm{H}$ & $\mathrm{ppm}$ & $<0.005$ & $<0.005$ & $<0.005$ & $<0.005$ & $0.02^{* *}$ \\
\hline 8 & $\mathrm{NH}_{3}$ & $\mathrm{ppm}$ & $<0.1$ & 0.01 & $<0.01$ & $<0.01$ & $2 *$
\end{tabular}

Sumber : Pekerjaan pemantauan RKL/RPL Pembangunan Kawasan Perumahan Sentul City(2009).

* $\quad$ Baku mutu kualitas udara ambient $\left(\mathrm{NO}_{2}, \mathrm{SO}_{2}, \mathrm{CO}, \mathrm{O}_{3}, \mathrm{~Pb}\right.$, Debu) berdasarkan Peraturan Pemerintah Republik Indonesia No 41 Tahun 1999

** $\quad$ Baku mutu kualitas udara ambient $\left(\mathrm{H}_{2} \mathrm{~S}\right.$ dan $\left.\mathrm{NH}_{3}\right)$ berdasarkan Keputusan Menteri lingkungan hidup KEP-50/MENLH/11/1996

Lokasi

U1 : akses tol depan mall/area komersial Bellanova, Jl MH Thamrin

U2 : akses masuk Kp Pasir Maung/ke kantor kecamatan

U3 : bagian depan Perumahan Mediterania

U4 : akses Kp Banceuy 
Lampiran 4 Jenis tanaman yang berpotensi menyerap $\mathrm{NO}_{2}$

\begin{tabular}{|c|c|c|c|}
\hline No. & Nama latin & Nama lokal & Serapan ${ }^{15} \mathrm{~N}(\mu \mathrm{g} / \mathrm{gr})$ \\
\hline \multicolumn{4}{|l|}{ Pohon } \\
\hline A. & Serapan tinggi (> $30 \mu \mathrm{g} / \mathrm{gr}$ ) & & \\
\hline 1. & Erythrina variegata & Dadap kuning & 68.31 \\
\hline 2. & Cananga odorata & Kenanga & 46.70 \\
\hline 3. & Gnetum gnemon & Melinjo & 44.17 \\
\hline 4. & Calliandra surinamensis & Kaliandra & 41.01 \\
\hline 5. & Delonix regia & Flamboyant & 38.58 \\
\hline 6. & Caesalpinia pulcherrima & Kembang merak & 36.99 \\
\hline 7. & Diallium indum & Asam kranji & 36.69 \\
\hline 8. & Ceiba pentandra & Kapuk & 35.66 \\
\hline 9. & Bixa orellana & Galinggem & 35.56 \\
\hline 10. & Brownea capitella & Bunga lampion & 35.39 \\
\hline 11. & Samanea saman & Kihujan & 35.37 \\
\hline 12. & Michelia campaka & Cempaka & 33.92 \\
\hline 13. & Psidium guajava & Jambu biji & 30.80 \\
\hline 14. & Cassia multijuga & Hujan mas & 30.52 \\
\hline 15. & Artocarpus integra & Nangka & 30.35 \\
\hline B. & Serapan sedang (15-30 $\mu \mathrm{g} / \mathrm{gr})$ & & \\
\hline 1. & Casuarina equisetifolia & Cemara angin & 28.79 \\
\hline 2 & Khaya senegalensis & Pohon kaya & 28.61 \\
\hline 3. & Terminalia catappa & Ketapang & 27.02 \\
\hline 4. & Spathodea campanulata & Kecrutan & 26.88 \\
\hline 5. & Bauhinia purpurea & Bunga kupu-kupu & 26.30 \\
\hline 6. & Pterocarpus indicus & Angsana & 25.44 \\
\hline 7. & Arundinaria sp. & Bambu jepang & 25.33 \\
\hline 8. & Mangifera indica & Mangga & 25.12 \\
\hline 9. & Saraca indica & Asoka & 23.94 \\
\hline 10. & Eucalyptus alba & Kayu putih & 23.65 \\
\hline 11. & Cassia biflora & Kasia golden & 22.85 \\
\hline 12. & Areca cathecu & Pinang jambe & 22.62 \\
\hline 13. & Cassia sp. & Ayoga & 21.91 \\
\hline 14. & Barringtonia asiatica & Keben & 21.10 \\
\hline 15. & Lansium domesticum & Duku & 20.28 \\
\hline 16. & Polyaltia fragrans & Glodogan bulat & 20.15 \\
\hline 17. & Mangifera caesia & Kemang & 19.72 \\
\hline 18. & Cinnamomum burmanii & Kayu manis merah & 19.71 \\
\hline 19. & Caryota mitis & Palm ekor ikan & 18.89 \\
\hline 20. & Veitchia merilii & Palem putri & 18.66 \\
\hline 21. & Elaeis guineensis & Kelapa sawit & 17.81 \\
\hline 22. & Casuarina sumatrana & Cemara balon & 17.71 \\
\hline 23. & Schefflera actinophylla & Wali songo & 16.87 \\
\hline 24. & Mimusoph elengi & Tanjung & 16.41 \\
\hline 25. & Cocos nucifera capitata & Kelapa gading & 16.41 \\
\hline C. & Serapan rendah $(<15 \mu g / g r)$ & & \\
\hline 1. & Agathis dammara & Damar & 14.84 \\
\hline 2. & Cocos nucifera & Kelapa & 14.48 \\
\hline 3. & Durio zibetinus & Durian & 14.49 \\
\hline 4. & Cinnamomum zeylanicum & Kayu manis hijau & 13.06 \\
\hline 5. & Juniperus sinensis & Cemara tiang & 13.06 \\
\hline 6. & Nephelium lappaceum & Rambutan & 12.44 \\
\hline
\end{tabular}


7.

Nephelium longanum

10.

11.

12.

13

14.

15.

16.

17.

18.

19.

20.

21.

22.

23.

24.

25.

26.

27.

28.

29.

30.

31.

32.

A. $\quad$ Serapan tinggi ( $>30 \mu g / g r)$

1.

2.

3.

4.

5.

6.

7.

8.

9.

10.

11.

12.

13.

B.

1.

2.

3.

4.

5.

6.

7.

8.

9.

10.

11.

12.

13.

14.

15.

16.
Laucaena glauca

Roystonea regia

Dillenia philipinensis

Livistona rotundifolia

Ficus benjamina

Cassia siamea

Ficus elastic

Podocarpus nerifolius

Shorea leprosula

Myristica fragrans

Cyrtostachis lakka

Cupressus papuana

Cyanometra cauliflora

Canarium communae

Lagerstromia loudonii

Manilkara kauki

Phyllostachys sulphurea

Araucaria excelsa

Mascarena lagenicaulis

Polyaltia longifolia

Felicium decipiens

Phyticosperma macarthurii

Thuja orientalis

Acacia mangium

Acalypha wilkesiana

Serapan sedang (15-30 $\mathrm{\mu g} / \mathrm{gr})$

Scindapsus aureus

Alpinia purpurata

Ixora javanica

Notophanax sarcofagus
Akasia

12.39

Lengkeng $\quad 12.35$

Lamtoro

12.20

Palem raja $\quad 11.74$

Sempur $\quad 11.03$

Palem sadeng $\quad 10.60$

Beringin $\quad 9.63$

Johar $\quad 8.82$

Beringin karet $\quad 8.62$

Kiputri $\quad 8.62$

Meranti $\quad 8.26$

Pala $\quad 8.10$

Palm merah $\quad 7.97$

Cemara papua $\quad 7.80$

Nam-nam $\quad 7.31$

Kenari 6.21

Bungur 6.13

Sawo kecik $\quad 5.18$

Bambu kuning $\quad 5.11$

Cemara norflok $\quad 4.76$

Palem botol $\quad 4.38$

Glodogan tiang $\quad 3.61$

Kerai paying $\quad 3.46$

Palem hijau $\quad 2.81$

Cemara kipas $\quad 1.44$

$\begin{array}{ll}\text { Cemara kipas } & 1.44 \\ \text { Akasia mangium } & 0.28\end{array}$

$\begin{array}{lc}\text { Lollipop merah } & 100.02 \\ \text { Kihujan } & 93.28\end{array}$

$\begin{array}{ll}\text { Kihujan } & 93.28 \\ \text { Akalipa merah } & 64.80\end{array}$

Lollipop kuning $\quad 61.70$

Nusa indah merah $\quad 53.53$

Daun mangkokan $\quad 46.07$

Bogenvil merah $\quad 45.44$

Kaca piring $\quad 45.29$

Miana $\quad 41.70$

Hanjuang merah $\quad 36.34$

Azalea $\quad 35.95$

Lantana ungu $\quad 35.14$

Akalipa hijau-putih $\quad 31.24$

Lengkuas merah

25.63

24.55

Ixora daun besar $\quad 23.86$

Kedondong laut $\quad 20.95$

Bakung 20.03

Bunga mentega $\quad 20.03$

Palem kuning $\quad 19.48$

Kana $\quad 18.91$

Bayam merah $\quad 18.86$

Keladi putih $\quad 18.50$

Drasena $\quad 17.74$

Alamanda $\quad 17.63$

Bunga pukul empat $\quad 17.51$

Helikonia merah $\quad 18.86$

Beluntas $\quad 16.99$

Sikas 16.28 


\begin{tabular}{|c|c|c|c|}
\hline 17. & Gendarusa vulgaris & Gendarusa & 16.27 \\
\hline 18. & Arundinaria pumila & Bambu pangkas & 15.97 \\
\hline 19. & Costus speciosus & Pacing & 15.27 \\
\hline 20. & Acalypha macrophylla & Teh-tehan & 15.10 \\
\hline C. & \multicolumn{3}{|c|}{ Serapan rendah $(<15 \mu \mathrm{g} / \mathrm{gr})$} \\
\hline 1. & Carmona retusa & Serut & 13.67 \\
\hline 2. & Heliconia sp. & Helikonia oranye & 13.60 \\
\hline 3. & Clerodendron thomsonae & Nona makan sirih & 13.58 \\
\hline 4. & Vinca rosea & Tapak dara & 12.41 \\
\hline 5. & Plumbago indica & Plumbago & 12.39 \\
\hline 6. & Licuala grandis & Palem kol & 11.93 \\
\hline 7. & Ficus repens & Dolar-doalran & 11.76 \\
\hline 8. & Mussaendah alba & Nusa indah putih & 10.90 \\
\hline 9. & Agave sisalana & Agave hijau & 9.99 \\
\hline 10. & Pleomele variegata & Pleomele & 8.56 \\
\hline 11. & Passiflora cocinea & Passiflora & 8.46 \\
\hline 12. & Bougainvillea spectabilis & Bougenvil oranye & 7.89 \\
\hline 13. & Hippeastrum amarylis & Amarilis & 7.71 \\
\hline 14. & Agave americana & Agave kuning & 7.61 \\
\hline 15. & Aglaonema nitidum & Sri rejeki & 7.59 \\
\hline 16. & Caladium bicolor & Keladi hias & 7.47 \\
\hline 17. & Stephanotis floribunda & Stepanot & 7.44 \\
\hline 18. & Heliconia rosrata & Pisang hias & 6.83 \\
\hline 19. & Rosa chinensis & Mawar & 6.60 \\
\hline 20 & Cycas rumphii & Pakis haji & 6.22 \\
\hline 21. & Malphigia coccigyera & Mirten & 5.53 \\
\hline 22. & Duranta repens & Duranta kuning & 4.48 \\
\hline 23. & Excoecaria bicolor & Sambang darah & 4.77 \\
\hline 24. & Murraya paniculata & Kemuning & 4.56 \\
\hline 25. & Salvia splendens & Salvia merah & 4.23 \\
\hline 26. & Duranta variegata & Terang bulan & 4.11 \\
\hline 27. & Ixora chinensis & Ixora daun kecil & 4.11 \\
\hline 28. & Rhapis excelsa & Palem wregu & 3.40 \\
\hline 29. & Phyllanthus niruri & Cendrawasih & 2.57 \\
\hline 30. & Hibiscus rosa-sinensis & Kembang sepatu & 2.03 \\
\hline 31. & Eugenia uniflora & Sianto & 1.97 \\
\hline \multicolumn{4}{|c|}{ Rumput } \\
\hline A. & \multicolumn{3}{|c|}{ Serapan sedang (15-30 $\mu \mathrm{g} / \mathrm{gr})$} \\
\hline 1. & Alternanthera ficoides & Kriminil merah & 24.06 \\
\hline 2. & Zoysia matrella & Rumput manila & 22.58 \\
\hline 3. & Rhoeo discolor & Adam hawa & 18.81 \\
\hline B. & \multicolumn{3}{|c|}{ Serapan rendah $(<15 \mu \mathrm{g} / \mathrm{gr})$} \\
\hline 1. & Cynodon dactylon & Rumput kawat & 13.94 \\
\hline 2. & Axonopus compressus & Rumput paetan & 13.31 \\
\hline 3. & Althernantera amoena & Kriminil putih & 9.96 \\
\hline 4. & Cuphea macrophylla & Taiwan beauty & 9.72 \\
\hline 5. & Chlorophytum comosum & Clorophytum hijau & 9.50 \\
\hline 6. & Philea cardierei & Mutiara & 7.13 \\
\hline 7. & Chlorophytum bachestii & Chlorophytum putih & 4.56 \\
\hline 8. & Ophiopogon jaburan & Lili paris putih & 2.38 \\
\hline
\end{tabular}

Sumber : Nizar Nasrullah, et al. 2001. Seleksi Tanaman Lanskap yang Berpotensi Tinggi Menyerap Polutan Gas $\mathrm{NO}_{2}$ dengan Menggunakan Gas $\mathrm{NO}_{2}$ Bertanda ${ }^{15} \mathrm{~N}$. Dalam Bulletin Taman Dan Lanskap Indonesia Vol. 4/1/2001. 
Lampiran 5 Daya serap pohon terhadap karbondioksida

\begin{tabular}{|c|c|c|c|c|}
\hline No. & Nama lokal & Nama ilmiah & $\begin{array}{c}\text { Daya serap } \mathrm{CO}_{2} \\
\text { (kg/pohon/thn) }\end{array}$ & $\begin{array}{l}\text { Tingkat } \\
\text { serapan }\end{array}$ \\
\hline 1 & Trembesi & Samanea saman & $28.488,39$ & Sangat tinggi \\
\hline 2 & Cassia & Cassia sp. & $5.295,47$ & Sangat tinggi \\
\hline 3 & Kenanga & Canagium odoratum & 756,59 & Tinggi \\
\hline 4 & Pingku & Dysoxylum excelsum & 720,49 & Tinggi \\
\hline 5 & Beringin & Ficus benjamina & 535,90 & Tinggi \\
\hline 6 & Kerai payung & Felicium decipiens & 404,83 & Agak tinggi \\
\hline 7 & Matoa & Pometia pinnata & 329,76 & Agak tinggi \\
\hline 8 & Mahoni & Swietenia mahoganii & 295,73 & Agak tinggi \\
\hline 9 & Saga & Adenanthera pavonina & 221,18 & Agak tinggi \\
\hline 10 & Bungur & Lagerstromia speciosa & 160,14 & Agak tinggi \\
\hline 11 & Jati & Tectona grandis & 135,27 & Sedang \\
\hline 12 & Nangka & Arthocarpus heterophyllus & 126,51 & Sedang \\
\hline 13 & Johar & Cassia grandis & 116,25 & Sedang \\
\hline 14 & Sirsak & Annona muricata & 75,29 & Sedang \\
\hline 15 & Puspa & Schima wallichii & 63,31 & Sedang \\
\hline 16 & Akasia & Acacia auriculiformis & 48,68 & Sedang \\
\hline 17 & Flamboyant & Delonix regia & 42,20 & Rendah \\
\hline 18 & Sawo kecik & Manilkara kauki & 36,19 & Rendah \\
\hline 19 & Tanjung & Mimusoph elengi & 34,29 & Rendah \\
\hline 20 & Bunga merak & Caesalpinia pulcherrima & 30,95 & Rendah \\
\hline 21 & Sempur & Dillenia retusa & 24,24 & Rendah \\
\hline 22 & Khaya & Khaya anthotheca & 21,90 & Rendah \\
\hline 23 & Merbau pantai & Intsia bijuga & 19,25 & Rendah \\
\hline 24 & Akasia & Acacia mangium & 15,19 & Rendah \\
\hline 25 & Angsana & Pterocarpus indicus & 11,12 & Sangat rendah \\
\hline 26 & Asam kranji & Pithecelobium dulce & 8,48 & Sangat rendah \\
\hline 27 & Saputangan & Maniltoa grandiflora & 8,26 & Sangat rendah \\
\hline 28 & Dadap merah & Erythrina cristagalli & 4,55 & Sangat rendah \\
\hline 29 & Rambutan & Nephelium lappaceum & 2,19 & Sangat rendah \\
\hline 30 & Asam & Tamarindus indica & 1,49 & Sangat rendah \\
\hline 31 & Kempas & Coompasia excelsa & 0,20 & Sangat rendah \\
\hline
\end{tabular}

Sumber : Duryatmo, Sardi. 2008. Jasa Pohon Sepanjang Hayat. Trubus Edisi Khusus HUT Ke-63 RI. 